\title{
Investigation of Students' Cognitive Learning in Mathematics Lessons Supported with Writing Activities
}

\author{
Ercan Atasoy ${ }^{a}$ and Adnan Baki ${ }^{b}$ \\ ${ }^{a}$ Recep Tayyip Erdogan University, Faculty of Education, Rize/Turkey (ORCID: 0000-0003-4613-6950) \\ ${ }^{\mathbf{b}}$ Trabzon University, Fatih Faculty of Education, Trabzon/Turkey (ORCID: 0000-0002-1331-053X)
}

Article History: Received: 13 March 2020; Accepted: 5 August 2020; Published online: 28 August 2020

\begin{abstract}
The aim of the present research was to examine the contribution of expository and journal writing activities to the cognitive development of 7 th-grade students with varying levels of academic achievement in mathematics education. The qualitative research approach has been adopted in this research. The lessons were conducted in one 7 th grade class of 28 students using a total of 26 expository writing activities and 6 journal writings designed to address the topics of "lines, angles and measuring angles, operations with integers, rational numbers, algebraic expressions, equations, ratio and proportion." During the 14 weeks of lessons, three themes were created and various codes were established under these themes by means of content analysis of the written explanations obtained from students' expository writing activities and diaries. In addition, the expository writing activities were analyzed using an analytical scoring rubric (ASR). The findings were coded under three themes: (1) features of the students' explanations (2) use of mathematical language and (3) mathematical algorithms and calculations. According to the data obtained, it has been determined that writing activities contribute to the cognitive development of particularly those students with a moderate level of academic achievement. In addition, it was revealed that the responses provided in writing activities by students with different levels of academic achievement varied. Based on the results of the study, it is recommended that writing activities be implemented over a long and continuous period of time.
\end{abstract}

Keywords: Expository writing, journal writing, cognitive learning

DOI:10.16949/turkbilmat.703648

\begin{abstract}
Öz: Araştırmanın amacı, açıklayıcı ve günlük yazma uygulamalarının farklı akademik başarıya sahip 7. sınıf öğrencilerinin, matematikteki bilişsel öğrenmelerine katkısını incelemektir. Araştırmada nitel araştırma yaklaşımı benimsenmiştir. Dersler 28 öğrenciden oluşan bir 7. sınıfta 'doğrular, açılar ve açıları ölçme, tam sayılarla işlemler, rasyonel sayılar, cebirsel ifadeler, denklemler, oran ve orantı' konularında hazırlanmış toplam 26 açıklayıcı yazma etkinliği ve 6 günlük yazma etkinliği kullanılarak yürütülmüştür. 14 hafta süren derslerde öğrencilerin açıklayıcı yazma etkinliklerinden ve günlüklerinden elde edilen yazılı açıklamalara içerik analizi yapılarak üç tema ve bu tema altında kodlar oluşturulmuştur. Ayrıca açıklayıcı yazma etkinlikleri analitik dereceli puanlama anahtarı (ADPA) kullanılarak analiz edilmiştir. Ayrıca bulgular; (1) öğrencilerin yaptıkları açıklamaların özellikleri, (2) matematiksel dili kullanma ve (3) matematiksel algoritma ve hesaplamalar olmak üzere üç tema altında kodlanarak sunulmuştur. Elde edilen verilere göre, yazma uygulamalarının özellikle başarı seviyesi orta olan öğrencilerin bilişsel gelişimine katkı sağladığı belirlenmiştir. Ayrıca farklı akademik başarı seviyesindeki öğrencilerin yazma uygulamalarına verdikleri cevapların da farklılık gösterdiği tespit edilmiştir. Araştırmanın sonuçlarına göre, yazma uygulamalarının uzun bir zaman dilimine yayılarak ve sürekli olarak kullanılması önerilmektedir.
\end{abstract}

Anahtar Kelimeler: Açıklayıcı yazma, günlük yazma, bilişsel öğrenme

Türkçe sürüm için tıklayınız

\section{Introduction}

Mathematics, which does not strictly correspond to daily language, is a universal language that has concepts, terminologies, symbols and words peculiar to itself (Hoffert, 2009). Speaking, listening, reading, and writing are among the elements of language (Shanahan, 2006). Speaking and writing serve an important function while learning a language (Güneş, 2013). As mathematics is also a language, the role of speaking and writing in understanding, interpreting and activating thoughts in mathematics is important (Baki, 2008). It is stated that one of the methods students use during the self-construction process of mathematical knowledge and more effective learning and internalization of concepts is mutually speaking and writing the mathematical language (Albert, 2000; Pugalee, 2004). However, since the act of writing requires simultaneous usage of the hand, eye, and the brain, it necessitates more effort when compared to the other language skills (Demir, 2013).

Since writing and mathematics are considered independent of each other in traditional mathematics teaching, using the writing skill in mathematics lessons can be regarded as extraordinary (Liedtke \& Sales, 2001). In fact, while writing is identified with Turkish lessons, calculations are identified with mathematics lessons (Reilly,

* This article is derived from first author's doctorate dissertation entitled "The Examination of Writing Based Activities in Mathematics from the Perspectives of Learning and Teaching\| conducted under the supervision of the second author.

Citation Information: Atasoy, E. \& Baki, A. (2020). Investigation of students' cognitive learning in mathematics lessons supported with writing activities. Turkish Journal of Computer and Mathematics Education, 11(2), 528-583. 
2007). Thus, the process of using writing activities in mathematics lessons has not undergone rapid progression (Her-rick, 2005). Applebee and Langer (2006) stated that writing activities were more often used in sciences and social sciences courses, but much less in mathematics lessons. In a study by Yalvaç (2019), in which the ability to use mathematical language in the domain of algebra was examined, it was revealed that students' use of mathematical language was not at a satisfactory level. Yet numerous studies advocate the use of writing activities in the mathematics curriculum (Gibson \& Thomas, 2005; Meier \& Rishel, 1998; Ntenza, 2006; O’Connel et al., 2005; Pugalee, 2004).

The project titled 'Writing Across the Curriculum [WAC]', which started in the U.S.A and England at the end of the 1960s and then spread to Canada and Latin America, aimed for the use of write-to-learn activities not only in English lessons but in other subjects as well (Uğurel, Tekin, Yavuz \& Keçeli, 2009; Keathley, 2018). Even though the WAC movement was found to be successful, some problems were claimed to have emerged in its propogation. First of all, the fact that some mathematics topics are conducive to writing, while others are not leads teachers to the idea that they can utilize writing only in narrated problems. Secondly, the idea that this kind of informal writing where imperfect sentence algorithms can be used for formal communication disturbs some teachers. Thirdly, its implementation in crowded classes is difficult (Fulwiler, 1984). Despite all these difficulties, it was suggested in the U.S.A. that writing activities be used across all grade levels (National Council of Teachers of Mathematics [NCTM], 1989). From the 1960s to the current time, many researchers have asserted that writing about a certain topic supports the learning of that topic (Galbraith \& Baaijen, 2018). This assertion has led to the use of such genres of writing as expository, journal, and free writing in various disciplines as sciences, social sciences, and mathematics for learning purposes (Smagorinsky \& Mayer, 2014). However, Smagorinsky (1995) stated that there are subjects where writing does not have any impact on learning.

Writing to learn in mathematics curriculums was first mentioned at the end of the 1960s. After the 1980s, writing to learn started to be used as a method of communication and learning (Johnson \& Holcombe, 1993; Nagin \& National Writing Project, 2003). In the national curricula of many countries in the 1990s (in England and Wales in 1995, in Australia in 1990, in South Africa in 2002), making more use of oral and written language instead of mathematical symbolism was encouraged (Ntenza, 2006). In the national mathematics curriculum in Turkey, which started to be implemented in the year 2005 and was revised in the years 2009, 2015, and 2017, communication is one of the basic skills that is aimed to be developed in students. For the development of the communication skill, writing about mathematics is regarded as an important activity (Pugalee, 2001). Accordingly, it is briefly noted in education curriculums that students could be required to produce written explanations of what a rule regarding a problem solution means and to keep a journal for measurement and assessment purposes (Ministry of National Education [MoNE], 2007). However, it is observed with reference to the 2018 education curriculum that there is no sufficient explanation about how writing activities could be implemented.

Even though writing-to-learn has been incorporated into the education curriculums across all levels of education, Günel (2009) argued that writing activities do not receive sufficient attention in Turkey. Furthermore, Günel (2009) claimed that writing-to-learn activities, which were not in the area of interest of educational sciences research, was a new phenomenon waiting to be explored, and added that research on writing-to-learn could open up new horizons for Turkish researchers to support "the development of science literacy" and "meaningful learning of science", which is one of the goals in the Turkish education system.

It is asserted that while solving mathematical problems in traditional classes, students make use of writing to make record of their operations, and while doing so they are not aware of their own thoughts, they do not think about the solution of the problem, and they do not make a mental interpretation of their statements (Fluent, 2006). Hence, instead of the traditional approach, the use of conscious and purposeful writing activities that are conducive to analytical behavior by means of discussion activities in which the whole class can actively participate is recommended (Jurdak \& Zein, 1998). It is maintained that writing is more important and effective than spoken language as writing enables each word to form an image in a student's mind (Ergün \& Özsüer, 2006) and makes students' thoughts more concrete (Quinn \& Wilson, 1997). It is stated that as students are more active in learning environments where writing activities are utilized, they can make meaning out of what they learn and become aware of their own learning and development (Bolte, 1999). The realization of the benefits of writing activities and their impacts on education increasingly drew the attention of researchers and educationists toward this area of topic (Ntenza, 2006; Seto \& Meel, 2006). In numerous research studies on education of content knowledge, writing is not regarded solely as a language skill and a component of solely language education (Uğurel et al., 2009).

It is noted that mathematics is at the top of the list of subjects that are difficult to teach and learn (YetimKaraca \& Ada, 2018). According to Witzel and Riccomini (2007), the high number of students with a low level of academic achievement has created a pressing need for education researchers to conduct studies on new teaching strategies to increase academic achievement in mathematics. Thus, the writing activities in current 
mathematics curriculums could be considered an education strategy to identify learning needs and to decrease the gap between students' levels of achievement in education.

There are positive views in the literature on writing-to-learn, and it is recommended to be used in mathematics lessons as well (Burns, 2005; Jurdak \& Zein, 1998; Tekin-Aytaş \& Uğurel, 2016). However, researchers have expressed different views regarding the purpose of using writing activities. Some researchers have recommended using it as a means to organize students' perceptions and attitudes towards mathematics (Atasoy, 2005; Furner \& Duffy, 2002; Mason \& McFeetors, 2002; Nagin \& National Writing Project, 2003). Then there are studies in which writing is used as a method of alternative assessment to assess students' thoughts (Baxter, Woodward \& Olson, 2005; Burns, 2005; Miller, 1991; Nie, Yeo \& Lau, 2007). Some researchers have recommended using writing activities as a means to teach new concepts (Brandenburg, 2002; Burns \& Silbey, 2001; Cooley, 2002; Fuqua, 1997; Marlow, 2006; McIntosh \& Draper, 2001; Williams, 2003). They have stated that it could be used to develop students' metacognitive skills (Tanner, 2012; Kartalc1, 2018) or to gain insight into teachers' teaching processes (Atasoy, 2005; Seto \& Meel 2006). Moreover, various studies have been conducted on students' and teachers' views regarding the variety and practice of the writing activities implemented by teachers (Demircioğlu, Argün \& Bulut, 2010; Guce, 2018; Öztürk, Öztürk \& Işık, 2016; Phillis, 2020). However, Shield and Galbraith (1998) claimed that comprehensive studies were not conducted on writing activities. Similarly, Herrick (2005), who examined 55 studies on writing, stated that there were no studies investigating the development in the cognitive learning processes of students with different levels of academic achievement in curriculums where writing was intensively implemented. Hence, it is believed that the present study will fill in this gap in the literature.

It was observed in the related literature that experimental studies were mostly pre-ferred with the aim of revealing the effect of writing on students' academic achievement (Dur, 2010; Frenkel, 2004; Greer, 2010; Kasa, 2009; Pugalee, 2004; Y1lmaz, 2015). It was also observed that writing activities were mostly used while solving problems (Özkan, 2019). It has revealed that in these studies only general evaluations on the effect of writing activities were made and were thus insufficient in explaining contradictory findings. In addition, owing to the changes in the nature of mathematics learning environments, there is a need for further studies on the use of writing in mathematics (DiBartolo, 2000). Graham, Kiuhara and MacKay (2020) investigated the effect of writing-to-learn on mathematics by analyzing 21 experimental research studies in which there were various writing activities and sample groups with varying levels of performance. Their study revealed that writing-tolearn activities has a moderate degree of effect on learning mathematics. It was also recognized that limited information could be gained from the studies that they examined, so they recommended that comprehensive studies be conducted on writing-to-learn.

In recent years in Turkey, studies in which writing activities were utilized in mathematics education have been observed. In a study by Özkan (2019), how the mathematics algorithms written in a journal by a 6th grade student changed over time were analyzed. The data of this study, which employed a mixed-method research design, were collected merely in the topic of area measurement in a total of 13 lesson hours spread over five weeks. The study revealed that the writing activities had a positive effect on students' understanding of area measurement. It is recommended that the implementation of writing activities be planned to be used over a longterm period. Another study, which was conducted by Küçük (2019), aimed to examine the effect of writing activities associated with 13 learning outcomes in the learning domain of Probability and Statistics on 7th grade students' problem solving skills, and their attitudes to and anxieties in mathematics. The data of this study, which employed a quasi-experimental design, were collected over a period of seven weeks. The study revealed a statistically significant variance in favor of the experimental group in the scores obtained from scales used in accordance with the purpose of the study. A recommendation was made to conduct studies in which writing activities are used in different learning domains and in which a qualitative research design is used in order to gain more profound insight. One other study was conducted by Akkuş and Darendeli (2020), who examined a total of 35 research studies carried out in Turkey between the years 2005 and 2020 on writing in mathematics. Their study revealed that the number of studies in this area of topic was very low, that mostly experimental methods were employed, and that studies on topics other than numbers were insufficient. Furthermore, they stated that writing-to-learn in Turkey was mostly implemented in the area of science education and that the number of studies in the discipline of mathematics education should be increased.

The present study was designed to employ a qualitative research design lasting for 14 weeks, which is a relatively long period of time when compared to the studies in the related literature. Moreover, topic enrichment was ensured by preparing activities for six different units. The study can contribute to the development of a teaching method to be used by teachers intending to teach mathematics by employing a variety of writing activities and written communication; it can also guide them in activity development. It can provide them with information about how to utilize writing activities in their lessons and enable them to create new ideas. Hence, it is believed that the study will enable more mathematics teachers to use the writing-to-learn technique in their lessons. In addition, considering the results of the study, teachers can gain insight into how and to which groups 
writing activities can be implemented in their efforts to increase the mathematics achievement levels of students with varying academic achievements.

Importance is attached to studies on integrating various technologies (particularly computer technology) into studies in the area of mathematics education, yet these require huge costs and thus lead to the emergence of financial constraints (Bellamy, 2017). Moreover, teachers need to be provided with long-term in-service trainings in the use of these technologies (Braine \& McNaught, 2007). Conversely, writing activities require very low costs (cost of paper) and can be easily implemented under the guidance of the teacher (Bellamy, 2017).

The cognitive dimension of writing is comprised of ordering the acquired information, perceptions, and observations, and mentally processing and interpreting them (İpşiroğlu, 2006). Despite the existence of different definitions of cognitive development, the common feature of these definitions is that cognitive development is a mental activity (Losike-Sedimo, 2018). The development in the quality of students' explanations of mathematical topics, the increase in their use of terminologies, and the development in the accuracy of their calculations and their use of algorithms are all directly associated with students' cognitive developments (Baki, 2008).

The aim of the present study was (i) to compare the written responses of 7 th grade students, who were grouped as very low, low, average, high, and very high based on their academic achievements in mathematics lessons, where writing activities were used, and (ii) to analyze the contribution of these activities to students' cognitive learning in mathematics. To this end, the research question of the study was stated as follows: How does a mathematics learning environment supported with writing activities affect the cognitive development of 7 th grade students with varying levels of achievement?

\subsection{The Theoretical Framework of the Study}

A highly prevalent social-pedagogic movement, which was founded on Vygotsky's ideas, started in the former U.S.S.R. during the 1980s (Kerr, 1997). According to Vygotsky, knowledge is shared among individuals within a social environment, and it is the interaction within this social environment that knowledge is constructed. It was stated by Vygotsky that this is how the cognitive development of an individual could be ensured (Senemoğlu, 2000). It was also claimed that students' studying in the same environment with those who are at the same or a higher level helps them to reach a higher level of cognition (Gray \& Feldman, 2004). Moreover, according to Vygotsky, written language is not only more important and effective than spoken language, but is also different from spoken language in all respects in that it requires higher level of abstraction. In addition, writing is not directed to anyone, but is an internal dialogue. When an individual writes an explanation, s/he enters a process where s/he talks to him/herself (Vygotsky, 1985).

According to Vygotsky (1985), learners have two different levels of development. One of these is the actual development level, where the individual has the ability to learn certain topics on his/her own via his/her mental processing at that point in time. The other is the potential development level. This level is defined as the level to which learners can reach with the help of their teacher, parents or peers. The area between these two levels was defined by Vygotsky as the Zone of Promiximal Development (DeVries, 2000). The area between the actual development level and the potential development level can be illustrated as in Figure 1.

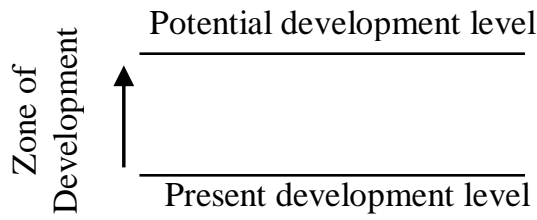

Figure 1. Zone of Proximal Development

Building upon Vygotksy's concept of ZPD, Albert (2000) proposed the concept of the Zone of Proximal Practice (ZPP). Students, who pass from the actual development level to the potential development level with the help of their peers or teachers, as stated in the ZPD, can use writing activities, which require more analytical thinking, transition to a condition where they can organize mathematical concepts and ideas by self-scaffolding with the aid of external help. In brief, writing functions as a bridge between ZPD and ZPP (Albert, 2000). By developing ZPD further, Albert (2000) schematized the transition to ZPP, as illustrated in Figure 2. 


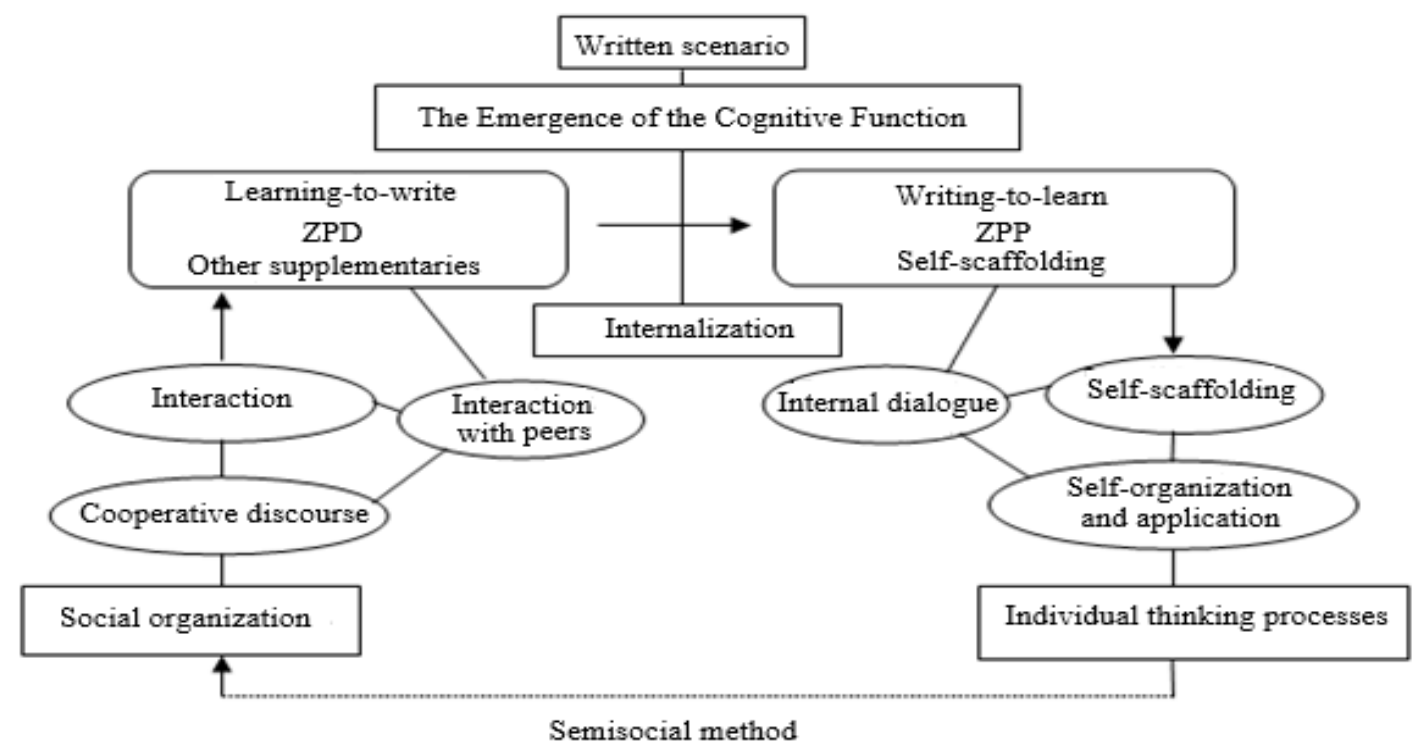

Figure 2. The relationship between ZPD and PLP (Albert, 2000)

It is stated that in ZPP, students independently organize and apply their ideas related to mathematical concepts. It is maintained that students who pass from ZPD to ZPP would develop in critical thinking skills and gain a more profound understanding of mathematics (Albert, 2000). The basic idea here is that social environment develops language, language develops writing, and writing develops thoughts.

\subsection{Writing Activities Utilized in Mathematics}

There is no known study that categorizes the writing-to-learn activities used in mathematics lessons. Many studies have focused on defining the writing activities that were used (Phillis, 2020; Markert, 2019). As a matter of fact, there are no clear boundaries between these definitions. Sipka (1992) developed a classification related to writing as a tool in mathematics education. According to Sipka, all writing activities can be grouped into two categories as formal and informal. Informal writing is content-focused. The reader is interested in the writer's opinions. In formal writing, the reader pays attention to the quality of the writing and the content.

Britton, Burgess, Martin, Mcleod and Rosen (1975) categorize writing activities into three groups: communication based formal writing (transactional writing), meaning-based writing (expressive writing) and poetic writing. The aim of transactional writing is to convince, inform, and teach. It is the most common type of writing used in school settings. Written and formal exams can be examples of this type of writing. Students use this type of writing when they write definitions or responses to questions. Moreover, chapters in books and research articles exemplify this type of writing. Expressive writing, on the other hand, is personal writing that is informal and unplanned, and reveals the writer's internal voice. Students naturally reflect their feelings and opinions about a particular topic. Journal and free writing are the most common samples of this type of writing. Writing a letter to a friend or family falls within this category. Another writing genre is poetic writing. This type of writing is the one that is least used in schools. The aim of this writing is to use writing like art. Algorithm, configuration and style are more important than content. Having students create poems with mathematical concepts, write a mathematical resume, or write an essay titled "a world without mathematics" are samples of poetic writing in mathematics classes (Lynch, 2003). Writing stories and songs are also within this category (Klishis, 2003). Fulwiler (1984) added a fourth style of writing to these three categories: mechanical writing. Fulwiler placed the writings teachers produce on the board while teaching into this category. Not much effort needs to be put into this type of writing. These categories do not have definite borders, though. To illustrate, King (1982) claimed that journal writing, placed in the sub-category of meaningful writing in Britton's categorization, would be within the category of transactional writing (communication based formal writing) if students wrote in their journals with the help of their teacher.

Burns (2004) classifies writing activities used in mathematics into four groups: journals, solving mathematical problems, explaining mathematical ideas, and writing about mathematical processes. Ishii (2003) stated that generally expository writing and journal writing were implemented as write-to-learn activities in mathematics classes. According to Ishii, journal writing refers to students' opinions written in response to a teacher's prompt or about an activity. As for expository writing, it is, by its nature, the act of explaining a question or problem. In the present study, the writing activities employed can be categorized as journal writing and expository writing. 
Beasley and Featherstone (1995) maintained that the choice of instructions, questions or scenarios used to have students do a writing activity were very important as they should be appropriate in quality and content to reveal students' opinions and assess their understanding of the topic. It has been stated that students should be able to reflect on these, choose and apply appropriate strategies, assess the rationality of their solutions, and trace their developmental process (Silver \& Smith, 1996; Klishis, 2003).

Colonnese, Amspaugh, LeMay, Evans and Field (2018) categorized writing that could be used for communication and reasoning at primary school level into four types: exploratory, expository, persuasive, and creative. They consider students' responses given to such question as "Why do we use fractions?" to explain their discovery of the concept of fraction as exploratory writing, while students' written responses to such an instruction as "Explain how you know that one third of a play area is bigger than one third of a pavement area" are considered expository writing. Persuasive writing requires students to produce writing by using basic constituents of persuasion, such as data, claim, and justification to answer such questions as "While comparing two elements, the whole of one of the elements is always bigger than half of another element. Do you agree or disagree and why?" Finally, in creative writing, similar to the questions in exploratory writing, students answer such questions as "If one third of it is in decimal terms is $0.333333 \ldots$, and two thirds $=0.666666 \ldots$, then why does three out of three equals 1 and not $0.999999 . . . ?$

Researchers in the literature have recommended that in writing activities in mathematics, attention should be paid to selecting prompts and questions that students can quickly and easily solve, that allow students the opportunity to reflect on their ideas, and questions that students can make sense of (Roskin, 2010). Moreover, they have stated that students should infer signs regarding topics that are not related to the topic being addressed within these prompts and questions (Klishis, 2003). Hence, in the present study the recommendations mentioned in the literature and stated above were take into consideration while preparing the writing activities.

\section{Method}

The qualitative research approach was employed in the present study. Qualitative studies allow researchers to conduct in-depth analyses of a study group's understanding of a topic, the definitions and explanations they make, and how these change (McMillan \& Schumacher, 2010).

\subsection{Study Group}

The study group in the study was comprised of a total of 37 (23 female, 14 male) students attending 7th grade in a primary school located in a town within the province of Trabzon. On the other hand, the study group of the pilot study was comprised of seventh grade 28 (15 female, 13 male) students attending a different primary school in the same town. The people living nearby the schools in the town center had a middle level of socioeconomic status. The students' level of academic achievement were generally average or low, yet there were also students with a good level of achievement.

\subsection{The Research Design}

During the research design stage, initially the units to be addressed in the first term as defined in the 7th grade mathematics curriculum were examined, and the materials to be used were prepared. The schematic explanation of the process prior to the main study are presented in Figure 3.

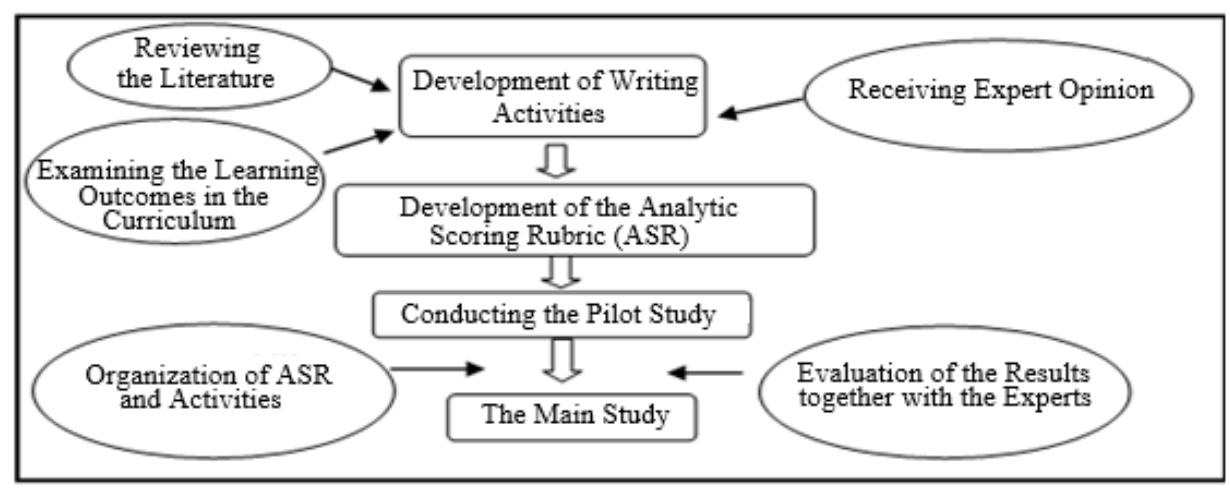

Figure 3. The schematic presentation of the processes prior to the main study

As can be observed in Figure 3, after the literature was reviewed and the learning outcomes in the curriculum were examined, expert opinions were received on the writing activities that were developed. Subsequently, an analytical scoring rubric (ASR) was designed to assess the writing activities. The next stage was the pilot study, which was conducted with a total of 28 seventh grade students for a period of 3 weeks in a primary school, which was different from the one where the main study was conducted. 
Three activities that were included in the pilot study were removed from the main study based on expert and teacher opinions and because they were found to waste much of the class time, to be at a higher level of difficulty than the students' level, and to be redundant as there were other activities related to the same topic they were addressing.

In addition, it was observed in the pilot study that reading out each student's score on the ASR was a waste of time; hence, in the main study, the scores were announced by posting them up on the bulletin board. Moreover, since it was observed in the pilot study that students were more concerned with their scores than in the feedback and in their errors, in the main study the activity papers were distributed to the students, and the feedback and the questions in the activity were discussed prior to hanging the scores on the bulletin board. Furthermore, some of the questions in the pilot study were revised based on expert opinion. To illustrate, in the second activity in the topic of lines and angles, the place of the angle was changed so that the question could address more learning outcomes. In the pilot study, students were required to produce journal writings. However, in these journal writings, it was observed that students explained what was done in class. Therefore, it was decided that students needed to be guided in the main study in order for them to write in accordance with the aim of the study. Accordingly, it was decided that the journal writings should have sub-titles (Appendix 1).

The main study was conducted with seventh grade primary school students for a period of 14 weeks. As part of the research study framework, teachers were initially informed about how to implement the writing activities in class. It is stated in the related literature that the easiest way of getting students accustomed to writing is having students write about their past experiences in mathematics (Burns, 1995). Accordingly, at the beginning of the activitie, the students were assigned homework to write about their past experiences in mathematics. More specifically, they were asked to write about all their feelings, opinions, good and bad memories, the mathematics topics they liked and disliked, and the connection between mathematics and other subjects as regards their past experiences in mathematics. However, this assignment was not assessed. Subsequently, how the activity was going to be implemented was explained in class and sample activities (Appendix 1) were distributed to the students and together reviewed.

The writing activities were generally implemented in the last 10 to 20 minutes of each two-hour lesson after the teacher completed her lesson in accordance with the curriculum. After the activity was completed, the students' writing papers were collected for the teacher to read and give feedback on. At the beginning of the following lesson, the papers were distributed to the students, who were asked to examine the feedback given. Subsequently, using different samples, the teacher made explanations to the students with the aim of correcting the most frequent errors they had made. Students' writing papers were assessed and marked in accordance with the ASR that was developed. A mathematics corner on the class bulletin boards were formed so that the students could see the ASR and some samples selected from the activities that were done. In this corner, the ASR was kept hanging on the board until the end of the term. Moreover, after each activity, the scores that the students received on the ASR were also hung on the board. Those who received a high score were announced in class. Based on these scores, the teacher sometimes delivered a talk to the class about the students' performances. At the end of the activitie, the students were categorized into five groups based on their academic achievement levels - very low, low, average, high, very high — and their responses to the writing task were examined.

\subsection{Data Collection Tools}

Writing activities and an analytic scoring rubric (ASR) were utilized as data collection tools in the present study. Detailed information about these two data collection tools is presented under two sub-titles below.

\subsubsection{Development of the Writing Activities}

In the present research, a total of 26 writing activities were implemented. Moreover, at the end of the unit, each student was asked to write in their journal, which amounted to 6 journal writings. These activities and journal writing tasks were designed in accordance with the related literature and the primary school mathematics education curriculum. Subsequently, three experts and one primary school mathematics teacher were asked to examine them.

In the present study, expository and journal writing tasks were used to implement writing activities within a three-stage plan. In all these stages, careful attention was given to ensure that the activities prepared addressed the learning outcomes in the mathematics curriculum, were associated with daily life, and enabled the students to engage in more detailed thinking. In the first stage, the writing activities that lay emphasis on the concept of the topic being addressed were implemented. In the second stage, the writing activities focused on the content of the topic. Finally, in the third stage, the journal writing were produced at the end of the unit. These stages are presented in Figure 4. 


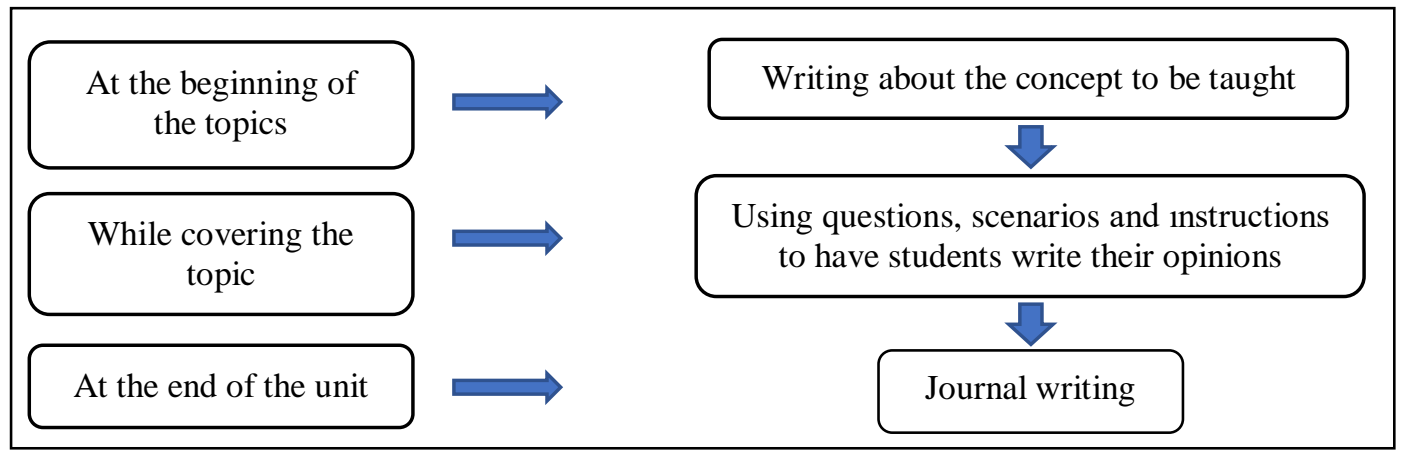

Figure 4. The three-stage plan of the writing activities

While writing their detailed explanations of their thought processes, they were told that they could ask for their teacher's or peers' assistance, and that they should write their thoughts including all the strategies and methods, and even write about thought processes by which they could not arrive at the correct solution or arrived at the wrong solution by writing such statements as "I thought of this, but could not arrive at the solution" or "arrived at the wrong solution." Moreover, they were told that they should make explanations as if they were explaining them to a 6th grade student, not worry about punctuation and grammar rules, not erase mistakes but just cross over the mistakes, that they could draw figures to explain their thoughts, form tables and give examples. Finally, they were told to read what they had written before they submitted their explanations. Writing as if they were explaining to students attending lower grades allows students to construct their own understanding of concepts and prevents them from repeating without understanding the knowledge they have (Hohenshell, Hand \& Staker, 2004; Hand, Yang \& Bruxvoort, 2007).

At the end of the units, the students were asked to write journal entries about what they learned in class, what they did in class, what they found difficult and confusing, and what they did to overcome these difficulties in a detailed way. Samples of writing activities that were implemented at the beginning of the topic, while the topic was being covered and at the end of the unit are presented and explained in detail below.

At the beginning of the topics:

The writing activity implemented at the beginning of the topics consisted of an assignment in which the students were asked to respond to a prompt by means of expository writing based on the mathematical concepts explained. The aim of this stage was to highlight mathematical concepts.

For example:

a.Imagine yourself as a rational number. Explain by writing about yourself and your relationship with your relatives (other rational numbers and number sets) under the title, "I am a rational number."

While covering the topic:

The activity that was carried out as the topic continued to be covered was an expository writing activity, which consisted of the responses the students gave to instructions, scenarios and open-ended questions related to the mathematical concept explained.

For example:

a.Based on the given data in the figure on the right hand side, Ahmet says lines $\mathrm{d}$ and e are parallel while Ayşe says they are not parallel. Who do you think is right? Explain your response by explaining your reasons.

b. $* 5$ is added to each side of the equation.

* Both sides of the equation is multiplied by 2 .

A student who did the operations in the same order as above to solve the equation found the solution set to be

12. Thus, how can this equation be found? Explain.

At the end of the unit:

At the end of the units (generally two or three times a week), the writing activity was writing in their journal. This activity was assigned as homework. The students were asked to bring this homework assignment to the next mathematics class. These journal prompts were developed based on the aim of the study and by benefitting from Lefler (2006). The journal writing activity was implemented by having students respond to the prompts consisting of the 4 sub-titles below.

a.Write a letter to a friend who is absent from class to summarize the topic we covered. The students were asked produce explanations in accordance with the given instructions: "Explain the topic to a friend who is absent (and is a low achiever in the lesson). Your friend does not know the topic and relies completely on what you will explain to him/her.

b. Order the concepts covered in the lessons and identify the relationship among them. 
c. State the difficulties or problems that you face in relation to the topic.

$\mathrm{d}$. What is the most important piece of information that you did not know before but learned after covering the topics?

Furthermore, the students were cautioned not to explain in their journals the common activities in class (the teacher had Ali come to the board) or incidents happening outside of class. During the activitie, the students were allowed to discuss among themselves and with their teacher, but they were definitely required to write without looking at each other's papers. Jurdak and Zein (1998) stated that in writing activities, the teacher should give short feedback in a short period of time, and that all the activities, except for the journals, should be scored. Accordingly, the teacher in the present study gave short feedback to student writings in order to motivate the students and to enable them to see their errors.

The number of the writing activities was determined by considering the learning domain, the sub-learning domain, the learning outcome, and the number of lesson hours. Sub-learning domains and the number of activities: Lines, angles, and angle measurement (2 activities); operations with whole numbers (10 activities); rational numbers (6 activities); algebraic expressions ( 2 activities); equations ( 3 activities); ratio and proportion ( 3 activities). A total of 26 writing activities were implemented. Based on the application time in the study, these were divided into three groups as at the beginning, middle and end of the study. Activities 1-9 were identified as those to be implemented at the beginning of the study, activities 10-18 in the middle, and activities 19-26 at the end. The study was implemented over a period of a total of 56 class hours. However, writing activitie was not done in the entirety of these class hours. The writing activities were generally implemented in the last 10-20 minutes of the 2-hour lessons. In addition to the writing activities, each student was asked to write at the end of the units, which amounted to a total of 6 journal writings.

\subsubsection{Development of the Analytic Scoring Rubric (ASR)}

DiBartolo (2000) stated that analytic scoring rubrics were effective and efficient tools in assessing writings. Unlike holistic and characteristic scoring rubrics, analytic scoring rubrics (ASR) necessitate the deconstruction of the performance into its constituents or the product into separate sections and the assessment of each skill independently, and then adding the scores obtained from each section to find the total or the average score. Thus, analytic scoring rubrics are developed to assign different scores to different dimensions of a study or product.

Even though scoring rubrics that are ready-made, adapted or prepared by the researcher can be utilized to assess writing activities, in the present study an adapted scoring rubric was used in order to increase the reliability of the study. A preliminary analysis of the written data obtained from the study was done by using the draft of the scoring rubric that was adapted from Lim and Pugalee (2006a; 2006b), and it was decided that the rubric was appropriate for the study.

The ASR was submitted to three domain experts and one primary school mathematics teacher for expert opinion, and it was decided that it was appropriate to the nature of the study. Thus, the scoring rubric, the dimensions of which are presented below, was used in the main study.

ASR consists of three categories. These are as follows: (1) Features of the explanations, (2) Use of mathematical language, and (3) Mathematical algorithms and calculations. The students' writings were marked under these headings by using the ASR.

\subsection{Data Analysis}

Prior to the analysis of the data in this section, how the students were categorized according to achievement levels is explained. Subsequently, an explanation is provided about how the writing activities were divided into three groups depending on their time of implementation: at the beginning, middle and the end of the study. Then follows an explanation on how the written responses given by the students who were grouped according to their academic achievement levels were analyzed.

Since the fundamental problem of the research was identifying the cognitive and affective developments of students with varying levels of academic achievement in writing activities and revealing the relationship between the students' responses given in the writing activity, it was essential to group the students in accordance with their academic achievement levels. To this end, the steps that were followed are explained below:

a) Initially, the means of the students' grade 6 term 1 and term 2 written exam scores (a total of 6 exams) were calculated. The students' performance evaluation scores were not taken into consideration in this calculation.

b) Because the mean scores of some of the 24 students with average academic achievement scores were very close to each other, the students at this level of achievement were divided among themselves into three groups as low, average, and high level of academic achievement based on the opinions of the teacher 
(who had been the teacher of the students for the past one year and thus had a clear idea of the students' levels).

Table 1. The number of students in each group of academic achievement level 1

\begin{tabular}{cccccc}
\hline & Mean score 0-25 & & Mean score 30-68 & Mean score 75-100 \\
\hline \multirow{2}{*}{$\begin{array}{c}\text { Level } \\
\text { Number of } \\
\text { students }\end{array}$} & 10 & $\begin{array}{c}\text { Low } \\
\text { (Level E) }\end{array}$ & $\begin{array}{c}\text { Average } \\
\text { (Level C) }\end{array}$ & $\begin{array}{c}\text { High } \\
\text { (Level B) }\end{array}$ & $\begin{array}{c}\text { Very High } \\
\text { (Level A) }\end{array}$ \\
\hline
\end{tabular}

As can be observed in Table 1, based on their grade 6 exam. scores, 10 students with a mean score between 0-25 was labelled as "very low" (level E) and 24 students with a mean score between 30-68 were divided among themselves into varying achievement levels based on the teacher's opinion: 9 students were labelled as "low" (level D), 10 students as "average" (level C), and 5 students as "high" (level B). In addition, 3 students with a mean score between 75-100 was labelled as "very high" (level A). In this way, the academic achievement level groups were formed.

The responses given to the writing activities by the students, who were divided into academic achievement levels, were analyzed via the content analysis method. Prior to analyzing the students' responses, to establish a general framework, ASR was used to identify three themes. The data were coded and associated with these themes. First, all the responses given to the writing activities by the students, who were divided into groups based on achievement levels, were examined superficially one by one within each group. While doing so, notes were taken. After this preliminary analysis, all the responses were re-examined from the start for a more detailed analysis. The similarities and differences between the codes that had emerged were identified, and those that were related were grouped together and associated with the themes. The final versions of the themes and codes are presented in Table 2.

Table 2. Themes and codes

\begin{tabular}{|c|c|}
\hline Themes & Codes \\
\hline $\begin{array}{l}\text { 1. Features of the } \\
\text { Explanations }\end{array}$ & $\begin{array}{l}\text { a. Writing detailed, explicit and clear responses } \\
\text { b. Supporting explanations with examples } \\
\text { c. Writing irrelevant explanations } \\
\text { d. Writing explanations based on their visual perceptions } \\
\text { e. The inconsistencies among different explanations on the same topic and } \\
\text { between explanations and mathematical operations }\end{array}$ \\
\hline $\begin{array}{l}\text { 2. Using the } \\
\text { Mathematical } \\
\text { Language }\end{array}$ & $\begin{array}{l}\text { a. Using mathematical symbols } \\
\text { b. Using mathematical words } \\
\text { c. Using mathematical figures } \\
\text { d. Using unique words and symbols }\end{array}$ \\
\hline $\begin{array}{l}\text { Mathematical } \\
\text { Algorithm and } \\
\text { Calculations }\end{array}$ & $\begin{array}{l}\text { a. Making calculations that are incomplete, irrelevant, or based on visual } \\
\text { perceptions } \\
\text { b. Being able to develop different structural and calculation methods } \\
\text { c. Evaluating the solution (checking the accuracy and rationality of the solution) }\end{array}$ \\
\hline
\end{tabular}

As can be observed in Table 2, the findings of the research study were grouped under three themes: features of the explanations use of mathematical language, mathematical algorithm and calculations. Under these themes are the related codes. In the final stage, the researcher made explanations to add meaning to the data, to explain the relationships among the findings, to establish a cause-effect relationship, to draw some conclusions from the findings, and to explain the significance of the obtained results (Yıldırım \& Şimşek, 2005).

The scores that the students, who were grouped based on their academic achievement levels, obtained on the analytic scoring rubric were classified in accordance with the three themes on the rubric (mathematical explanations, use of mathematical language, mathematical algorithm and calculations). First scoring the students' responses in the writing activities and then classifying them based on achievement levels is a factor that increases the reliability of the research study. Subsequent to the classification, whether or not there was developmental progress within each group of academic achievement level under each theme was examined. To this end, the means of the scores that the students obtained on the ASR for the writing activities, which were categorized into three groups as activities for the beginning, middle and end of the study, were calculated and interpreted.

The scoring on. The ASR was done by the researcher and the teacher independent of each other. The analysis that was run to examine the consistency between the scores yielded a Pearson correlation coefficient of .92. This 
coefficient was found to be sufficient as it indicates a high degree of inter-rater compatibility (Büyüköztürk, 2005). The students who participated in the study were coded as S1, S2, .., S37. All the activities, except for the journal writing activitie, were marked by utilizing the analytic scoring rubric.

\section{Findings}

After the written responses in the writing-to-learn activities in the present study were examined, three different themes related to students' cognitive development were formed and coded. Various information regarding these themes and codes with respect to students' cognitive developments have been presented through tables. In Tables 2 and 3, expressions such as A3, B5, and C10 in the column titled 'Level' indicate the number of students. To illustrate, A3 indicates that there were 3 students at level A. Table 4 displays sample student responses. In addition, at the end of each theme, the mean scores students earned from the related part of ASR are presented in accordance with their achievement level.

\subsection{Findings Regarding the Theme of "Features of the Explanations"}

The written responses given in the activities by the students, whose achievement levels were categorized, were examined under the theme "features of the explanations", and the codes that were formed are presented in Table 3. This table also presents from which student papers the codes were arrived at and at which stage of the study they were observed in the activities that were implemented.

Table 3. The students within the codes formed under the theme of 'features of the explanations'

\begin{tabular}{|c|c|c|c|c|c|c|}
\hline & de & $\begin{array}{c}\text { Writing } \\
\text { detailed, clear, } \\
\text { and } \\
\text { comprehensible } \\
\text { responses }\end{array}$ & $\begin{array}{c}\text { Supporting } \\
\text { explanations } \\
\text { with } \\
\text { examples }\end{array}$ & $\begin{array}{c}\text { Writing } \\
\text { irrelevant } \\
\text { explanations }\end{array}$ & $\begin{array}{c}\text { Writing } \\
\text { explanations } \\
\text { based on their } \\
\text { visual } \\
\text { perceptions }\end{array}$ & $\begin{array}{l}\text { The inconsistencies among } \\
\text { different explanations on } \\
\text { the same topic and between } \\
\text { explanations and } \\
\text { mathematical operations }\end{array}$ \\
\hline \multirow{5}{*}{ 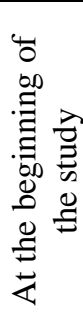 } & $\mathrm{A}_{3}$ & $\mathrm{~S} 1, \mathrm{~S} 2, \mathrm{~S} 3$ & $\mathrm{~S} 1, \mathrm{~S} 2, \mathrm{~S} 3$ & ------- & ------- & ------- \\
\hline & $\mathrm{B}_{5}$ & S4 & S5, S6 & ------- & S7 & ------- \\
\hline & $\mathrm{C}_{10}$ & . & S8, S9,S10 & $\begin{array}{l}\text { S8, S11, } \\
\quad \text { S12 }\end{array}$ & $\begin{array}{c}\text { S10, } \\
\text { S13, S14, }\end{array}$ & S8, S13 \\
\hline & $\mathrm{D}_{9}$ & ------- & S15, S16, & S18,S19 & $\mathrm{S} 21$ & $\mathrm{~S} 22, \mathrm{~S} 17, \mathrm{~S} 23$ \\
\hline & $\mathrm{E}_{10}$ & -------- & S17 & $\begin{array}{l}\mathrm{S} 20, \mathrm{~S} 16, \\
\mathrm{~S} 24, \mathrm{~S} 25, \\
\mathrm{~S} 26, \mathrm{~S} 27\end{array}$ & $\begin{array}{l}\text { S26, S27, S28, } \\
\text { S23, S29 }\end{array}$ & S27, S28, S30, S29 \\
\hline \multirow{5}{*}{ 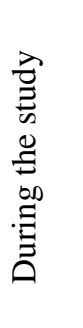 } & $\mathrm{A}_{3}$ & $\mathrm{~S} 1, \mathrm{~S} 2, \mathrm{~S} 3$ & $\mathrm{~S} 1, \mathrm{~S} 2, \mathrm{~S} 3$ & ------ & ------- & ------- \\
\hline & $\mathrm{B}_{5}$ & $\begin{array}{l}\text { S33 S7, S5 } \\
\text { S4, S6 }\end{array}$ & S6, S33, S4 & ------- & ------- & ------- \\
\hline & $\mathrm{C}_{10}$ & $\begin{array}{c}\text { S14, S8, S31, } \\
\text { S10 }\end{array}$ & $\begin{array}{l}\text { S31, S8 S11, } \\
\text { S14, S12 }\end{array}$ & ------ & ------- & S8 \\
\hline & $\mathrm{D}_{9}$ & S18, S17 & S16 & ------- & $\mathrm{S} 21, \mathrm{~S} 16$ & ------- \\
\hline & $\mathrm{E}_{10}$ & ------- & ------- & $\begin{array}{l}\text { S27, S25, } \\
\quad \text { S23 }\end{array}$ & $\begin{array}{l}\text { S26, S25, } \\
\text { S30,S27 }\end{array}$ & S26, S23,S28, S25 \\
\hline \multirow{5}{*}{ 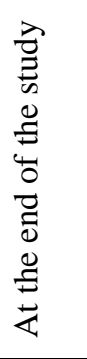 } & $\mathrm{A}_{3}$ & $\mathrm{~S} 1, \mathrm{~S} 2, \mathrm{~S} 3$ & $\mathrm{~S} 1, \mathrm{~S} 3, \mathrm{~S} 2$ & ------ & ------- & ------- \\
\hline & $\mathrm{B}_{5}$ & $\begin{array}{l}\text { S33,S4,S6, } \\
\text { S5 }\end{array}$ & $\begin{array}{l}\text { S7, S6, S4, } \\
\text { S33 }\end{array}$ & --- & -- & \\
\hline & $\mathrm{C}_{10}$ & $\begin{array}{l}\text { S11,S31, } \\
\text { S14,S8, S10 }\end{array}$ & $\begin{array}{l}\mathrm{S} 14, \mathrm{~S} 8, \mathrm{~S} 31 \\
\mathrm{~S} 10, \mathrm{~S} 31\end{array}$ & ------- & -------- & ------- \\
\hline & $\mathrm{D}_{9}$ & $\begin{array}{l}\text { S22, S18, } \\
\text { S16,S15 }\end{array}$ & $\mathrm{S} 15, \mathrm{~S} 16$ & ------- & ------- & S16 \\
\hline & $\mathrm{E}_{10}$ & ------- & ------- & -------- & $\begin{array}{l}\text { S29,S25 S32, } \\
\text { S24, S27 }\end{array}$ & $\begin{array}{c}\mathrm{S} 29, \mathrm{~S} 25, \mathrm{~S} 27, \mathrm{~S} 23 \\
\mathrm{~S} 32, \mathrm{~S} 37\end{array}$ \\
\hline
\end{tabular}

As can be observed in Table 3, in terms of the code of 'writing detailed, clear, and comprehensible responses', it can be deduced that the clarity of the responses of the level B and level C students improved significantly and that some of the level D students showed progress. As regards the 'writing irrelevant explanations' code, it was revealed that level E students had produced irrelevant explanations at the beginning and during the study, while level $\mathrm{C}$ and level $\mathrm{D}$ students had produced irrelevant explanations in some activities at the beginning of the study, but in the middle and at the end the study, they had no irrelevant explanations. The remaining level $\mathrm{A}$ and level $\mathrm{B}$ students were found to have written no irrelevant explanations to any of the activities in the study. In terms of the code titled 'Writing explanations based on their visual perceptions', no responses were identified to exemplify this condition among the level E students overall. Some of the level D students were found to have given responses to the activities at the beginning and during the study based on their 
visual perceptions, while only several of the level B and level C students had given such responses to some of the activities at the beginning of the study. This condition was not observed in the responses of level A students.

In the code of 'inconsistencies among different explanations on the same topic and between explanations and mathematical operations', this condition was observed in the responses of level E students throughout the study. While this condition was observed in the responses of three level D students, toward the end of the study, this number dropped to one student. Even though similar conditions were observed in two level C students at the beginning of the study, in the continuation of the study, no such condition was encountered. As for the students in the other academic achievement levels, no finding to exemplify this kind of a condition was observed in any stage of the study.

In terms of the code of 'supporting explanations with examples', it was revealed that level E students had not written any examples in their explanations. On the other hand, the students in the other groups of academic achievement levels, particularly those at levels A, B, and C, were found to have provided examples while writing explanations.

Sample quotations from the students' written responses to the activities in relation to the theme of 'features of the explanations' are presented in Table 4.

As can presented in Table 4, level A students generally wrote very detailed and much clearer statements than the students at the other levels at the beginning, during and at the end of the study. S2 made a detail explanation of the conditions of the lines in relation to each other in activity 2 at the beginning of the study. In activity 11 , implemented during the middle of the study, the same student calculated the difference between the actual temperature and the temperature wanted as $360 \mathrm{C}$ and then calculated the change in temperature in 1 hour. Afterward, by finding the change in temperature in 5 hours and then subtracting it from the initial temperature, the student arrived at the result. In activity 19, implemented toward the end of the study, the same student explained in detail that the algebraic statements in the parentheses would not be equal due to the place of the parentheses. Furthermore, the students at this level provided examples while writing answers in the activities. In activity $6, \mathrm{~S} 3$ stated that when negative numbers are multiplied by 10 , they become smaller and wrote examples.

As can be observed in Table 4, S7, a level B student, has not written a detailed response while answering the question in activity 4 . This student made an explanation only by using a mathematical symbol. However, the same student gave a more detailed answer in activity 17 somewhere in the middle of the study. Toward the end of the study, in activity 23, S7 showed one side of the eraser with the x symbol. Then for the short side of the book, to show that the eraser is added tip to tip three times but falls short $6 \mathrm{~cm}$, s/he preferred the algebraic representation of " $x+x+x+6$ ", instead of $3 x+6$. Similarly, $s$ /he showed the long side of the book in a detailed in the following way: " $x+x+x+x+x-2$ ". However, this student expressed both conditions by using the multiplication operation as well. Even if the students at this level made explanations based on their visual perceptions in the activities implemented at the beginning of the study, they associated these explanations with mathematical knowledge. In activity 2, S7 made the following explanation: "as can be seen in the figure, lines d and e have been drawn parallel to each other" and continued to write "the angle of line e is equal to the angle of line d". In addition, s/he calculated the values of the angles on the figure. S7 wrote a story in activity 22 to exemplify his/her explanations. S7 explained the solution of the equation in the following way: "There is virus $\mathrm{x}$ in the $1 \mathrm{st}$ town. There is no virus in the 2 nd town. To cross over to the 2 nd town, the ones in the 1 st town need to change [their] signs. The military police stops the ones wanting to cross over to the 1 st town and asks them to change [their] signs..." Similarly, in the same writing activity, S33 wrote an explanation as follows: "for instance, let me explain to you how to find the solution of $y+4=14$; $y$ is sick and has a contagious disease. For his reason, it needs to cross the bridge to go to the other 4 villages. But it gets caught by the military police and changes its sign in case it has any illness and +4 goes to the village as -4 . As a result, $y=10$." The students exemplified their explanations. 
Table 4. Samples from student responses under the theme of 'features of the explanations'

¿ Act.

Sample Responses

2 The cupboard in the figure are parallel lines because the wooden boards within the cupboard are A arranged one underneath each other and remain opposite each other. So this is a parallel line and, in addition, when we extend the wooden board inside, they never intersect each other. And this is a feature of parallel lines. (S2)

6 Yes there is because when negative numbers are multiplied by 10, they get smaller because when a normal multiplication operation is done, the result is big, but if both multipliers have opposite signs, then the result will be negative, that is it will be smaller. The operations below exemplify this. $(-30) \cdot(+10)=(-$ 30) $(-30)<(-3) \quad(-5) \cdot(+10)=(-50) \quad(-50)<(-5) \quad(S 3)$

$4 \quad e)$ this statement is correct. But sometimes it can be wrong. E.g the correct ones: $(+) .(+) .(+)=(+)$ those B that are never correct: $(+) .(-) .(+)=(+) f)$ this statement is never correct. E.g.

an incorrect one: $(+) .(+) .(+)=(-)$ a correct one: $(+) .(+) .(+)=(-) g)$ this statement is correct. A correct one $(+) \cdot(-)=(+)(S 7)$

2 I think what Ahmet says is correct because as it is seen in the figure, $d$ and e are lines that are drawn parallel to each other, and these lines are parallel to each other. I think Ahmet is on the perfectly correct line of thought. My view is that the angle of this line e is equal to the angle of line d (S7)

... another of its angle is 1280 which is its opposite angle of 1280 on angle d. And the opposite angle of

C 2 angle 1280 on line e ... it is angle 520 on line d which is the alternate exterior angle of the angle on line $e$. (S8)

1 The ladder that is presented in the diagrams is given as a rectangle and its opposite two sides are equal. All of its angles are 900. The one in diagram B is given as a triangle and a trapezoid. And the one in diagram $C$ is given with one rungs being parallelogram. (S8)

D 2 This parallel line is $180^{\circ}$. It turns out to be $52^{\circ}$ and $128^{\circ}$. And a perpendicular line is $90^{\circ}$. (S21)

E 2 ...because their angles are the same, I found the answer to be parallelogram. (S24)

11 If the laboratory's temperature dropped from $14 c^{0}$ to $-22 c^{0}$ then we need to first find how much it drops in 9 hours. We will find it by doing $(+14)-(-22) .(+14)+(+22)=36 c^{0}$ dropped in 9 hours. We need to find how much it dropped in 1 hour so that we can find 5 hours. Then; $(+36):(+9)=+4$ dropped in one hour. We are going to find how much it is at the end of 5 hours. $(+4) .(+5)=20$. Now let's find its temperature. If the room temperature is $14 c^{0}$ we find the answer as $(+14)-(+20)=(+14)+(-20)=-6(S 2)$

17 First if we start by explaining these operations; first Ali equalized the numerators without converting this operation to an improper fraction and then did the operation. As for Ayşe ...later equalized the numerators and did the subtraction operation. And Ahmet first equalized the denominators... now according to this, it is Ayșe who did the correct operation because Ayșe, as I mentioned above, first converted the operation into an improper fraction ... if we were to show the operation as an example; ( $I$ mean in my opinion)...(S7)

C 14 The figure $2 / 3$ is half of figure 4/6. In this way, figure 4/6 is two times 2/3. For equality in a rational number, the numerator and the denominator should be multiplied by the same number. (S8)

D $185+12=17$ Trabzonspor, $1+6=7$ Beşiktaş...5 people do not support a team (S16)

I don't think they are equal. $\left(2 x^{3}\right)$ is in parentheses. In this case, a change can occur. If we open this up; it

A 19 means multiplying 2 three times. I mean it is $2 x .2 x .2 x$. The result of these operations is $(2 x)^{3}=8 x^{3}$. In this case, it would be $8 x^{3} \neq 2 x^{3}$ (S2)

When measuring the short side of the book with an eraser, when it is placed tip to tip 3 times it would be

$233 x$. I mean, it would be $=x+x+x+6$. $6 \mathrm{~cm}$ would be left. If it is added 5 times, I mean it would be $=x+x+x+x+x-2$. And $2 \mathrm{~cm}$ would be extra $\ldots x+x+x+6=3 x+6 \quad x+x+x+x+x-2=5 x-2$ and from this, the equation $3 x+6=5 x-2$ emerges. ( $S 7$ )

B

$22 x+9=30$ now I'm going to explain the computation I gave above. Now in one city, there are two towns. In the 1st town, there is virus $x$; in the other town, there is no virus. The numbers in the 1st town want to go to the other town ... while crossing over, it gets caught by the military police. The military police asks where it is going. +9 answers. Then, the military police says to +9 that if it wants to cross over, it needs to change its sign. +9 accepts, and crosses over as -9 . Now, if we do the operation; $x+9=30 \quad x=30-9$ $S=\{21\}$. And -9 will have freed itself from the virus. (S7)

24 If one of the two quantities is increasing and the other is also increasing at the same rate or if one is decreasing while the other is also at the same rate... this is called direct proportion. If we give an example

C from daily life: a driver ...because one increases and ...this is called direct proportion. Reciprocal proportion... when one of the quantities increases and the other does at the same rate ... if one is decreasing, while the other is increasing at the same rate, this is called reciprocal proportion. If 10 workers construct a building in 40 days, how many days will it take 7 workers to build it? (S8)

D $19(2 x)^{3}$ and $2 x^{3}$ algebraic expressions are equal to each other because the results are the same. When its square is multiplied, it gives a correct result. $2.6=6 \quad 3.2=6 \quad 6.6=36(S 21)$

20 If $x$ unit square increases by 3 , the side of the square increases by 3 units ... the result is $18.3 \times 3 \times 3 \times 3=18$ (S24)

19 It is not equal because one of them is within parentheses and one of them is out of the parentheses. That's why they are not equal to each other. (S27) 
As presented in Table 4, the explanations that S8, a level C student, wrote for activity 2 at the beginning of the study were not comprehensible nor clear. S8 wrote more explicit, clear and comprehensible statements in the activities further on in the study. S8 was able to explain ratio and proportion by giving examples in activity 24 implemented toward the end of the study. It was observed that level $\mathrm{C}$ students generally made explanations at the beginning, during and end of the study. However, even though these explanations were not explicit and clear at the beginning of the study, towards the end of the study they were more explicitly, comprehensible, and clear. Even though some students at this level produced irrelevant explanations in the activities at the beginning of the study, they stopped doing so in the activities implemented towards the end of the study. In the explanations S8 wrote for activity 1 at the beginning of the study, s/he noted the triangle, trapezoid and parallelogram, which are irrelevant to the topic of the position of the lines with respect to each other. Even though this student produced irrelevant explanations to the questions in activities 2 and 6, she stopped writing unnecessary and irrelevant explanations in writing activities at later stages in the study. Some of the students at this level wrote explanations based on their visual perceptions. Even though some of the students' explanations were wrong, they made effort to establish an association with mathematical knowledge. In activity 2, based on his/her visual perception, S14 wrote, "What Ayşe says is correct because lines d and e will not overlap no matter how much they are extended." When the teacher asked S14 why the lines did not overlap, s/he answered by saying, "teacher, they seem to be parallel." Some of the students were observed to have internalized what they wrote at the beginning of the study and did not produce conflicting explanations towards the end of the study. To illustrate, in activity 14 , even though $\mathrm{S} 8$ wrote that $4 / 6$ was two times $2 / 3$, at a later stage s/he noted that the numerator and denominator needs to be multiplied by the same number for rational numbers to be equal. These two explanations are the opposite of each other and shows that the student had not internalized what s/he had written. Similar errors were identified in later activities in the responses of the same student.

As can be observed in Table 4, it was revealed that although level D students produced irrelevant explanations in some of the activities, they stopped producing irrelevant explanations in the activities towards the middle and end of the study. In activity 2, S21 wrote an irrelevant response, in fact, 'perpendicular line' instead of 'right angle' and 'parallel line' instead of 'straight angle', as shown below. However, the student did not produce such explanations in activities implemented towards the end of the study. In activity 18, implemented somewhere around the middle of the study, S6 added all the numbers s/he saw while writing his/her response. Toward the end of the study, even if the students wrote inaccurate statements like S21, they tried to associate what they wrote with mathematical knowledge.

As presented in Table 4, the students at level E were found to have produced explanations that were not sufficiently explicit, comprehensible, and clear. S24 provided a wrong answer to the question in activity 2 , one of the first activities of the writing activities used as a data collection tool. The response written by S24 shows that it does include sufficiently explicit, comprehensible, and clear statements for the readers to understand. S/he wrote irrelevant explanations because in the topic of angles in lines, parallelograms were not mentioned at all. The response produced for activity 20 by S24 was not only worded wrongly but also lacked detail and sufficient explanation. To answer the questions, the students at this level produced explanations based on their visual perceptions. To illustrate, in the response S27 gave to activity 19 toward the end of the study, s/he produced an explanation in which no mathematical calculation was done but was based on visual perceptions based on the position of the parentheses.

\subsubsection{The Means of the Scores the Students Received from the Theme of 'Features of the Explanations' on the $A S R$}

The means of the scores the students received from the 'Features of the explanations' theme are presented in Figure 20. Prior to the assessments, the activities were grouped into 3 depending on at which stage of the study they were to be implemented: activities 1-8 ( 1 and 8 included) at the beginning of the study, activities 10-17 (10 and 17 included) during the study, and activities 19-26 (19 and 26 included) at the end of the study. Activity 9, which fell between the activities at the beginning and those during the study, and activity 18, which fell between the activities during the study and those at the end of the study, were not included.

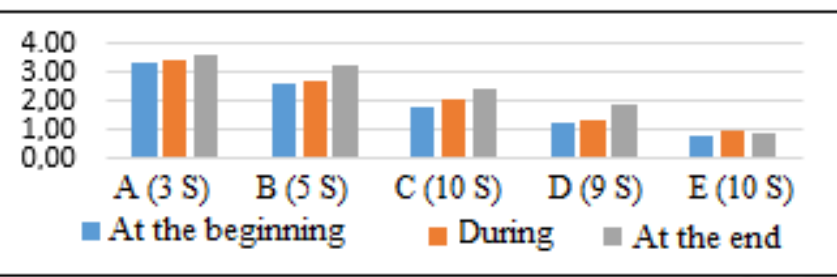

Figure 5. The means of the scores the students obtained from the theme of 'features of the explanations' on the ASR 
As can be observed in Figure 5, there are no significant differences between the scores that students at levels $\mathrm{A}$ and $\mathrm{E}$ received at the beginning, during, and at the end of the study. It was revealed that there was an increase in the means of the scores received by the students at levels B, C, and D at the end of the study. It can claimed that the most unsuccessful students in the theme of 'clarity of mathematical explanations' in activities across all stages of the study were those in group E. Moreover, a difference was observed between the mean scores of the students, who were grouped according to their levels of achievement, in the activities across all stages of the study (beginning, during, and end).

\subsection{Findings Regarding the Theme of "Using Mathematical Language"}

The codes that emerged under the theme 'using mathematical language' after analyzing the written responses given in the activities by the students, who were grouped according to their academic achievement levels, are presented in Table 4. The table presents information regarding from which students' responses the codes emerged and at which stage of the study the codes were observed in the activities.

Table 5. The students within the codes formed under the theme of the use of mathematical language

\begin{tabular}{|c|c|c|c|c|c|c|}
\hline & 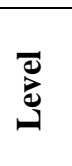 & $\begin{array}{c}\text { Using } \\
\text { mathematical } \\
\text { symbols }\end{array}$ & $\begin{array}{c}\text { Using } \\
\text { mathematical } \\
\text { words }\end{array}$ & $\begin{array}{c}\text { Using } \\
\text { mathematical } \\
\text { figures }\end{array}$ & $\begin{array}{c}\text { Using unique } \\
\text { mathematical } \\
\text { words and } \\
\text { symbols }\end{array}$ & $\begin{array}{l}\text { Being aware of } \\
\text { the different } \\
\text { symbols used }\end{array}$ \\
\hline \multirow{5}{*}{ 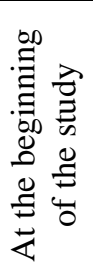 } & $\mathrm{A}_{3}$ & $\mathrm{~S} 1, \mathrm{~S} 2, \mathrm{~S} 3$ & $\mathrm{~S} 2, \mathrm{~S} 1, \mathrm{~S} 3$ & $\mathrm{~S} 2, \mathrm{~S} 1, \mathrm{~S} 3$ & ------- & \\
\hline & $\mathrm{B}_{5}$ & S5, S7, S33 & S6,S4 & S33, S5 & S33 & \\
\hline & $\mathrm{C}_{10}$ & $\begin{array}{c}\text { S9, S10, S11, } \\
\text { S8, S14 }\end{array}$ & S12, S9 & $\mathrm{S} 14, \mathrm{~S} 12, \mathrm{~S} 9$ & $\begin{array}{l}\text { S31, S9, S14, } \\
\text { S12, S34 }\end{array}$ & -- \\
\hline & $\mathrm{D}_{9}$ & $\mathrm{~S} 15, \mathrm{~S} 35$ & $\mathrm{~S} 21, \mathrm{~S} 35, \mathrm{~S} 20$ & S18 & $\mathrm{S} 18, \mathrm{~S} 22$ & \\
\hline & $\mathrm{E}_{10}$ & S32, S27 & $\mathrm{S} 27, \mathrm{~S} 25$ & $\mathrm{~S} 25, \mathrm{~S} 23$ & S32 & \\
\hline \multirow{5}{*}{ 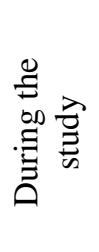 } & $\mathrm{A}_{3}$ & $\mathrm{~S} 1, \mathrm{~S} 3, \mathrm{~S} 2$ & $\mathrm{~S} 2, \mathrm{~S} 1, \mathrm{~S} 3$ & $\mathrm{~S} 1, \mathrm{~S} 3, \mathrm{~S} 2$ & S3 & $\mathrm{S} 3, \mathrm{~S} 2, \mathrm{~S} 1$ \\
\hline & $\mathrm{B}_{5}$ & $\mathrm{~S} 33, \mathrm{~S} 4, \mathrm{~S} 7$ & S7,S6, S26,S4 & S33, S6 & $\mathrm{S} 5, \mathrm{~S} 4$ & S6,S4 S5, S33 \\
\hline & $\mathrm{C}_{10}$ & S9, S34, S10 & $\begin{array}{l}\text { S11, S9, S14, } \\
\text { S10, S34 }\end{array}$ & S9, S12, S14 & S10, S9, S13 & $\begin{array}{l}\text { S14, S10, S9, } \\
\text { S31, S11, S8 }\end{array}$ \\
\hline & $\mathrm{D}_{9}$ & $\mathrm{~S} 19, \mathrm{~S} 16$ & S20, S18, S35, S17 & $\mathrm{S} 19, \mathrm{~S} 18$ & $\mathrm{~S} 20, \mathrm{~S} 35, \mathrm{~S} 19$ & ------ \\
\hline & $\mathrm{E}_{10}$ & S30, S26 & $\mathrm{S} 24, \mathrm{~S} 27, \mathrm{~S} 25$ & $\mathrm{~S} 25, \mathrm{~S} 23, \mathrm{~S} 24$ & $\mathrm{~S} 30$ & ------- \\
\hline \multirow{5}{*}{ 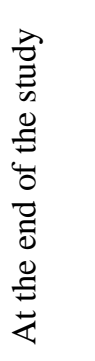 } & $\mathrm{A}_{3}$ & $\mathrm{~S} 2, \mathrm{~S} 3, \mathrm{~S} 1$ & $\mathrm{~S} 2, \mathrm{~S} 3, \mathrm{~S} 1$ & $\mathrm{~S} 2, \mathrm{~S} 1, \mathrm{~S} 3$ & S1 & $\mathrm{S} 2, \mathrm{~S} 3, \mathrm{~S} 1$ \\
\hline & $\mathrm{B}_{5}$ & $\begin{array}{c}\text { S5, S33, S7, S4 } \\
\text { S6 }\end{array}$ & $\begin{array}{c}\text { S5, S33, S7, S4, } \\
\text { S6 }\end{array}$ & $\begin{array}{c}\text { S33, S4, S6, S7, } \\
\text { S5 }\end{array}$ & --- & S4, S7, S33, S6 \\
\hline & $\mathrm{C}_{10}$ & $\begin{array}{l}\text { S9, S34, S31, S12, } \\
\text { S10, S13,S14 }\end{array}$ & $\begin{array}{c}\mathrm{S} 13, \mathrm{~S} 8, \mathrm{~S} 34 \\
\mathrm{~S} 10, \mathrm{~S} 9, \mathrm{~S} 11, \mathrm{~S} 14\end{array}$ & $\begin{array}{l}\mathrm{S} 31, \mathrm{~S} 8, \mathrm{~S} 10, \mathrm{~S} 12, \\
\mathrm{~S} 11, \mathrm{~S} 13, \mathrm{~S} 14\end{array}$ & ------- & $\begin{array}{l}\text { S9, S10,S14, } \\
\text { S12, S31, S9 }\end{array}$ \\
\hline & $\mathrm{D}_{9}$ & S20, S18, S22 & $\begin{array}{l}\text { S20, S21, S15, } \\
\text { S22, S18 }\end{array}$ & $\begin{array}{l}\text { S20, S21, S16, } \\
\text { S17, S22 }\end{array}$ & $\mathrm{S} 15, \mathrm{~S} 22, \mathrm{~S} 16$ & ------- \\
\hline & $\mathrm{E}_{10}$ & $\begin{array}{c}\mathrm{S} 28, \mathrm{~S} 32, \mathrm{~S} 25, \\
\mathrm{~S} 30\end{array}$ & $\begin{array}{l}\text { S26, S30 S27, } \\
\text { S24,S37 }\end{array}$ & S30, S28, S32 & S26, S24 & --------- \\
\hline
\end{tabular}

As can be observed in the code of using mathematical symbols in Table 5, the students at all levels used symbols. The use of words by level E students is limited. There is no significant increase in their use of words. Even though the use of mathematical words by level D students is not at the expected level, it is more intensive when compared to level E students. The use of mathematical words by level B and level C students increased in time. As for level A students, they used mathematical words at the expected level at the beginning, during, and at the end of the study. With respect to the code titled 'drawing mathematical figures', it was revealed that level E students did not draw a sufficient amount of figures. Level D students showed a noticeable degree of progress in drawing figures. Level B and level C students drew figures more intensively towards the end of the study. Level A students produced drawings of figures at every stage of the study. In terms of the code titled 'using unique words and symbols', students at levels D and E are observed to have used unique words and symbols. However, there was no increase in the intensity of their use of these words and symbols. Moreover, even though the students at levels $\mathrm{B}$ and $\mathrm{C}$ had used unique words and symbols at the beginning of the study, they did not continue doing so toward the end of the study. Among level A students, apart from one student, use of unique words was not observed. As regards the code titled 'Using different symbols', it can be maintained that the students at levels D and E are not aware of the use of different symbols, while those at the other levels are.

Sample quotations from the students' written responses to the activities in relation to the theme of 'using mathematical language' are presented in Table 6. 
Table 6. Samples from student responses under the theme of 'use of mathematical language'

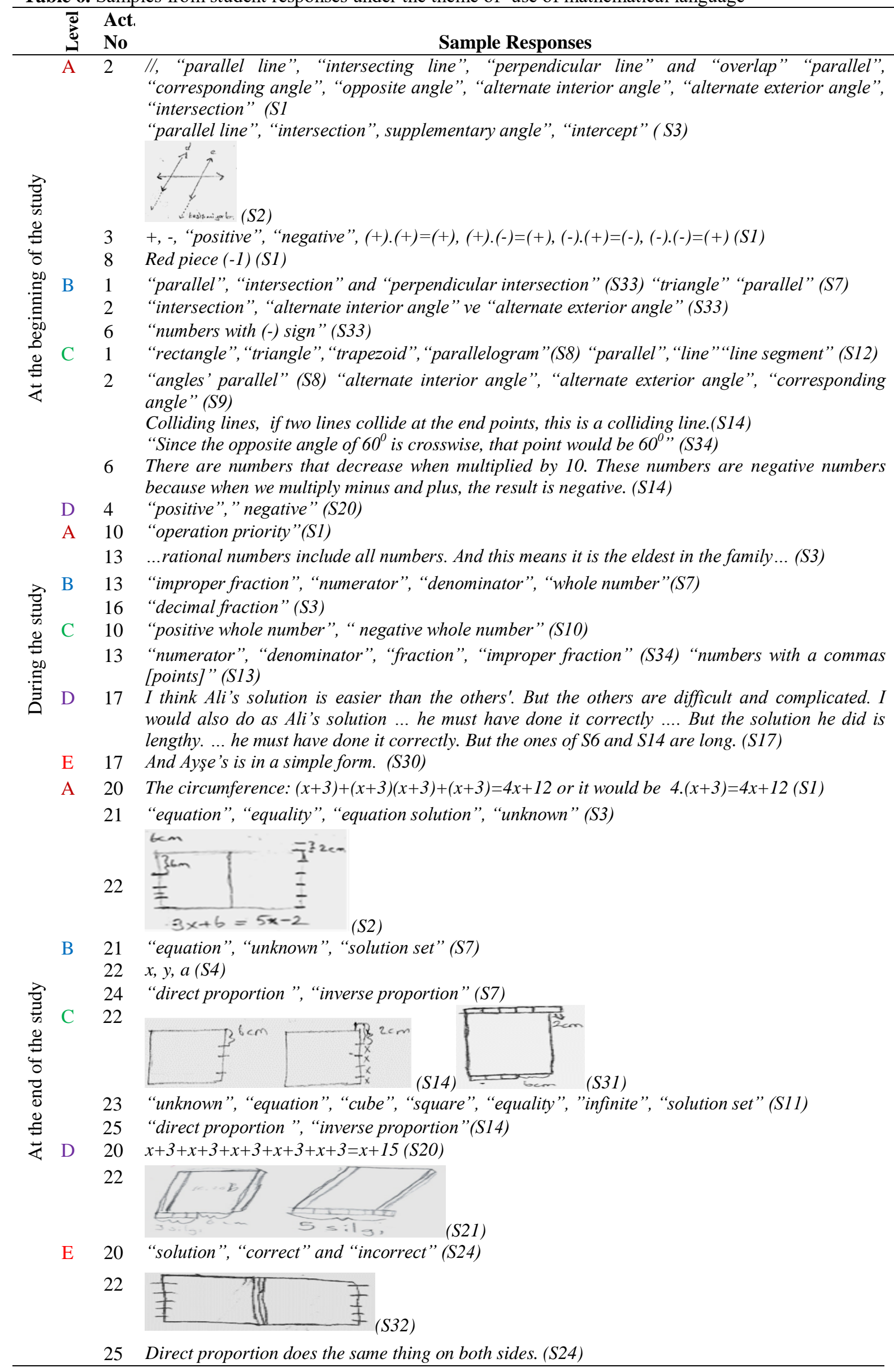


As can be observed in Table 6, in activity 2, S1 from level A used the symbol "//" to show that the two lines were parallel. While writing a response to activity 3 , S1 showed to the other students at this level the "+" and "-_" symbols next to the words, positive and negative, and that the results of a multiplication operation between these could be positive or negative. While writing a response for activity 8 , implemented during the study, S1 first showed each of the negative whole numbers with the symbol " 1 ". In activity 20 at the end of the study, S1 calculated the circumference and the area of the square by making the statement below regarding the 3-unit increase in the side of the square. The student could indicate the circumference of the square in two different ways by using symbols. A student at this level, S1, intensively used the words "parallel line", "intersecting line" and "perpendicular line" in relation to the topic in the first activity of the study. This student also used the word "overlap". While writing an explanation in activity 2, S1 used the words "parallel", "corresponding angle", "opposite angle", "alternate interior angle", "alternate exterior angle", "interception". Different from the other students, S1 used the mathematical word "operation priority" in activity 10 implemented during the study. Examples of the mathematical words that S3 used in the first two activities on lines and angles are "parallel line", "interception", "supplementary angle", "intercept". Even though these were early stage activities, the student is observed to have used mathematical words. In activity 21 toward the end of the study, S3 used the words "equation", "equality", "equation solving", "unknown" etc.

When the figures drawn by the students were examined, in activity 2, S2 stated that lines d and e were parallel to each other and that no matter how much they were extended, they would not intersect. S2 drew a figure in activity 22 toward the end of the study. Apart from S3, no student at this level was observed to have used unique words. As for S3, while writing a response to the question in activity 13 , s/he used the expression 'the eldest of the family' to refer to the rational number set to indicate that it included rational numbers, whole numbers and natural numbers.

As indicated in Table 6, S33, a level B student, did not use the required mathematical words in the first activity of the study. However, it was observed that the study used the words "parallel", "intercept" and "perpendicular intercept". In activity 2., the same student used the words "intersection", "alternate interior angle" and "alternate exterior angle", and in activity 6, s/he wrote the expression "number with (-) sign" instead of "negative whole numbers". However, in activity 16, implemented during the study, S33 mentioned "decimal fraction" with the correct usage. Similarly, S7, again a level B student, used an irrelevant word - "triangle" in the first activity of the study. However, s/he also used the word "parallel", which was relevant to the topic. The student did not use irrelevant words in the other activities. While writing a response in activity 13, implemented during the study, S7 used the words "improper fraction", "numerator", "denominator", "whole number". While writing responses to the questions in the activities toward the end of the study, the same student frequently used topic-related words, such as "equation", "unknown", "solution set", "direct proportion", and "inverse proportion". S4, another level B student, stated that such letters as $\mathrm{x}, \mathrm{y}$ and a could be written in place of an unknown and then continued to state that letters $y$ and a would bear the same meaning as $\mathrm{x}$. The fact that the student mentioned that $\mathrm{y}$ and a would bear the same meaning as $\mathrm{x}$, which is used more frequently for unknowns may indicate that the student is aware of the use of mathematical symbols.

As indicated in Table 6, in activity 1 at the beginning of the study, S8, a level C student, used words that were irrelevant to the topic, namely "rectangle", "triangle", "trapezoid" and "parallelogram". In a later activity, while writing about parallelism between lines, s/he stated that the "angles are parallel". However, no such incidences by this student were encountered in the other activities. Even in activities where the student produced wrong answers, s/he did not use irrelevant words. When compared to the students with a low and very low level of academic achievement, level C students were found to be using mathematical words more intensively in the initial activities. To illustrate, in the initial activities, such mathematical words as the following were used: "parallel", "line", "line segment", "alternate interior angle", "alternate exterior angle", "corresponding angle" etc. In the activities implemented during the study, again there was more intensive use of mathematical words when compared to the students with low and very low levels of academic achievement. Such examples of words are "cross multiplication", "positive whole number, "negative whole number", "numerator", "denominator", "fraction", "improper fraction" etc. In the activities at the end of the study, again there were uses of mathematical words: "unknown", "equation", "direct proportion", "inverse proportion", "cube", "square", "equality", "infinite", "solution set". The students at this level were also found to have used unique words at the beginning of the study. In activity 1, S14 used the unique term "colliding line" instead of intersecting line. Again the same student used the unique expression "numbers with (-) sign" instead of negative numbers in activity 6 . S13 used "numbers with commas [points]" instead of decimal numbers in an activity implemented during the study. In activity 2, S34, a student at the same level, established an association between the words "opposite angle" and "crosswise" to explain the concept of opposite angle. However, in later activities, no such incidences were observed.

As indicated in Table 6, in activity 4, S20, who was a level D student, preferred to use the words "positive" and "negative" instead of "+" or "-“. The students preferred to use words rather than symbols. In activity 20 
toward the end of the study, even though S20 used the symbols accurately, s/he arrived at the wrong answer in the operations between these symbols. While the student added the numbers in this activity, s/he did not add the $\mathrm{x}$ variable. It was observed that was an increase in the figures drawn by level D students. However, sometimes they did not establish an association between the question and the figure. In activity 22 toward the end of the study, S21 established an association with one of the figures, but could not with the other. Although, in the picture on the left, the student showed that the measurement of the short side of a book fell $6 \mathrm{~cm}$ short when measured with an eraser by flipping it is placed tip to tip three times, in the picture on the right, s/he was not able to show that $2 \mathrm{~cm}$ was left over when the eraser was flipped over sideways five times. When the writing of level D student writings were examined with respect to the code of 'being aware of using different symbols', it was observed that S17 had not mentioned the representations in activity 17, which was related to different representations of rational numbers. This shows that the student made interpretations by looking at the solutions of the questions in the activity.

The use of words by level E students was limited and there was not much variety in the words level E students used. The words used by the students while writing responses in the activities generally consisted of words that were used to express the questions on the worksheet. The students at this level were observed to have used irrelevant words at the beginning of the study, and there was not much progress in the use of mathematical words. For example, toward the end of the study in activity 20, in which a lot of mathematical words could be used, S37 hardly used any mathematical words. Similarly, another student at the same achievement level only used the words 'solution', 'correct', and 'incorrect' in the same activity.

Some of the level E students were did not draw any figures, while some of them did so but did not associate them with the activity. The figure drawn by S32 in activity 22 toward the end of the study is presented in Table 6. The student merely tried to draw a picture of a book. Some of the students at this level used unique words. To illustrate, in activity 25, implemented toward the end of the study, S24 wrote, "a direct proportion does the same work on both sides." Even though the student had made an inaccurate explanation, while one of the two quantities decreased, the other increased. To explain that rule that one increased as the other increased as well, the student used unique expressions. Similarly, as observed in the example in Table 6, S30 explains the operation of the conversion into improper fraction with the word "simplicity" in activity 17.

S5, a level B student, was observed to be aware of different symbols. In activity 14, S5 stated that the numbers $6 / 9,18 / 27$, and 54/81 were equal to the rational number $2 / 3$. Similarly, in activity 17 , the same student stated that improper fractions and mixed fractions could be expressed in terms of whole numbers and proper fractions. S33 and S4, who were at the same achievement level, also gave similar responses to the same activities. In activity 22 toward the end of the study, S4 stated that symbols " $y$ " and "a" could be used with the same meaning as " $\mathrm{x}$ ".

In activity 8, S14, a level $\mathrm{C}$ student, wrote $(+12):(+2)=(+6)$ as the representative model. Here, the student did not take into consideration that the red pieces needed to represent negative numbers. In activity 19 toward the end of the study, the same student stated that the expressions $(2 x)^{3}$ and $2 x^{3}$ were not the same: "in the first one, it says 'cube the parenthesis' and $2 \mathrm{x}^{3}$ says only 'cube it'. That's why both of these are equal." The student was found to have used the symbols accurately. S14, a level C student, drew a parallelogram in the first activity and wrote an explanation next to the figure: "the parallel is equal to the line, that is, to this figure because they lie horizontal to each other, it is a parallel line." However, the student could not establish a sufficient association. In activity 18 , somewhere in the middle of the study, the same student drew circles and wrote the fractions within this circle. However, s/he placed the 5 people in the problem that did not support any team in the circle as well, just like s/he did with the fractions. The student used the fractions and number 5 with the same logic. However, fractions such as 5/12 and others that were given in the question was in the form of students' $5 / 12$. That is, it is not the same as what the whole number 5 expresses. The student is seen here to have tried to establish an association by drawing a figure. However, s/he was not able to do this at the expected level. In activity 22 toward the end of the study, the same student drew the picture presented in Table 6. In this picture, the student has drawn a figure to establish an association between the question and itself. Similarly, in activity 22, S31, a student at the same level drew the picture depicted in Table 6. Different students at a low and very low academic achievement levels, the student, who added the eraser 3 times and 5 times on different but equal sides of the same figure, has has been able to show in this picture the falling short and being too long in the two cases, respectively.

In activity 4, implemented at the beginning of the study, S17, a level D student, did not use any symbols. Instead, s/he used words to make his/her explanations. Some of the students at this level were found to have used words within the same topic interchangeably. For example, they used the word "corner" instead of "side", the word "angle" instead of "angle measure", and the word "perpendicular line" instead of "right angle". However, toward the end of the study, this kind of word usages were not observed. 
Level E students used symbols. However, the way the symbols were used were inaccurate. They could not associate mathematical content and the symbols accurately. Students at this level generally used the symbols they learned in the previous years more accurately. They rarely used the new symbols (x, y etc.) they learn. Moreover, there were errors in the use and operations of the variable symbol. For example, S25 could not identify the difference between the variable symbol $x$ and the numbers. Adding " $x$ " and the number " 3 ", s/he wrote the answer as " $4 \mathrm{x}$ ". Similarly, s/he added " $\mathrm{x}$ " and " 4 " and wrote the answer as " $5 \mathrm{x}$ ". The student could not identify the difference between the numbers and symbols.

\subsubsection{The Mean of the Scores the Students Received from the Theme of 'Using Mathematical Language' on the $A S R$}

The means of the scores the students received from the Theme of "Using Mathematical Language" on the ASR are presented in Figure 6.

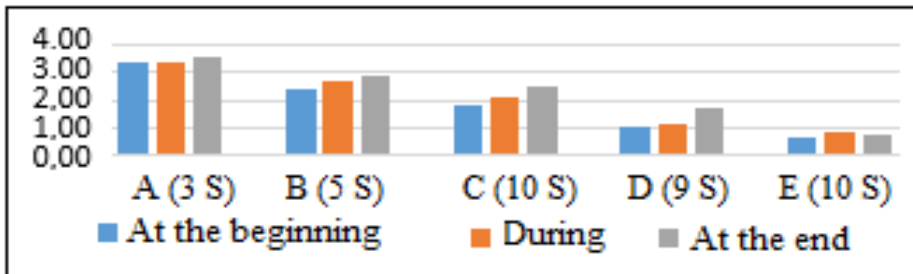

Figure 6. The means of the scores the students obtained from the theme of 'use of mathematical language' on the ASR

As depicted in Figure 6, even though there is a difference between the mean scores of the level A and E students at the beginning and during the study, there is no distinct difference between the mean scores at the end. This could indicate that writing activities do not distinctly develop the use of mathematical language of the students in the very low academic achievement group.

It is also observed in Figure 6 that there has been a distinct increase in the means of the scores of the students at levels B, C, and D received at the beginning, during and at the end of the study. Hence, it can be deduced that writing activities contribute to the use of mathematical language of students whose academic achievement levels are low, average, high or very high.

Finally, according to Figure 6, in the theme of 'use of mathematical language', the most unsuccessful group across all stages of the study can be said to be the group with a very low academic achievement level. Furthermore, it was observed in the activities implemented in all stages of the study (beginning, during, end) that there were differences between the mean scores of the students who were grouped in accordance with the achievement levels. Thus, it can be claimed that the mathematical language these students used varied in accordance with their academic achievement levels.

\subsection{Findings Regarding the Theme of "Mathematical Algorithm and Calculations"}

The written responses given in the activities by the students, who were grouped based on their academic achievement levels, were analyzed under the theme 'mathematical algorithm and calculations' and the codes that were established during this analysis are presented in Table 5. During the presentation of the findings, the expressions 'forming algorithms' and 'making calculations' were used. 'Forming algorithms' refers to all the processes intended to be made while providing a response in an activity and 'calculations' are the operations done during these processes. Thus, when providing a response in an activity, initially algorithms are formed and then calculations are done. In an inaccurately formed algorithm, even if calculations are correct, the required answer might be wrong.

As can be observed in Table 7, with respect to the code of 'making calculations that are incomplete, irrelevant or based on visual perceptions', level E students were found to have made calculations that were incomplete, irrelevant or based on visual perceptions in all stages the study. As for level D students, though not as much as level E students, they were also found to have made incomplete and irrelevant calculations in all stages of the study. Progress was observed in the calculations made and algorithms formed by level C students, whereas no progress was observed in level A and level B students.

In terms of the code 'being able to develop a different algorithm and calculation method', it was observed that apart from one student, none of the level E students had used a different algorithm or calculation. Similarly, a limited number of level C and level D students had used different calculation and/or algorithm; however, use of different algorithms and calculations was observed in the responses made by level A and level B students in the activities implemented during and at the end of the study. As presented in Table 7, only two students checked the accuracy and rationality of the result they had found. 
Table 7. The students within the codes formed under the theme of mathematical algorithm and calculations

\begin{tabular}{|c|c|c|c|c|}
\hline & ర్ల & $\begin{array}{l}\text { Making calculations that are } \\
\text { incomplete, irrelevant or } \\
\text { based on visual perceptions }\end{array}$ & $\begin{array}{l}\text { Being able to develop } \\
\text { different algorithm and } \\
\text { calculation methods }\end{array}$ & $\begin{array}{l}\text { Evaluating the solution } \\
\text { (checking the accuracy and } \\
\text { rationality of the solution) }\end{array}$ \\
\hline \multirow{5}{*}{ 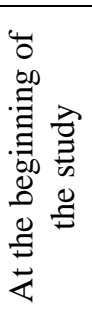 } & $\mathrm{A}_{3}$ & ------ & Ö1 & Ö1 \\
\hline & $\mathrm{B}_{5}$ & S33, S6,S4 & $\mathrm{S} 33, \mathrm{~S} 5$ & ------- \\
\hline & $\mathrm{C}_{10}$ & $\begin{array}{c}\text { S10, S12, S34, S9,S11, } \\
\text { S14,S8,S31 }\end{array}$ & S8, S34 & \\
\hline & $\mathrm{D}_{9}$ & $\begin{array}{l}\mathrm{S} 21, \mathrm{~S} 35, \mathrm{~S} 17, \mathrm{~S} 16, \mathrm{~S} 19 \\
\mathrm{~S} 21, \mathrm{~S} 18, \mathrm{~S} 22\end{array}$ & S16 & ------- \\
\hline & $\mathrm{E}_{10}$ & $\begin{array}{c}\mathrm{S} 23, \mathrm{~S} 32, \mathrm{~S} 28, \mathrm{~S} 26, \mathrm{~S} 24, \mathrm{~S} 25, \mathrm{~S} 3 \\
6, \mathrm{~S} 29\end{array}$ & S36 & ------- \\
\hline \multirow{5}{*}{ 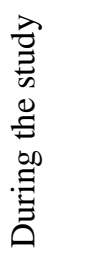 } & $\mathrm{A}_{3}$ & 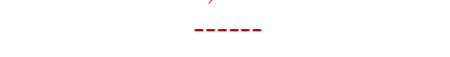 & $\mathrm{S} 1, \mathrm{~S} 2, \mathrm{~S} 3$ & ------- \\
\hline & $\mathrm{B}_{5}$ & S6,S4 & $\mathrm{S} 5, \mathrm{~S} 33, \mathrm{~S} 7$ & ------- \\
\hline & $\mathrm{C}_{10}$ & S12, S34, S14, S11 & S8, S10, S14 & S31 \\
\hline & $\mathrm{D}_{9}$ & S20, S17, S16, S21, S15, S19 & $\mathrm{S} 22$ & ------- \\
\hline & $\mathrm{E}_{10}$ & $\begin{array}{c}\mathrm{S} 26, \mathrm{~S} 25, \mathrm{~S} 29, \mathrm{~S} 23, \mathrm{~S} 36, \mathrm{~S} 32, \mathrm{~S} 2 \\
\mathrm{~S} 8, \mathrm{~S} 30\end{array}$ & ------. & ------- \\
\hline \multirow{5}{*}{ 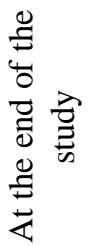 } & $\mathrm{A}_{3}$ & ---- & $\mathrm{S} 2, \mathrm{~S} 3$ & ------- \\
\hline & $\mathrm{B}_{5}$ & S6,S4 & $\mathrm{S} 33, \mathrm{~S} 5, \mathrm{~S} 4$ & -------- \\
\hline & $\mathrm{C}_{10}$ & $\mathrm{~S} 34, \mathrm{~S} 14$ & S8, S31 & ------- \\
\hline & $\mathrm{D}_{9}$ & S16, S35, S20, S19, S15, S18 & S15 & ------- \\
\hline & $\mathrm{E}_{10}$ & $\begin{array}{l}\mathrm{S} 25, \mathrm{~S} 29, \mathrm{~S} 23, \mathrm{~S} 36, \mathrm{~S} 28, \mathrm{~S} 26, \mathrm{~S} 3 \\
2, \mathrm{~S} 24, \mathrm{~S} 30\end{array}$ & -------- & ------ \\
\hline
\end{tabular}

There are hardly any insufficiencies in the calculations made by level A students. Moreover, the calculations made by these students in all stages of the study are not irrelevant nor based on visual perceptions. For example, in activity 12, S1 did the calculation depicted in Figure 7 below:

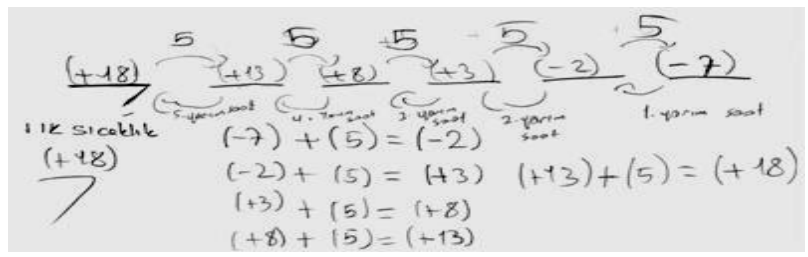

Figure 7. A response by $\mathrm{S} 1$ produced during the study

It can be observed in this picture that the student has shown that there was a 5 degree drop in temperature every half hour and has tried to find the initial temperature based upon the (-7) degree temperature, which was formed at the end of 3 hours. When making the calculation, the student added 5 degrees to the final temperature. Hence, there was a deficiency in his/her calculation. The expected answer was 23 degrees. The students at this level were able to put forward different solution algorithms. One of these students, S1, used a more practical solution method by not including mixed fractions into the calculation as they would be larger than the others instead of equating the denominators of all the rational numbers. The same student also examined the other numbers among themselves and found the results. S3, another student at this level, stated, while writing a response in activity 15, that a number line needed to be divided into two to find the place of 0 before rational numbers are placed on the number line. That is, the student thought that the exact midpoint between -2 and 2 would be " 0 ". With the same rationale, s/he found the numbers corresponding to the other points on the line. Thus, it can be asserted that the students in level A can develop different algorithms to the questions in the activities.

Even though there were deficiencies in the responses given in the writing activities by level B students at the beginning, during, and at the end of the study, these were not as much as the deficiencies observed in the responses of the students at levels C, D, and E. Moreover, the calculations the level B students made were not irrelevant nor based on visual perceptions. For example, even though the algorithm formed by S4 in activity 3 , implemented at the beginning of the study, was correct, s/he subtracted 21 from 16 and found a wrong answer: -4 instead of -5 . In activity 9, the same student could find the non-given term in the first and second list in his/her response, but could not calculate the term that was not given in the third list. Similarly, while calculating the circumference of the square in activity 20 , implemented at the end of the study, the same student miscalculated the length of the two sides to be " $x+6$ " and then added " $x+6$ " and " $x+6$ " and arrived at a wrong answer: " $x+12$ ". However, in the same activity, the student was able to calculate the area of the square accurately. In the "ratio 
and proportion 2' activity, S4 answered the questions accurately by forming an algorithm as follows: “...3 taps fill a pool in 5 hours. 4 taps would fill the pool in a shorter period of time. While one increases, the other decreases... it is inverse proportion..." In the activity titled "Equations-2", implemented at the end of the study, S4 formed the equation accurately appropriate to the given situation, but did a wrong calculation and found the unknown number as (-2). The student used the $\mathrm{x}$ symbol for the length of the eraser in this response. Therefore, the result should not have been a negative whole number. The student did not think about whether or not the result was logical.

Apart from two students, level C students were observed to have made progress in the calculations they did and the algorithms they formed. To illustrate, in activity 3, implemented at the beginning of the study, S11 found that the drop in temperature in 7 days would be "-21", but later formed an inaccurate algorithm and multiplied 21 by 16 instead of subtracting them from each other. The same student could not answer the question in activity 5 due to forming an inaccurate algorithm. In activity 9, even though S11 could accurately calculate the term in the first and second list given in the question, s/he could not form an algorithm for the third list. This same student could not form accurate algorithms in activities based on problem solving with whole numbers implemented during the study and thus could not answer the question. However, in activity 22, implemented at the end of the study, s/her could form accurate equations to write: " $3 x+6=5 x+2$ ".

Even though some of the level D students formed incorrect algorithms and made inaccurate calculations in the activities at the beginning of the study, in later stages of the study, only deficiencies in their calculations were observed. Of these level D students, S18 found that the temperature would drop to 36 degrees, but could not do the rest of the calculation in activity 11 , implemented somewhere in the middle of the study. The student's calculation was incomplete. The same student multiplied the algebraic expression " $2 \mathrm{x}$ " by " $2 \mathrm{x}$ " and arrived at a wrong answer: " $4 \mathrm{x}$ ". Even though the student had multiplied the correct algebraic expressions, the multiplication operation could not be done correctly. S18 calculated the length of the eraser while solving the problem in activity 22 . To find the length of the book, s/he should have placed this number in the equation. Hence, there was a deficiency in the student's solution. In the activity that followed, the same student found the correct algebraic expression, " $x+4$ ", representing the circumference of the square, but found " $x+12$ " instead of " $4 x+12$ " as the addition of these expressions. The student had done an inaccurate calculation. Similarly, there are deficiencies in the algorithms and calculations made in the ratio and proportion activities. The students at this level did not consider whether or not their results were logical. For example, in activity 8, S15 inaccurately stated the mathematical operation representing the model as $(-12)+(-12)=(+24)$. The student could not consider that the pieces represented negative numbers and thus the result had to be a negative number.

With respect to the code 'making calculations that were incomplete, irrelevant or based on visual perceptions', in activity 11, S29, a level E student, first found that the temperature difference between -22 and 14 was 36 . Then s/he divided 36 into 9 and calculated the temperature for 1 hour. However, the student's answer was incomplete since the question asked for the temperature at the end of 5 hours. Even though it was indicated in activity 20 that a 3 -unit increase in in the length of the square would create a new square having a length of $x+3$, the same student calculated the circumference of the new square as " $3+3+3+3=12$ ". In activity 3 , similar to his/her peers in this level group, S24 made calculations that were based on visual perceptions and thus consisted of numbers being summed and subtracted among themselves. It was indicated in the activity that the weather temperature was 16 degrees and there was a drop of 3 degrees each day. The student subtracted 3 from 16 and found 13 . To find the temperature at the end of the 7 th day, s/he subtracted 7 from 13 and found the result to be 6. The algorithm used in this response was inaccurate. At later stages in study, in activities 11 and 12, which were related to constructing and solving problems, the same student did similar calculations. All of the students at this level of academic achievement were found to have done calculations that were incomplete, irrelevant or based on visual perceptions across all stages of the study. Moreover, in relation to the code of 'being able to develop a different algorithm and calculation method', a finding was obtained only in the response of one student among the students at this level. S36 used a different calculation method in activity 3 at the beginning of the study. The student expressed the decrease in temperature for 7 days by subtract seven items of 3 from 16, the initial temperature. Apart from S36, none of the students at this level was observed to have used a different algorithm or calculation.

\subsubsection{The Means of the Scores the Students Received from the Theme of 'Mathematical Algorithm and Calculations' on the ASR}

The means of the scores the students received from the theme of "mathematical algorithm and calculations" are presented in Figure 8.

As depicted in Figure 8, there is no distinct difference between the scores of level A (very high level of academic achievement) and level $\mathrm{E}$ (very low level of academic achievement) at the beginning, during, and at the end of the study. This could indicate that writing activities do not distinctly develop the use of mathematical algorithms and calculations of the students in the very low academic achievement group. 


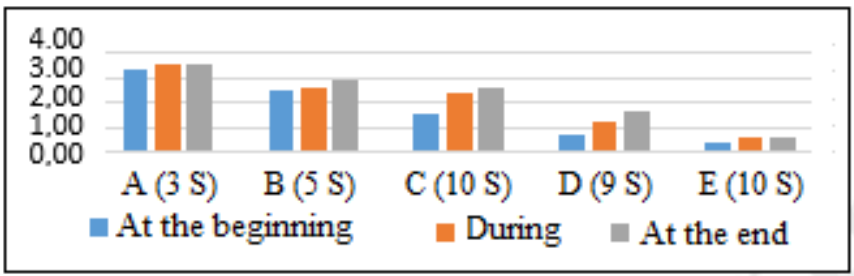

Figure 8. The means of the scores the students obtained from the theme of 'mathematical algorithm and calculations" on the ASR

It is also observed in Figure 8 that there has been a distinct increase in the means of the scores of the students at levels $\mathrm{C}$ (average level of academic achievement) and D (low level of academic achievement) received at the beginning, during and at the end of the study. Hence, it can be deduced that writing activities contribute to the use of mathematical algorithms and calculations of students whose academic achievement levels are low or average. Moreover, as can be observed in the figure, it can be stated that there has been no distinct increase in the means of the students at level B (high level of academic achievement).

Finally, according to Figure 8, in the theme of 'mathematical algorithm and calcuations', the most unsuccessful group across all stages of the study can be said to be the group with a very low academic achievement level. Furthermore, it was observed in the activities implemented in all stages of the study (beginning, during, end) that there were differences between the mean scores of the students who were grouped in accordance with achievement levels. Thus, it can be claimed that the mathematical algorithms and calculations these students used varied in accordance with their academic achievement levels.

\section{Discussion and Conclusion}

Even though there are numerous definitions and dimensions of cognitive development, the present study addressed three different themes: (1) features of the student explanations, (2) use of mathematical language, and (3) mathematical algorithms and calculations. The students' cognitive developments were analyzed under these three themes.

The students were categorized into five groups based on their academic achievements: very high (A), high (B), average (C), low (D), and very low (E). It can be maintained that writing activities had a positive impact on the explanations of students at levels B, C, and D in terms of their scores earned from the first descriptor of the analytic scoring rubric (ASR), namely "clarity of the explanations." No significant development was identified in the students in the other achievement groups. Similarly, based on the qualitative findings under the detailed, clear and comprehensible code of the theme titled "features of the explanations", it was revealed that the clarity of the responses of the students at levels B, C, and D improved and they made more explicit and clear explanations. Greenes, Ginsburg and Balfanz (2004) stated that with the use of mathematical stories in classes, there was an increased use of mathematical language and higher quality of mathematical explanations. The reason why the related result of the present study was partly inconsistent can be attributed to the configuration and type of writing activities utilized in the present study. Brandenbur (2002) indicated that the use of writing activities in mathematics lessons is important, but is at the same difficult. According to Brandenbur, it may be easy to write a response to a question that asks students to explain how they plan to spend their holiday; however, it is not easy to write about newly learnt complex mathematical concepts. Thus, since the writing activities in the mathematics lesson in the present study necessitated the use of both writing skill processes and mathematical content knowledge, students at level E, who did not show progress, may have found it difficult. Similarly, Akarsu-Yakar and Y1lmaz (2017), who conducted a study in which they examined the mathematical language that 7 th grade students used while converting a real life story related to the domain of algebra, stated that the students with a high level of academic achievement used the written, verbal, and symbolic language accurately while explaining their statements, whereas the students with a low level of academic achievement experienced difficulty while forming symbolic statements and making explanations. In a study by Özkan (2019), in which writing activities were used with 6th grade students in the topic of area measurement, it was revealed that the clarity of the explanations made by the students in the lower achievement group increased over time, but the deficiency in the way they expressed their statements could not be remedied, so they continued to write about irrelevant topics. Moreover, Yalvaç (2019), who conducted a qualitative study to examine the skill of using the mathematical language, which included the ability to use written formal language as a sub-dimension in the learning domain of algebra, it was identified that 8th grade students' use of mathematical language was not at a sufficient level.

In terms of the code of inconsistencies among different explanations made on the same topic and between explanations and mathematical operations, which was examined under the theme titled "features of the explanations", it can be stated that writing activities had a positive impact on students with an achievement level 
of C or D. In other words, it can be claimed that writing activities enabled students at these levels of achievement to reflect on what they have written and internalize their explanations in the course of time (King, Raposo \& Gimenez, 2016; Pugalee, 2001; Seto \& Meel, 2006) because in the beginning, students produce superficial responses, but at a later point in time, they write responses by establishing a connection between the question and mathematical knowledge. Phillis (2020) stated that it would not be easy for students to produce writings relevant to a topic that they could not understand, but that writing could help students to organize their ideas. Accordingly, the fact that the students at levels $\mathrm{C}$ and D did not write irrelevant and conflicting opinions toward the end of the activities in the present study is an indication that these students started to gain a better understanding of the topics.

With respect to the code of 'supporting explanations with examples', it was revealed that the students at level E had not produced any examples to their written explanations. On the other hand, the students at the other levels of achievement, particularly levels $\mathrm{A}, \mathrm{B}$, and $\mathrm{C}$, were found to have produced examples to support the explanations they had made. In writing activities they implemented with 8th grade students, Shield and Galbraith (1998) could observe very little development in students' writings. The students continued to write in the same way as they did so at the beginning. For example, the explanations of the students who did not produce comprehensive explanations at the beginning were still limited toward the end of the activities, and the students who did not provide examples at the beginning continued to avoid giving examples at later stages. Moreover, the students' preferences were more toward writing mathematical operations as opposed to producing expository writings. This could be attributed to the lack of intensive writing implementations by the teachers in the study because even though the research was conducted over a long period of time, the number of writing activities was not high. However, for development to occur, intensive writing activities need to be done because as stated by Vygotsky (1987), writing is different from speaking in all respects and requires a high level of abstraction. Consequently, for development to occur, an intensive and a long-term writing activities is essential (Herrick, 2005; Özkan, 2019).

Based on the analysis of the scores earned from the second category of the ASR — 'use of mathematical words and language' — by the students, categorized according to their academic achievement levels, it can be stated that writing activities have a positive impact on the mathematical words and language used by the students at levels B, C, and D. The qualitative findings of the study revealed that in progress of time, the students at levels $\mathrm{B}, \mathrm{C}$, and D started to use the mathematical language taught in the lessons thanks to the writing activities. This could have stemmed from the fact that since the students were going to doing writing activities, they may have paid closer attention to the mathematical words and symbols used in the lessons, and they may have developed the idea that their teacher would expect more use of formal language. On the other hand, students at level E can be said to be unsuccessful in undergoing this transformation that can be named as transition to formal mathematical language.

In terms of the use of mathematical symbols, the first of the codes under this theme, it can be maintained that writing activities have a positive impact on the use of symbols by students at all levels of academic achievement. However, the symbols cannot be said to have been used accurately and in the write places. Errors could be observed in the responses of students within the Level D and E groups. Errors particularly appeared in the use of the variable symbol. It can be claimed that the higher the level of achievement is, the more consciously the symbol is used and the more meaningful the use of symbols are mathematically. Yeşildere (2010) stated that symbols were signs that supported mathematical explanations, and that just like it is not sufficient to write the correct music notes to form the correct melody, so it is not sufficient to establish mathematical thinking by using mathematical symbols without understanding what they mean.

It was revealed that some of the students at Level D used words within the same area of topic interchangeably. To illustrate, they used the word "corner" instead of "side", "angle" instead of "angle measure", "rational number" instead of "fractional number", "perpendicular line" instead of "right angle" etc. Similarly, Çalıkoğlu-Bali (2002) also observed in his study that the students had used various words interchangeably. In a study by Yüzerler (2013), it was reported that 6th and 7th grade students were deficient in the ability to use mathematical language and that they could not choose the appropriate expressions to while using and explaining concepts. In the present study, it was revealed that the students at levels B and C did not pay much attention to mathematical words in the activities implemented at the beginning of the study, but used them more carefully toward the end of the study. For example, even though in the initial activities, the students uniquely or interchangeably used some words, such as "the angle are parallel" instead of "the lines are parallel", "overlap" instead of "intersection", "angle" instead of "angle measure", and "numbers with (-) sign" instead of "negative integers", at progressive stages of the study these kinds of uses were not observed. It was identified that toward the end of the study, the students were writing words appropriate to mathematical terminology and at the expected level. Moreover, it was revealed that writing activities increased the use of mathematical words of the students at this level. Solomon and O'Neill (1998) expressed that if students used their own words, they would focus more on the mathematics topics covered in class. Hence, writing will necessitate students to pay more 
attention to the lessons, even if not in all cognitive levels. Provided that mathematical language is used appropriately in lessons, it will be possible for abstract concepts to be more easily formed in students' minds and new concepts and knowledge to be accessed by students themselves.

Vygotsky (1987) stated that the reasons for writing are more theoretical than the reasons for speaking and that the act of writing requires analytical behavior which is more conscious and deliberate. Furthermore, Vygotsky observed that scientific activities carried out by children improved writing, that the internal dialogue played an important role in the process of writing, that when particularly students communicate via writing, the words they use are based on the formal (real) meaning of words, and hence, they use more words than they would to express the same ideas in speech (Albert, 2000). Markert (2019) pointed out that when students communicate in writing and speech while learning new mathematical concepts, they can convert words into mathematical symbols. However, in the present study, this was not observed across all academic achievement levels.

In terms of the code of using figures under this theme, it cannot be claimed that writing activities have a positive impact on levels A and E students' skills in drawing figures. The figures drawn by level A students in all stages of the study were related to the topic and at a sufficient level. Level E students' drawings of figures could be observed to have increased toward the end of the study. However, the drawings they made at the end of the study were not associated with the topic. Furthermore, a linear relationship has been identified between academic achievement level and students' act of associating the figures they drew with the topic. The higher the achievement level is, the more the figures drawn are mathematically meaningful and associated with the explanations. Accordingly, it can maintained that there is a linear relationship between achievement level and the use of mathematical figures, and that level E students, who could not express in writing their ideas regarding mathematical concepts and could not present their solutions with models, figures or tables, are deficient in mathematical communication (Banes, 2017). Kramarski and Mizrachi (2004) have expressed that students at higher cognitive levels are successful not only in solving real life problems but also in writing the methods of solution. This finding is consistent with the findings of the present study. Hence, mathematical communication can be considered a sign of higher order cognitive skills, and a parallel relationship can be said to exist between the mathematical communication skill and academic achievement level.

According to the last code under this theme, 'being aware of the use of different symbols', it can stated that levels $\mathrm{D}$ and $\mathrm{E}$ students gave wrong answers in some of the activities because they are not aware of the different uses of symbols. However, levels A, B, and C students are aware of different symbols. To illustrate, in activity 22 toward the end of the study, a level B student stated that the symbols " $y$, a" could be used to mean the same as the " $x$ " symbol. Hence, it could be claimed that there is a directly proportional relationship between achievement level and having awareness. Similarly, Gürbüz and Birgin (2008) have stated that the higher students' levels of education are, the more developed is their ability to make operations by using different methods of representing rational numbers. However, in their study, they did not examine the relationship between the use of writing activities and the increase in students' awareness.

Based on the students' scores obtained from the mathematical algorithm and calculations component, the third category on the ASR, it can be claimed that writing activities have a positive impact on the algorithms and algorithms that levels C and D students establish. Distinct progress could not be identified in the students in the other achievement groups. Davison and Piarce (1990) argue that if teachers use writing activities frequently and in a systematic manner (for example at least once a week), student performances will increase significantly. However, in the present study it was observed that this was not valid for students in all levels of achievement. Similarly, in a study with 4 students on journal writing with prompts, Baxter et al. (2005) found that writing did not contribute to students' mathematical achievement.

In relation to the code titled 'making calculations that are incomplete, irrelevant, or based on visual perceptions' under the last theme formed in the qualitative findings section of the study, positive development was observed in students at levels C and D in their calculations and algorithms. Reilly (2007) has stated that because writing is a process that proceeds slowly, the students participating in writing activities gain a better understanding of mathematical concepts and become more focused on the operations. Thus, within this slowly proceeding process, cognitive development could be observed in students who do not have a high level of mathematical performance.

As regards this code, that development could not be observed in level E students shows that writing activities do not have an impact on level E students' calculations and formulation of algorithms. Since the achievement levels of students at this level are very low, they are deficient in the preliminary knowledge and basic skills needed to produce responses in the activities. Thus, it can be deduced that to be successful in writing activities, students need to have a sufficient level of preliminary knowledge. Riward and Straw (2000) state that for effective writing activities in a class setting, students need to possess certain basic skills and share these with their peers. In addition, Jaafar (2016) has expressed that writing can contribute to the development of higher 
order cognitive skills and enable students to feel more active in the learning process. In the present study, even if all the students were active during the learning process, it is not possible to claim that their higher order cognitive skills showed development.

With respect to the second code, 'being able to develop different structural and calculation methods', different algorithms or calculations could not be observed in any of the level E students, except for one student. This could have prevented the students from focusing on the writing process and developing different solution methods. Similarly, even though only a limited number of levels C and D students were observed to have used different calculations and algorithms, in level B students, particularly in activities implemented in the middle and end stages of the study, the use of different algorithm and calculations is observed. As for level A students, they were found to have used different algorithms and calculations throughout the study. In a study on the relationship between problem solving and writing, Kenyon (1989) reported that students were able to notice different solutions to a problem when they were asked to write about the operations process and their opinions.

As regards the last code, 'evaluating the solution (checking the accuracy and rationality of the solution)', under the last theme, apart from only two students (at level A and level C), none of the students in any of the achievement levels could consider the accuracy and rationality of the results. Albert (2000) stated that including writing into a problem solving task would enable students to not just arrive at the correct answer, but also become focused during the process and thus evaluate the extent to which results are reasonable and logical. However, in the present study, even though the students were able to become more focused during the process, they experienced difficulty in evaluating whether or not the results were logical. This could have stemmed from the fact that the time given to the students for writing was limited. The students experienced difficulty in completing their writing activities within the class time and even had to continue doing the activity during break time sometimes. Therefore, they may have not had the opportunity to review and think about what they had written after completing the activity.

Taking into consideration all the findings, it can be stated that writing activities do not contribute to the development of level A and level E students' higher order cognitive skills to create a significant difference, but have a positive impact on the cognitive development of students at levels B, C and D, and creates a difference in their writing in accordance with their academic achievement level. The first of these findings conflicts with that reported by Knipper and Dugger (2006). Knipper and Dugger (2006) claim that writing can be utilized to increase the performance of students with low levels in mathematics. However, in the present study, it was observed that writing has limited impact on the cognitive development of students with very low achievement levels. This could be attributed to the fact that when writing activities are implemented in a class where there are students of varying academic achievement levels, some of the activities prepared could be, in terms of their algorithm, above the level of the students with very low achievement levels. What's more, journal writing was used in the study of Knipper and Dugger (2006), whereas in the present study, the genre of expository writing predominated journal writing. Hence, this difference in the findings could have stemmed from the difference the writing genre. In a similar study by Roskin (2010), in which the effect of writing on mathematics achievement was examined, the writings were evaluated with the use of a rubric. The rubric scores of 4 students from each mathematics achievement level - high, average, and low - were compared, and it was found that the change in the rubric scores of the student group with low achievement was more than that observed in the scores of the students in the other groups. It may be considered that having only 4 students from each group is insufficient in being representative of the groups. In addition, in grouping the students according to their achievement levels, the researcher only used the scores that the students had received in a test they had taken one year before the study. This may not have been sufficient in grouping students based on their achievement levels.

Even if level $\mathrm{E}$ students were claimed to have made progress beyond their actual development level by receiving their teacher's and friends' assistance, these students could not internalize their knowledge by making use of writing activities. They could not make their explanations more organized, comprehensible, and clear. These students, who received help from their friends and teacher within a social environment during the activities, they were unsuccessful in applying and organizing their ideas and opinions independently. Hence, within ZPP, a new zone in which self-regulatory and self-scaffolding take place (Albert, 2000), it can be claimed that these students cannot independently apply and organize their opinions regarding mathematical concepts and thoughts and cannot gain a deep understanding of mathematics. In brief, these students could not pass from ZPD to ZPP. Even though writing activities are claimed to provide more benefit to students with lower levels of achievement (Roskin, 2010), writing activities may not be a learning method that students with very low academic achievement levels can use (Markert, 2019). Similarly, in a study by Block (2005), it was reported that writing activities could not be an effective teaching method for all students. In this study by Block, students were not examined in accordance with their achievement levels, but it was reported that even though reading and writing activities were done in class, there were students who did not make progress.

That level C students made irrelevant explanations at the beginning of the study, but stopped doing so by producing detailed, clear, and comprehensible explanations at later stages is an indication that these students 
passed on to the ZPP, an zone where these students can self-regulate and self-scaffold. Likewise, that level B and level $\mathrm{C}$ students used unique words and symbols at the beginning of the study but did not do so toward the end of the study, and that an increase was observed in their use of accurate words and figures toward the end of the study prove that students at these levels passed from ZPD to ZPP. O'Connell et al. (2005) reported that as opposed to responses given orally without much thought, writing enables students to test what they have learnt and organize their thoughts in words, and thus, writing provides students with the opportunity to review their thoughts via words and make any revisions needed.

That level D students produced irrelevant explanations, used irrelevant words, or expressed mathematical words inaccurately at the beginning of the study, but started to use mathematical words appropriately and accurately towards the end of the study shows that these students passed on to a zone where they could selfregulate. In brief, it can be asserted that these students passed from ZPD to ZPP. In the present study, even though level E students also produced irrelevant explanations at the beginning of the study but stopped doing so toward the end of the study; however, because these students did not write detailed, clear, and comprehensible responses in the activities at the end of the study, it can be claimed that they were unsuccessful in passing from ZPD, the zone where self-regulation and self-scaffolding take place, to ZPP.

Albert (2000) expressed that Bruner et al. regarded the writing process as the foundation of forming concepts and a means to cognitive development. Thus, writing-to-learn support students' learning processes and help them to construct their knowledge of mathematical thoughts. It encourages students to find their own unique solution methods, associate these with their own ideas, and develop confidence in solving problems independently. Similarly, Teledahl (2016) expressed that writing enables students to reconstruct knowledge by using their own words and is thus a component of learning. However, in the present study, it was revealed that writing activities do not contribute equally to the development of students at different academic achievement levels. Briefly, the cognitive development of students at different levels of academic achievement showed variation. In conclusion, writing activities were found to be of benefit for the cognitive development of students at particularly average or near-average levels of academic achievement (levels B, C, and D).

\section{Recommendations}

Teachers who are to use write-to-learn activities in their lessons are recommended to have students with an average or near-average level of academic achievement to gain maximum efficiency from their lessons.

When the numerous contributions that writing activities have to student learning are taken into consideration, it is clear that the textbooks used in Turkey should be examined to see whether they also support mathematical communication. If not, it is important that the deficiencies be remedied because writing-to-learn activities alone may not be sufficient. Moreover, more place should be given to how to implement writing-to-learn activities within the mathematics curricula. It is not an easy process, considering that students cannot immediately adapt to the use of writing-to-learn activities, which enable students to reflect more on what they have written, to be more focused, and to gain a better understanding of the topic addressed. Hence, it is recommended that writing-tolearn activities be implemented consistently over a long period of time.

Writing activities provide teachers with enriched and valuable information about what is going on in class. Hence, primary school mathematics teachers can be informed about writing activities, which are not difficult nor costly, and enable them to provide effective mathematics education in their classes.

Among a large variety of writing genres, journal writing and expository writing activities were utilized in the present study. Other studies can address other genres of writing. Development in writing may have an impact on mathematical speaking and mathematical literacy, which are other elements of mathematical communication. Therefore, it is recommended that studies be conducted to reveal the relationship between mathematical writing, mathematical literacy and speaking. 
Appendix 1. Examples of Activities

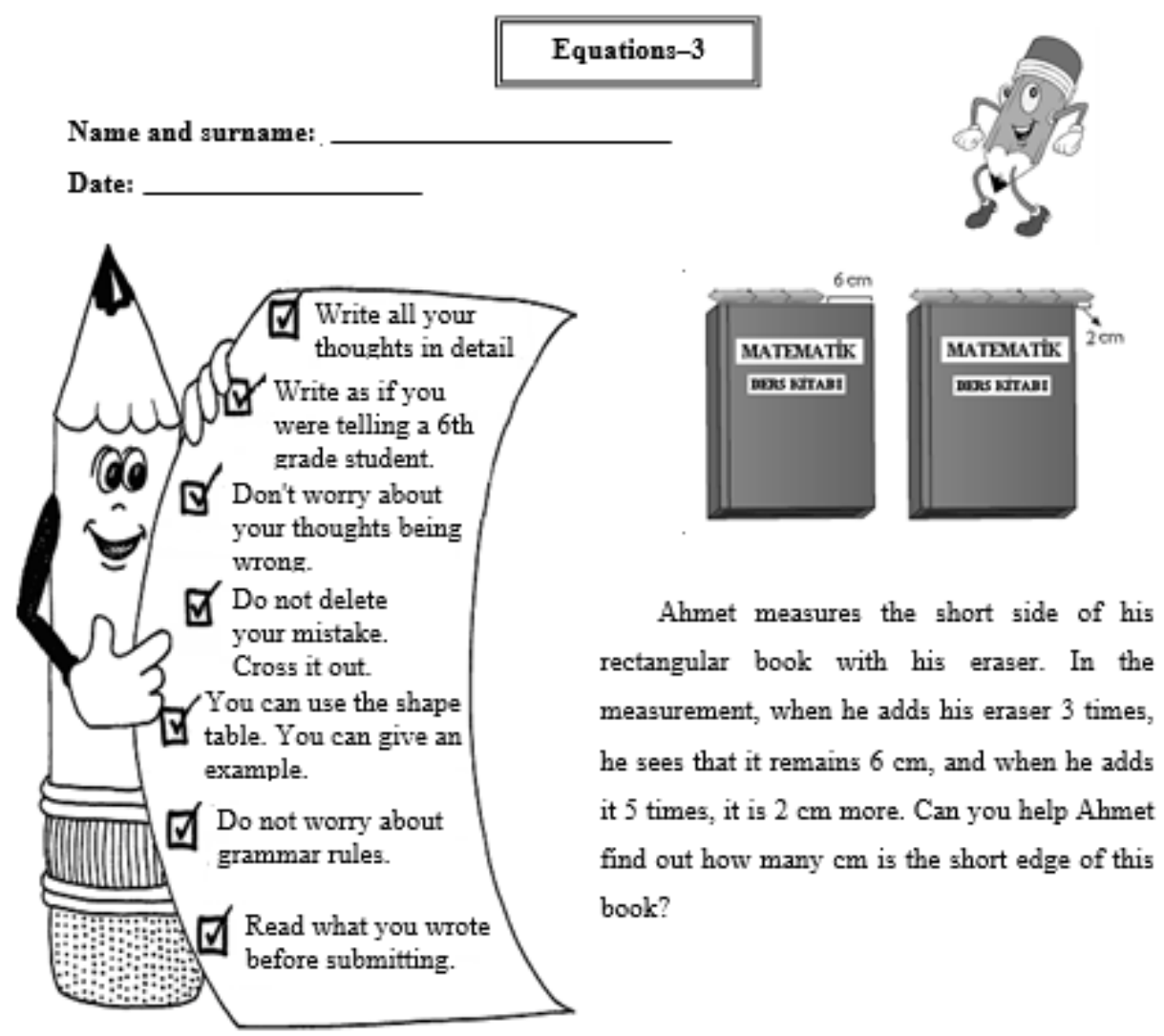

MY MATH DIARY - 3

Name and surname:

Date:

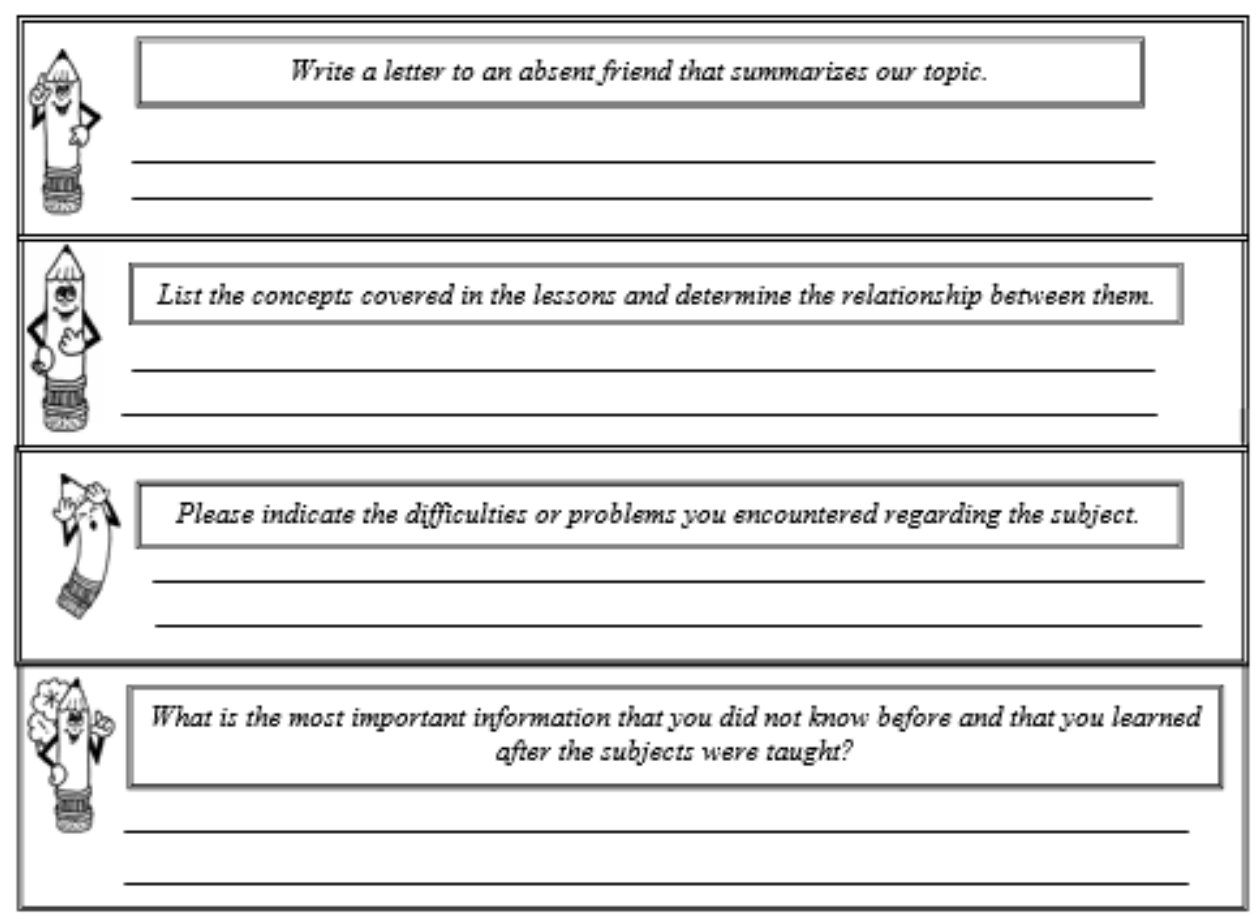




\section{Yazma Uygulamaları İle Destekli Matematik Derslerinde Öğrencilerin Bilişsel Öğrenmelerinin İncelenmesi}

\section{Giriş}

Matematik, günlük kullanılan dil ile birebir örtüşmeyen, kendine özgü kavramları, terimleri, simge ve sözcükleri olan evrensel bir dildir (Hoffert, 2009). Konuşma, dinleme, okuma ve yazma dilin öğeleri arasındadır (Shanahan, 2006). Dil öğrenirken konuşma ve yazma önemli bir işlev görmektedir (Güneş, 2013). Matematik de bir dil olduğundan matematiği anlamada, yorumlamada ve düşünceyi harekete geçirmede konuşmanın ve yazmanın önemi büyüktür (Baki, 2008). Öğrencilerin matematik bilgilerini kendilerinin yapılandırdığı ve kavramları daha iyi öğrenerek içselleştirdikleri süreçte kullandıkları yöntemlerden birinin, matematik dilini karşıllklı konuşma ve yazma olduğu ifade edilmektedir (Albert, 2000; Pugalee, 2004). Ancak yazma eylemi, eş zamanlı olarak el, göz ve beyni kullanmayı gerektirdiği için diğer dil becerilerine göre daha fazla çaba gerektiren bir özelliğe sahiptir (Demir, 2013).

Geleneksel olarak yürütülen matematik öğretiminde, yazı yazma ve matematik birbirinden ayrı olarak düşünüldüğü için, matematik sınıflarında yazı yazmayı kullanmak, sıra dışı olarak görülebilir (Liedtke ve Sales, 2001). Hatta yazı yazmak Türkçe dersiyle, hesaplamalar yapmak matematik dersiyle özdeşleşmiş olarak düşünülür (Reilly, 2007). Bu nedenle, matematik derslerinde yazma uygulamalarını kullanma süreci hızlı gelişmemiştir (Herrick, 2005). Applebee ve Langer (2006) yazma uygulamalarının daha çok fen ve sosyal bilimlerle ilgili derslerde kullanıldığını, matematik derslerinde kullanımının düşük olduğunu belirtmiştir. Yalvaç'ın (2019) cebir öğrenme alanında matematiksel dili kullanma becerilerini incelediği araştırmasında, öğrencilerin matematiksel dil kullanımlarının yeterli düzeyde olmadığını tespit etmiştir. Oysa birçok araştırma, yazma uygulamalarının matematik programında kullanılmasını desteklemektedir (Gibson ve Thomas, 2005; Meier ve Rishel, 1998; Ntenza, 2006; O'Connel ve ark., 2005; Pugalee, 2004).

Amerika'da ve İngiltere'de 1960'lı yılların sonunda başlayan daha sonra Kanada ve Latin Amerika ülkelerine yayılan "Müfredatta Yazmak" (Writing Across Curriculum [WAC]) projesi ile İngilizce dışındaki diğer derslerde de öğrenme amaçlı yazmanın kullanılması amaçlanmıştır (Uğurel, Tekin, Yavuz ve Keçeli, 2009; Keathley, 2018). WAC hareketinin genel olarak başarılı olduğunu belirtilmesine rağmen, onun yayılmasında beklenmeyen bazı problemlerin olduğunu ifade edilmiştir. Birincisi; bazı matematik konularının yazmaya elverişli iken bazılarının çok elverişli olmaması, dolayısıyla bazı matematik öğretmenlerinin yazmayı sadece hikâye problemlerinde kullanabileceklerine inanmaları, ikincisi; resmi olmayan bu yazma çeşidinde yanlış yazımların, kötü cümle yapılarının resmi iletişim olarak kullanılması fikrinin bazı öğretmenleri rahatsız etmesi, üçüncüsü; kalabalık sınıflarda uygulanmasının zor olmasıdır (Fulwiler, 1984). Tüm bu zorluklara karşın Amerika'da yazma etkinlikleri bütün sınıf seviyelerinde kullanılması önerilmiştir (National Council of Teachers of Mathematics [NCTM], 1989). 1960'lı yıllardan günümüze kadar birçok araştırmacı bir konu ile ilgili yazı yazmanın, o konuyu öğrenmeyi desteklediğini iddia etmiştir (Galbraith ve Baaijen, 2018). Bu iddia yazmanın günlük, serbest, açıklayıcı vb. farklı türlerinin fen, sosyal, matematik gibi farklı disiplinlerde, öğrenme amaçlı olarak kullanılmasına neden olmuştur (Smagorinsky ve Mayer, 2014). Ancak Smagorinsky (1995) yazmanın öğrenmeye etkisinin olmadığı sınıfların olduğunu belirtmektedir.

Matematik programlarında yazarak öğrenmeden ilk olarak 1960'lı yılların sonlarında söz edilmiş, 1980'lerden sonra yazarak öğrenme iletişim ve öğrenme yöntemi olarak kullanılmaya başlanmıştır (Johnson ve Holcombe, 1993; Nagin ve National Writing Project, 2003). 1990'larda birçok ülke müfredatında (1995 y1lında İngiltere ve Galler'de, 1990 yllında Avustralya'da, 2002 yılında Güney Afrika'da), matematiksel sembolizmin yerine daha fazla sözlü ve yazılı dilin kullanımının teşvik edildiği belirtilmektedir (Ntenza, 2006). Ülkemizde ise 2005 y1lında uygulanamaya başlanan ve 2009, 2015 ve 2017 yıllarında revize edilen matematik dersi öğretim programında, geliştirilmesi hedeflenen temel becerilerden biri iletişim kurmadır. İletişim becerisinin geliştirilebilmesi içinse, matematik hakkında yazı yazmak önemli bir etkinlik olarak görülmektedir (Pugalee, 2001). Bu bağlamda, öğretim programlarında bir problemin çözümü ile ilgili ve bir kuralın ne anlama geldiğini açıklamak amacıyla öğrencilere yazılar yazdırılabileceği, ölçme ve değerlendirme amaçlı günlük yazdırılabileceğinden kısaca bahsedilmektedir (Milli Eğitim Bakanlığı [MEB], 2007). Ancak özellikle 2018'deki öğretim programında yazma uygulamalarının nasıl yapılacağına dair yeterli açıklamanın yapılmadığı görülmektedir.

Öğrenme amaçlı yazma, tüm öğrenim seviyelerinde öğretim programlarına dahil edilmesine rağmen, Günel (2009) yazma aktivitelerinin ülkemizde yeterince gündemde olmadığını ifade etmiştir. Ayrıca Günel (2009) eğitim bilimi araştırmalarının gündeminde olmayan öğrenme amaçlı yazma aktivitelerinin, bizler için keşfedilmeyi bekleyen yeni olgu olduğunu ve Türk eğitim sisteminde hedeflenen amaçlardan biri olan "bilimsel okuryazarlı̆̆ geliştirme" ve "anlamlı bilim öğrenmeyi" desteklemek için, öğrenme amaçlı yazma araştırmalarının ülkemiz araştırmacılarına yeni ufuklar açabileceğini belirtmiştir. 
Geleneksel sınıf ortamlarında öğrenciler matematik ile ilgili problemleri çözerken işlemleri kaydetmek amacıyla yazı yazmayı kullandığı ve bu süreçte çoğunlukla öğrencilerin düşüncelerinin farkında olmadığı, problemin çözümü üzerine düşünmediği ve ifadelerini zihinlerinde anlamlandıramadığı belirtilmektedir (Fluent, 2006). Bunun yerine tüm sınıfın etkin olarak katılabileceği konuşmaya göre daha bilinçli ve kasti olan analitik davranışı içeren yazma etkinliklerinin kullanılması gerektiği ifade edilmektedir (Jurdak ve Zein, 1998). Yazı ile birlikte öğrencinin kafasındaki sözcükler birer imaja (görüntüye) kavuştuğu için yazılı dilin, ses dilinden daha önemli ve etkili olduğu belirtilmektedir (Ergün ve Özsüer, 2006). Çünkü yazma öğrencilerin düşüncelerini somutlaştırmaktadır (Quinn ve Wilson, 1997). Öğrenciler yazma uygulamalarının kullanıldığı öğrenme ortamında daha aktif oldukları için öğrendiklerini anlamlandırabildikleri, kendi gelişimlerinin ve öğrenmelerinin farkında oldukları belirtilmektedir (Bolte, 1999). Yazma uygulamalarının faydalarının ve bunların öğretim üzerindeki etkilerinin fark edilmesi eğitimciler ve araştırmacıların bu konuya olan ilgilerini arttırmıştır (Ntenza, 2006; Seto ve Meel, 2006). Bugün pek çok alan eğitimi çalışmasında yazı yazma sadece bir dil becerisi olarak düşünülmemekte ve dil öğretiminin bir parçası olarak ele alınmamaktadır (Uğurel ve ark., 2009).

Matematik dersinin öğrenilmesi ve öğretilmesi zor olan derslerin başında geldiği belirtilmektedir (YetimKaraca ve Ada, 2018). Witzel ve Riccomini'ye (2007) göre akademik başarısı düşük olan öğrencilerin sayısının fazla oluşu, eğitim araştırmacılarını matematik başarısının arttırılmasını amaçlayan yeni öğretim stratejileri üzerinde çalışma yapmaları yönünde baskı unsuru oluşturmaktadır. Matematik programında yer alan yazma uygulamaları, öğrenciler arasındaki başarı farklılıklarını azaltma ve öğrenme ihtiyaçlarını tespit etmek için bir ögrenme stratejisi olarak görülebilir.

Öğrenme amaçlı yazma ile ilgili alanyazında olumlu görüş belirtilerek, matematik derslerinde kullanılması tavsiye edilmiştir (Burns, 2005; Jurdak ve Zein, 1998; Tekin-Aytaş ve Uğurel, 2016). Ancak araştırmacılar yazma etkinliklerini kullanma amacı olarak farklı görüşler ifade etmişlerdir. Bazı araştırmacılar öğrencilerin matematiğe algı ve tutumlarını düzenlemenin bir aracı olarak kullanmayı tavsiye etmiştir (Atasoy, 2005; Furner ve Duffy, 2002; Mason ve McFeetors, 2002; Nagin ve National Writing Project, 2003). Öğrencilerin düşüncelerini değerlendirmek için alternatif ölçme değerlendirme yöntemi olarak uygulayan çalışmalar vardır (Baxter, Woodward ve Olson, 2005; Burns, 2005; Miller, 1991; Nie, Yeo ve Lau, 2007). Bir kısım araştırmalar yeni kavram öğretimi için yazma etkinliklerinin araç olarak kullanmayı önermiştir (Brandenburg, 2002; Burns ve Silbey, 2001; Cooley, 2002; Fuqua, 1997; Marlow, 2006; McIntosh ve Draper, 2001; Williams, 2003). Öğrencilerin üstbilişsel becerilerini geliştirmek için (Tanner, 2012; Kartalc1, 2018) veya öğretmenlerin öğretim süreçleri hakkında bilgi sağlamak için (Atasoy, 2005; Seto ve Meel, 2006) kullanılabileceği de belirtilmiştir. Ayrıca öğretmenlerin kullandıkları yazma uygulamalarının çeşitleri, bu uygulamalarla ilgili olarak öğrenci ve öğretmen görüşleri üzerine çeşitli araştırmalar yapılmıştır (Demircioğlu, Argün ve Bulut, 2010; Guce, 2018; Öztürk, Öztürk ve Işık, 2016; Phillis, 2020). Ancak Shield ve Galbraith (1998), yazma uygulamaları üzerine ayrıntılı çalışmalar yapılmadığını belirtmiştir. Benzer olarak Herrick (2005), çalışmasında 55 tane yazma ile ilgili araştırmayı incelemiş ve yoğun yazma uygulamalarının yapıldığ 1 farklı akademik başarılara sahip öğrencilerin, bilişsel öğrenmelerindeki gelişimlerini inceleyen araştırmaların olmadığını belirtmiştir. Çalışmanın bu yöndeki eksikliği gidereceği düşünülmektedir.

Alanyazındaki çalışmalarda yazmanın öğrencilerin başarısına etkisini belirlemek için genellikle deneysel yöntemlerin tercih edildiği (Dur, 2010; Frenkel, 2004; Greer, 2010; Kasa, 2009; Pugalee, 2004; Y1lmaz, 2015) ve yazma etkinliklerinin çoğunlukla problem çözme sürecinde kullanıldığı (Özkan, 2019) tespit edilmiştir. Bu çalışmalarda, yazma uygulamalarının etkisi konusunda genel bir değerlendirme yapıldığı ve birbirine zit sonuçlar çıkmasını açıklamada yetersiz kaldığı görülmektedir. Ayrıca matematik eğitimi ortamlarının doğasındaki değişimlerden dolayı, matematikte yazmanın kullanılması ile ilgili yeni araştırmalara ihtiyaç vardır (DiBartolo, 2000). Graham, Kiuhara ve MacKay (2020) farklı tür yazma çeşitlerinin ve örneklem grubu olarak farklı seviyedeki öğrencilerin olduğu, 21 deneysel araştırmayı analiz edilerek öğrenme amaçlı yazma etkinliklerinin matematik üzerindeki etkisini belirlemiştir. Buna göre, öğrenme amaçlı yazma aktiviteleri matematik öğrenmeyi orta düzeyde etkilemektedir. Çalışmada ayrıca incelenen araştırmalardan sınırlı bilginin elde edildiğini, yazarak öğrenme ile ilgili ayrıntılı araştırmaların yapılması gerektiği ifade edilmiştir.

Son yıllarda ülkemizde matematik eğitiminde yazma etkinliklerinin kullanıldığ çalışmalara rastlanmaktadır. Özkan (2019) çalışmasında 6.sınıf öğrencilerinin yazdıkları günlüklerdeki matematiksel yapıların zamana göre nasıl değiştiğini araştırmıştır. Karma desen ile yürütülen çalışmanın verileri sadece alan ölçme konusunda 5 haftada toplam 13 ders saati süresince toplanmıştır. Araştırmada, yazma etkinliklerinin öğrencilerin alan ölçme konusunu kavramalarında etkili olduğu sonucuna ulaşılmıştır. Çalışmada yazma etkinliklerinin uzun süreli olarak planlanması önerilmektedir. Küçük (2019) ise Olasılık ve İstatistik öğrenme alanına ait 13 kazanım ile ilgili yazma etkinlikleri kullanarak 7. sınıf öğrencilerinin problem çözme becerisine, matematiğe yönelik tutum ve kaygılarına etkisini incelemeyi amaçlamıştır. Yarı deneysel desen ile gerçekleştirilen araştırmada veriler yedi haftada toplanmıştır. Çalışmanın amacı doğrultusunda kullanılan ölçeklerden elde edilen puanlar arasında deney grubu lehine istatistiksel olarak anlamlı bir fark olduğu görülmüş̧ür. Araştırmada yazma etkinlikleri farklı öğrenme alanlarında uygulanması ve daha derin bilgiler elde edilmesi için nitel araştırma deseninin kullanıldığı çalışmaların yapılması önerilmiştir. Akkuş ve Darendeli (2020) Türkiye'de 2005 ve 2020 yılları arasında, 
matematikte yazma üzerine yapılan toplam 35 araştırmayı incelemişlerdir. Araştırmalarında ülkemizde bu konuda yapılan çalışmaların oldukça az olduğunu, en fazla deneysel yöntemlerin kullanıldığını, sayılar dışındaki konularda yetersiz çalışma yapıldığını tespit etmişlerdir. Ayrıca ülkemizde öğrenme amaçlı yazma aktivitelerinin genellikle fen eğitimi alanında yapıldı̆̆ını, matematik eğitimi alanındaki çalışmaların yaygınlaştırılması gerektiğini belirtmişlerdir.

$\mathrm{Bu}$ çalışma, alanyazına göre çok daha uzun bir süre olan 14 hafta olarak, nitel desen kullanılarak tasarlanmıştır. Ayrıca altı farklı ünitede hazırlanan etkinlikler ile konu zenginliği sağlanmıştır. Araştırma, sınıflarında farklı yazma uygulama çeşitlerini ve yazılı iletişimi kullanarak matematik öğretimi yapmayı düşünen öğretmenlere bir öğretim yöntemi geliştirmeleri için katkı sağlayabilir ve etkinliklerini geliştirmede yol gösterebilir. Derslerinde yazma uygulamalarını nasıl kullanacaklarına dair bilgiler ve yeni fikirler sağlayabilir. Dolayısıyla çalışmanın daha fazla matematik öğretmeninin derslerinde yazarak öğrenme tekniğini kullanmalarına imkân sağlayacağı düşünülmektedir. Ayrıca çalışmanın sonuçlarına göre, farklı akademik başarıya sahip öğrencilerin matematik başarılarını arttırmaya yönelik çalışmalarda yazma uygulamalarının nasıl ve hangi gruplara uygulanabileceğine dair fikir verebilir.

Matematik öğretiminde yürütülen araştırmalarda farklı teknolojilerin kullanılmasına yönelik (özellikle bilgisayar teknolojisi) çalışmalara önem verilmekte ancak bunlar büyük maliyet gerektirmekte ve buna dayalı olarak maddi güçlüklerin ortaya çıkmasına neden olmaktadır (Bellamy, 2017). Ayrıca bu teknolojilerin kullanılmasında öğretmenlerin uzun bir hizmet içi eğitim seminerlerinden geçirilmesi gerekmektedir (Braine ve McNaught, 2007). Yazma uygulamaları ise çok az bir maliyet gerektiren (kâğıt masrafi), bir öğretmen rehberliğinde sinıflarda kolaylıkla uygulanabilir (Bellamy, 2017).

Yazı yazmanın bilişsel boyutu edinilen bilgilerin, duyumların ve görülenlerin sıraya konarak zihinsel işlemlerden geçirilmesini ve yorumlanmasını oluşturur (İpşiroğlu, 2006). Bilişsel gelişimin de farklı tanımları olmasına rağmen, bu tanımların ortak özelliği bilişsel gelişimin zihinsel faaliyet olduğudur (Losike-Sedimo, 2018). Öğrencilerin matematik konuları ile ilgili yaptıkları açıklamaların niteliğindeki gelişim, konu ile ilgili terminoloji kullanımındaki artış, yaptıkları hesaplamalar ve kullandıkları algoritmaların doğruluğundaki gelişme öğrencilerin bilişsel gelişmeleri ile doğrudan ilişkilidir (Baki, 2008). Bu araştırmanın amacı, yazma etkinliklerinin kullanıldığı matematik derslerinde akademik başarılarına göre çok düşük, düşük, orta, yüksek ve çok yüksek olarak gruplara ayrılmış ilköğretim 7. sınıf öğrencilerinin yazılı cevaplarını karşılaştırmak, bu etkinliklerin öğrencilerin matematikteki bilişsel öğrenmelerine olan katkısını incelemektir. Belirtilen amaç doğrultusunda çalışmanın problemi; yazma uygulamaları ile destekli matematik öğrenme ortamı farklı başarı düzeyine sahip 7. sınıf öğrencilerinin bilişsel öğrenmelerini nasıl etkilemektedir? olarak belirlenmiştir.

\subsection{Araştırmanın Teorik Çerçevesi}

1980'li yıllarda Sovyetler Birliği’nde, temelinde Vygotsky’nin fikirlerinin olduğu çok yaygın bir sosyalpedagojik hareket başlamıştır (Kerr, 1997). Vygotsky, bilginin sosyal çevre içindeki bireyler tarafindan paylaşıldığını ve kişinin bu sosyal çevre ile etkileşimi sonucunda bilgiyi oluşturduğunu kabul etmektedir. Böylece bireyin bilişsel gelişiminde önemli bir gelişme sağlanabileceği belirtilmektedir (Senemoğlu, 2000). Öğrencilerin kendi seviyesinde veya daha yüksek seviyedeki öğrencilerle çalışmalarının bilişsel düzeylerini bir üst seviyeye çıkarmaya yardımcı olacağı belirtilmektedir (Gray ve Feldman, 2004). Ayrıca Vygotsky’ye göre, yazılı dil, ses dilinden daha önemli ve etkilidir. Yazı yazma, üst düzeyde soyutlama gerektirdiğinden dolayı, sözlü konuşmadan her yönden farklıdır. Ayrıca yazma kimseye yönelik olmayan, içsel bir konuşmadır. Birey açıklama yaparken kendi kendine konuştuğu bir sürecin içerisine girer (Vygotsky, 1985).

Vygotsky’e (1985) göre öğrenenlerin iki farklı gelişme düzeyi vardır. Bunlardan biri olan mevcut gelişme düzeyinde, bireyin o anki zihinsel işleyişi ve belli konuları kendi başına öğrenebilme yeteneği yer almaktadır. Diğerinin ise potansiyel gelişme düzeyi olduğu belirtilmektedir. Bu düzey öğrenenin, öğretmen, anne-baba veya diğer akranlarının yardımı ile ulaşabileceği seviye olarak tanımlanmaktadır. Bu ikisi arasındaki bölge Vygotsky tarafından Yaklaşık Öğrenme Eşiği-YÖE (Zone of Proximal Development) olarak tanımlanmıştır (DeVries, 2000). Mevcut gelişme düzeyi ile potansiyel gelişme düzeyi arasında kalan bölge Şekil 1'de olduğu gibi gösterilebilir.

Potansiyel gelişme düzeyi

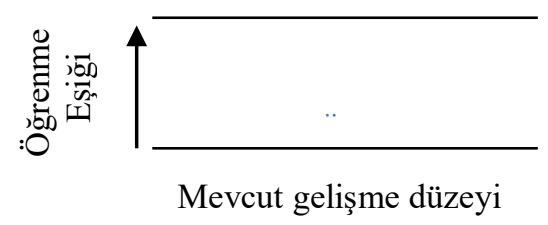

Şekil 1. Yaklaşık Öğrenme Eşiği 
Albert (2000) Vygosky'nin ortaya attığı YÖE kavramını genişleterek YÖU (yaklaşık öğrenme uygulamaları) kavramını sunmuştur. YÖE kavramında belirtilen, mevcut gelişim düzeyinden akran veya öğretmenin yardımlarıyla potansiyel gelişim düzeyine geçen öğrenciler, daha fazla analitik düşünme yeteneği gerektiren yazma etkinliğini kullanarak dışarıdan yardım alarak matematik kavram ve fikirleri kendi kendilerine düzenleyebilecekleri (self scalfolding) duruma geçerler. Kısacası yazma YÖE'den YÖU'ya bir köprü görevi görür (Albert, 2000). Albert (2000) YÖE'yi genişleterek Şekil 2'de görüldüğü gibi YÖU'ya geçişi şekillendirmiştir.

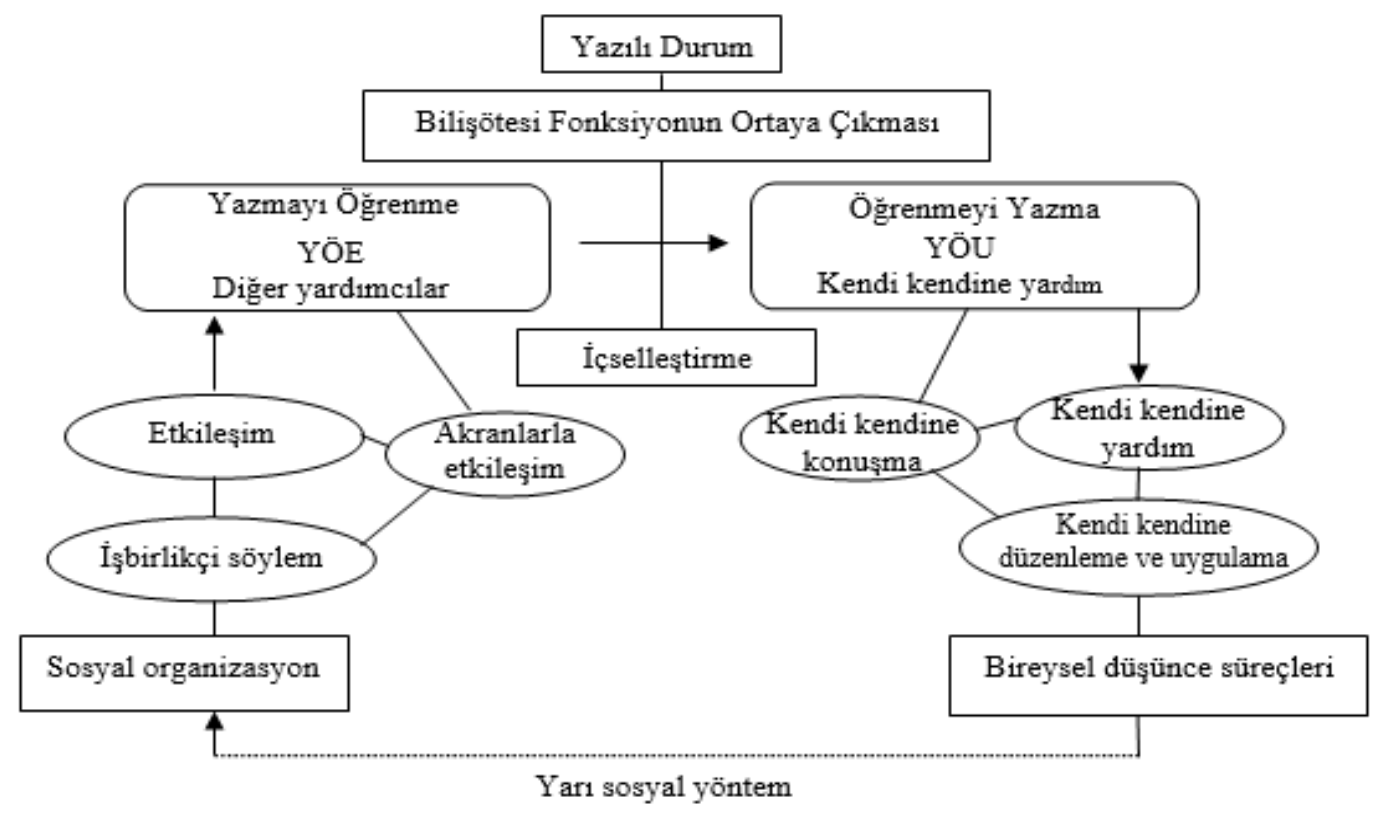

Şekil 2. YÖE ile YÖU arasındaki ilişki (Albert, 2000)

Öğrencilerin YÖU içinde matematiksel kavramlar ile ilgili düşüncelerini bağımsızca uygulayıp düzenleyebildikleri belirtilmektedir. YÖE'den geçerek YÖU'ya ulaşan öğrencilerin eleştirel düşüncelerinin gelişeceği ve daha derin bir matematik anlayışına sahip olacakları ifade edilmektedir (Albert, 2000). Buradaki temel düşünce sosyal ortamın dili, dilin yazmayı, yazmanında düşünceyi geliştirdiğidir.

\subsection{Matematikte Kullanılan Yazma Uygulamaları}

Matematik derslerinde öğrenme aracı olarak kullanılan yazma uygulamalarını sınıflandıran net bir çalışma yoktur. Birçok araştırma kullandıkları yazma uygulamalarını tanımlama yoluna gitmiştir (Phillis, 2020; Markert, 2019). Aslında bu tanımlamalar arasında da kesin çizgiler yoktur. Sipka (1992) matematik öğreniminde bir araç olarak yazmanın kullanımı ile ilgili olarak bir sınıflandırma geliştirmiştir. Ona göre tüm yazma uygulamaları resmi (formal) ve resmi olmayan (informal) olmak üzere iki kategoride toplanabilir. Resmi olmayan yazma içerik odaklıdır. Okuyucu yazarın düşünceleri ile ilgilidir. Resmi yazmada ise okuyucu yazmanın kalitesine ve içeriğine dikkat eder.

Britton, Burgess, Martin, Mcleod ve Rosen (1975) yazma aktivitelerini, iletişim amaçlı-resmi yazma (transactional writing), anlamlı yazma (expressive writing) ve şiirsel yazma (poetic writing) olarak üç kısma ayırmıştır. İletişim amaçlı-resmi yazma, ikna etmek, bilgi vermek ve öğretmek amaçlı yapılır. Okullarda en yaygın olarak yapılan yazma türüdür. Yazılı sınavlar ve resmi yazılar bu türe örnek olarak verilebilir. Öğrenciler bir soruya cevap yazarken veya tanım yaparken bunu kullanırlar. Ayrıca kitap bölümleri, araştırma makaleleri bu kısmın içerisinde yer alır. Anlamlı yazma ise kişinin içsel sesini ortaya çıkaran, resmi olmayan, plansız, kişisel bir yazma türüdür. Öğrenciler özel bir konu ile ilgili duygu ve düşüncelerini doğallık içerisinde yansitırlar. Günlükler ve serbest yazma en çok kullanılan şeklidir. Arkadaşa veya aileye mektup yazmak bu kategori içerisinde yer alır. Diğer bir yazma türü şiirsel yazmadır. Şiirsel yazma okullarda en az kullanılan yazma türüdür. Burada amaç yazmayı sanat gibi kullanmaktır. Yapı, şekil ve stil içerikten daha önemlidir. Matematik sınıflarında, verilen matematik kavramları ile şiir oluşturma, matematik özgeçmiş yazdırma veya "matematiksiz bir dünya" başlıklı bir kompozisyon yazdırma şeklinde yapılan bir yazma türüdür (Lynch, 2003). Hikayeler ve şarkılar yazma bu türe girer (Klishis, 2003). Bu kategorilere ek olarak Fulwiler (1984), dördüncü bir kategori olarak mekanik yazmayı eklemiştir. O, öğretmenin tahtaya yazdıklarını deftere kopyalama işini bu kategoriye dahil etmiştir. Bu yazma türünde fazla çaba harcamaya gerek yoktur. Yukarıda belirtilen kategoriler arasında kesin bir sınır yoktur. Örneğin King (1982), Britton'un yaptığı kategorilendirmede, anlamlı yazmanın alt kategorisinde yer alan günlük yazmanın, eğer öğretmenin yönlendirmesi ile yapılırsa, iletişim amaçl1-resmi yazma içerisinde yer alacağını belirtmiştir. 
Burns (2004) matematikte kullanılan yazma çeşitlerini dört kategoride toplar. Bunlar; günlükler, matematik problemi çözme, matematiksel fikirleri açıklama ve öğrenme süreçleri hakkında yazmaktır. Ishii (2003) matematik sınıflarında öğretme amaçlı yazma uygulaması olarak genellikle açıklayıcı yazma (expository writing) ve günlük yazma aktivitelerinin yapıldığını belirtmiştir. Araştırmacı, günlük yazmayı öğretmenin verdiği bir talimat-teşvik etme (prompt) çerçevesinde veya uygulama üzerine öğrencilerin düşünceleri olarak tanımlar. Açıklayıcı yazmayı ise doğası gereği bir soru veya problemi açıklamak olarak tanımlamıştır. Bu çalışmada kullanılan yazma uygulamalarını günlük ve açıklayıcı yazma olarak iki kategoriye ayırabiliriz.

Beasley ve Featherstone, (1995) öğrencilerin yazmaları için kullanılan talimatların, soruların ve senaryoların seçiminin çok önemli olduğunu, bunların öğrencilerin düşüncelerini ortaya çıkarabilecek konu ile ilgili öğrencilerin anlamalarını ölçebilecek nitelikte ve kapsamda olması gerektiğini belirtmiştir. Öğrencilerin bunlar üzerine düşünebilmeleri, çeşitli stratejiler seçebilmeleri ve uygulayabilmeleri, çözümlerinin mantıklılığını değerlendirebilmeleri ve süreç içerisindeki gelişimlerini izleyebilmeleri gerektiğini belirtmişlerdir (Silver ve Smith, 1996; Klishis, 2003). Colonnese, Amspaugh, LeMay, Evans ve Field (2018) ilköğretim seviyesinde matematiksel iletişim ve muhakeme için kullanılabilecek yazma çeşitlerini; keşfedici, açıklayıcı, tartışmacı ve yaratıcı olmak üzere dörde ayırmışlardır. Onlara göre keşfedici yazma; "kesirleri niçin kullanırız?" vb. şeklindeki sorulara ile öğrencilerin kesir kavramını keşfetmeleri ile ilgili açıklamalarını, açıklayıcı yazma; "Oyun alanının üçte birinin asfalt alanının üçte birinden daha büyük olduğunu nasıl bildiğinizi açıklayın." vb. talimatlara öğrencileri verdikleri yazılı cevapları içerir. Tartışmacı yazma; "İki farklı öğeyi karşılaştırırken, bir öğenin tamamı her zaman başka bir öğenin yarısından daha büyüktür. Katılıyor musunuz, katılmıyorsunuz ve neden? " vb. sorulara öğrencilerin, veri, iddia, gerekçe temel bileşenleri kullanarak yazı yazmasını, yaratıcı yazma ise keşfedici yazmada kullanılan benzer sorulara öğrencilerin “Ondalık olarak üçte biri 0.333333 ise... ve üçte ikisi $=0.666666 \ldots$, o zaman neden üçte üç 1'e eşit ve 0.999999 değil...? " şeklindeki cevaplardan oluşmaktadır.

Araştırmacılar matematikteki yazma uygulamalarında, öğrencilerin kolayca ve hızlıca çözüme ulaşabilecekleri sorular seçilmemesini, fikirleri üzerine düşünebilme imkânı sağlayan, çözüm süreçlerini anlamlandırabilecekleri, talimatlar ve sorular seçilmesini önermişlerdir (Roskin, 2010). Ayrıca bu talimatlar ve sorularda öğrenciler işlenen konunun dışındaki konular ile ilgili işaretler alması gerektiğini belirtmişlerdir (Klishis, 2003). Bundan dolayı yazma uygulamaları hazırlanırken alanyazında bahsedilen yukarıda belirtilen uyarılar dikkate alınmıştır.

\section{Yöntem}

Araştırmada, nitel araştırma yaklaşımı benimsenmiştir. Nitel araştırmalar bir konu üzerinde çalışma grubunun anlamalarını, tanımlamalarını, açıklamalarını ve bunların nasıl değiştiğini derinlemesine incelememize imkân sağlar (McMillan ve Schumacher, 2010).

\section{1. Çalışma Grubu}

Araştırmanın çalışma grubunu Trabzon iline bağlı bir ilçenin ilköğretim okulunda 7. sınıfında öğrenim gören toplam 37 öğrenci ( $23 \mathrm{kız}, 14$ erkek) oluşturmaktadır. Pilot çalışma grubunu ise aynı ilçede farklı bir ilköğretim okulunun 7. sınıfinda öğrenim gören 28 (15 kız, 13 erkek) öğrenci oluşturmaktadır. İlçe merkezinde bulunan okulların çevresinde sosyo-ekonomik düzey orta seviyededir. Öğrencilerin başarı seviyesi genellikle orta ve düşük olmakla birlikte, iyi seviyede de öğrenci bulunmaktadır.

\subsection{Araştırmanın Tasarlanması}

Çalışmanın tasarımında öncelikle 7. sınıf matematik öğretim programında 1. dönemde işlenecek üniteler incelenerek, uygulanacak materyal hazırlanmıştır. Şekil 3'de asıl çalışmaya kadar olan sürecin şematik açıklaması verilmiştir.

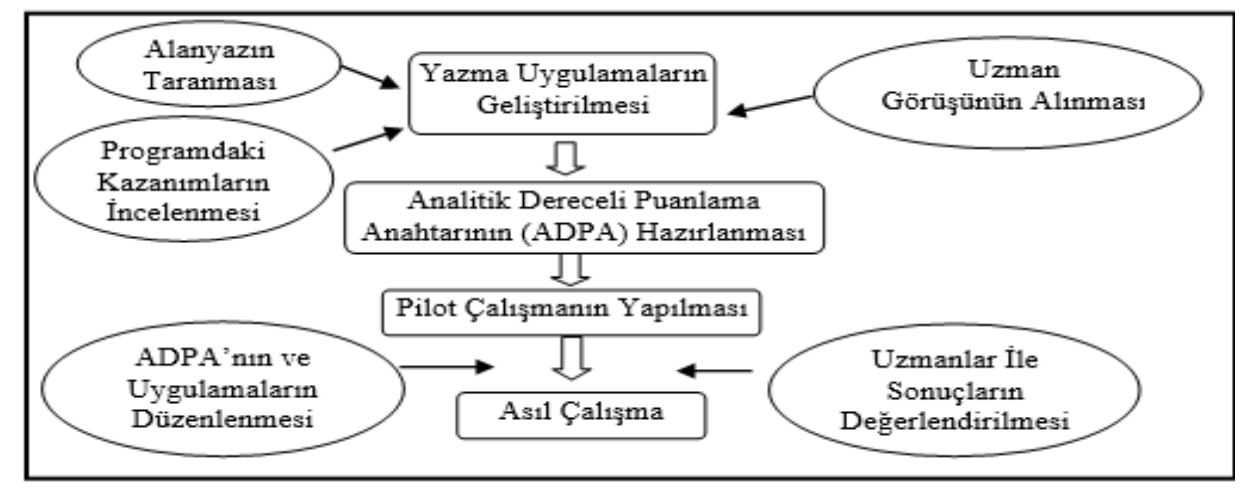

Şekil 3. Asıl çalışmaya kadar yapılan işlemlerin şeması 
Şekil 3'e göre, alanyazın taraması yapılarak ve öğretim programındaki kazanımlar incelenerek, geliştirilen yazma uygulamalarına yönelik uzman görüşleri alınmıştır. Ardından yazma uygulamalarının değerlendirilmesine yönelik ADPA hazırlanarak pilot çalışmaya geçilmiştir. Uygulamanın pilot çalışması ilköğretim 7. sınıfta 3 hafta boyunca yapılmıştır.

Pilot çalışma esas çalışmanın yapıldığı okuldan farklı bir ilköğretim okulunda 7. sınıfında toplam 28 öğrenci ile gerçekleştirilmiştir. Pilot çalışmada yer alan üç etkinlik, uzman ve öğretmen görüşü alınması, ders esnasında fazla zaman kaybına neden olması, öğrenci seviyesinin üzerinde olması ve aynı konuya ait başka etkinlikler olması nedenlerinden dolayı asıl çalışmadan çıkarılmıştır. Ayrıca pilot çalışmada, puanlama anahtarından öğrencilerin aldıkları puanların sınıfta okunuşu sırasında fazla zaman kaybı olduğu tespit edilerek, asıl çalışmada puanlar sınıftaki panoya asılarak ilan edilmiştir. Pilot çalışmada öğrencilerin puanları daha çok merak ettikleri tespit edildiğinden, asıl çalışmada uygulama kâğıtları öğrencilere dağıtılıp, dönütler ve etkinlik soruları cevaplandırıldıktan sonra puanlar panoya asılmıştır. Ayrıca uzman görüşü alınarak pilot çalışmada bazı sorular düzeltilmiştir. Örneğin, doğru ve açılar konusunun 2. etkinliğinde açının yeri değiştirilerek, sorunun daha fazla kazanımı içermesi amaçlanmıştır. Pilot çalışmada öğrencilere günlük yazdırılmıştır. Ancak bu günlüklerde öğrencilerin sınıfta geçen olayları anlattıkları belirlenmiştir. Dolayısıyla asıl çalışmada öğrenci günlüklerinin çalışmanın amacı doğrultusunda yazabilmeleri için yönlendirme yapılması kararlaştırılmıştır. Bu yönde günlüklerin alt başlıklara ayrılmasına karar verilmiştir (Ek-1).

Asıl çalışma ilköğretim 7. sınıfta 14 hafta boyunca uygulanmıştır. Araştırmada öncelikle öğretmene yazma uygulamasının sınıfta nasıl uygulanacağına hakkında bilgi verilmiştir. Literatürde öğrencileri yazmaya alıştırmanın en kolay yolu olarak matematik ile ilgili geçmiş yaşantılarını yazdırmanın olduğu belirtilmiştir (Burns, 1995). Bundan dolayı uygulama başında öğrencilere geçmişteki matematik yaşantılarını yazmaları ev ödevi olarak verilmiştir. Burada öğrencilerden geçmişte yaşadıkları matematik ile ilgili bütün his duygu, düşünce, iyi ve kötü anılarını, sevdikleri ve sevmedikleri matematik konularını matematiğin diğer derslerle bağlantıları hakkında ne düşündüklerini yazmaları istenmiştir. Ancak bu uygulama değerlendirmeye katılmamıştır. Daha sonra uygulamanın nasıl yapılacağı sınıfta anlatılmış ve örnek etkinlikler (Ek-1) öğrencilere dağıtılarak incelenmiştir.

Yazma uygulamaları, öğretmen dersini öğretim programına göre işledikten sonra genellikle her iki saatlik dersin son 10-20 dakikasında yapılmıştır. Uygulamadan sonra öğrencilerin yazdıkları kâğıtlar toplanıp dönütler verilmiştir. Verilen bu dönütler diğer dersin başında öğrencilere dağıtılarak incelemeleri sağlanmıştır. Daha sonra öğretmen öğrencilerde en sık rastladığı hataları düzeltmek amaciyla onlara farklı örnekler üzerinde açıklamalar yapmıştır. Öğrencilerin yazdıkları kâğıtlar, hazırlanan analitik dereceli puanlama anahtarına (ADPA) göre değerlendirilip puanlama yapılmıştır. Öğrencilerin ADPA'yı ve yapılan uygulamalardan seçilen bazı örnekleri görmeleri için sınıf panolarında matematik köşesi oluşturulmuştur. Bu köşede puanlama anahtarı dönem sonuna kadar asılı kalmıştır. Ayrıca bu panoya her uygulamadan sonra öğrencilerin ADPA'dan aldıkları puanlar asılmıştır. Yüksek puan alanlar sınıfta sesli olarak duyurulmuştur. Bu puanlara göre, bazen ders içerisinde öğrencilerin performansları hakkında konuşulmuştur.

Uygulama sonunda öğrenciler akademik başarı seviyelerine göre beş gruba (çok düşük, düşük, orta, yüksek ve çok yüksek) ayrılarak yazma uygulamalarına verdikleri cevaplar incelenmiştir.

\subsection{Veri Toplama Araçları}

Veri toplama aracı olarak yazma uygulamaları ve analitik dereceli puanlama anahtarı kullanılmıștır. Bu iki araç ile ilgili detaylı bilgi alt başlıklar altında sunulacaktır.

\subsubsection{Yazma Uygulamasının Geliştirilmesi}

Araştırmada toplam 26 yazma uygulaması yapılmıştır. Ayrıca öğrencilerin her birine ünite sonunda olmak üzere toplam 6 tane günlük tutturulmuştur. Bu uygulamalar ve günlükler alanyazına ve ilköğretim matematik programına dayalı olarak hazırlanmıştır. Ardından üç alan uzmanına ve bir ilköğretim matematik öğretmenine incelettirilmiştir.

$\mathrm{Bu}$ araştırmada, açıklayıcı ve günlük yazma uygulamaları kullanılarak, üç basamakta gerçekleşen bir plan dahilinde uygulamalar yapılmıştır. Tüm bu basamaklarda hazırlanan etkinliklerin, matematik programındaki kazanımları içermesine, günlük hayatla bağdaşmasına, öğrencinin daha ayrıntılı düşünmesini sağlayacak yapıda olmasına dikkat edilmeye çalışılmıştır. Birinci basamakta işlenen konuya ait kavrama vurgu yapan yazma uygulamaları, ikinci basamakta konunun içeriğine yönelik yazma uygulamaları, üçüncü basamakta ise ünite sonunda günlük yazma uygulamaları yapılmıştır. Bu basamaklar Şekil 4'de sunulmuştur. 


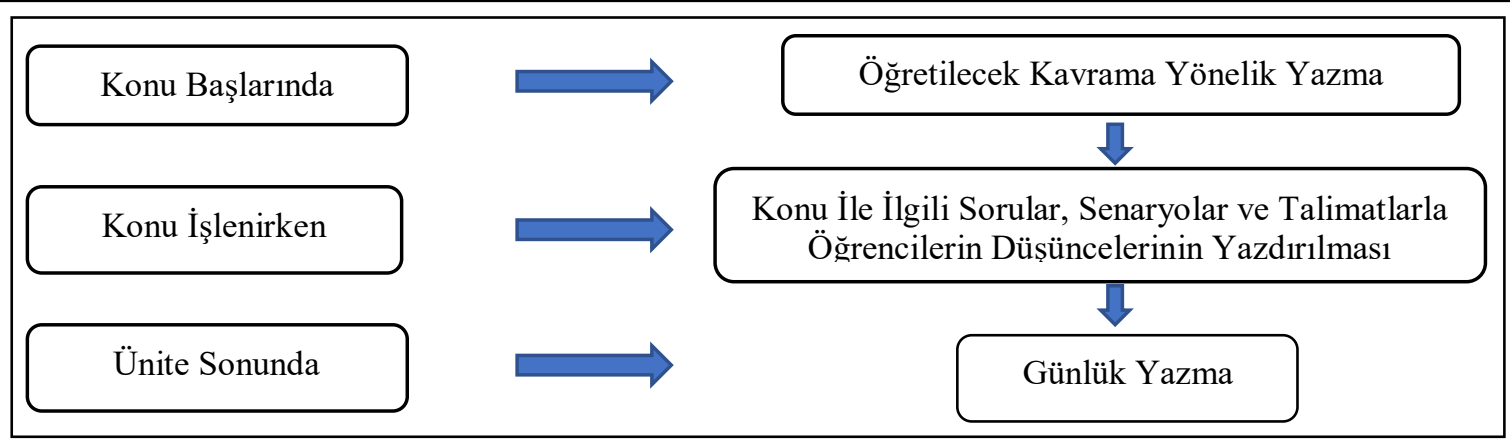

Şekil 4. Yazma uygulamalarının üç aşamalı planı

Öğrencilere düşünce süreçlerini ayrıntılı yazarken arkadaşından veya öğretmeninden yardım alarak, düşüncesini bütün strateji ve yöntemleri ile birlikte, hatta daha da ileriye giderek sonuca ulaştırmayan veya yanlıs sonuca ulaştıran "şöyle düşündüm sonuç çıkmadı" veya "yanlış çıktı" şeklindeki süreçleri bile yazmaları, 6. sınıftaki bir öğrenciye anlatıyormuş gibi açıklama yapmaları, düşüncelerini açıklamak için şekil çizebilecekleri, tablo yapabilecekleri ve örnekler verebilecekleri, noktalama ve dilbilgisi kuralları ile ilgili endişelenmemeleri, yanlışı silmemeleri sadece üzerini çizmeleri, teslim etmeden önce yazdıklarını okumaları söylenmiştir. Öğrencilerin kendilerinden alt sınıfta öğrenim gören öğrencilere anlatıyormuş gibi yazmaları, onların sahip oldukları bilgiyi anlamadan, tekrarlamalarını engellemekte ve kavramlar hakkında kendi anlayışlarını yapılandırmalarına izin vermektedir (Hohenshell, Hand ve Staker, 2004; Hand, Yang ve Bruxvoort, 2007).

Ünite sonlarında ise öğrencilerden, derslerde neler öğrendiklerini, neler yaptıklarını kendilerine zor gelen veya akıllarını karıştıran kısımları ve bu zorlukları aşmak için neler yapabileceklerini ayrıntısı ile günlük yazmaları istenmiştir. Aşağıda konu başlarında, konular işlenirken ve ünite sonlarında yapılan yazma uygulamalarından örnekler sunularak ayrıntılı bir şekilde açıklanmıştır.

Konu Başlarında:

Konu başlarında uygulanan etkinlik, anlatılan matematik kavramlarının öğrencilere verilen talimatlarla açıklayıcı yazma etkinliği yaptırılmasından oluşmaktadır. Bu basamağın amacı matematik kavramlarına vurgu yapmaktır.

Örneğin;

a.Kendinizi rasyonel sayı olarak düşünün. "Ben bir rasyonel sayıyım" başlı̆̆ altında kendinizi ve akrabalarınız (diğer rasyonel sayılar ve sayı kümeleri ) ile olan ilişkilerinizi yazarak anlatınız.

Konu İşlenirken:

Konu anlatımı ilerledikçe yapılan uygulama, açıklayıcı yazma etkinliğidir. Burada anlatılan matematik kavramı ile ilgili talimatlara, senaryolara ve açık uçlu sorulara verdikleri cevaplardan oluşmaktadır.

Örneğin;

a.Ahmet yandaki şekilde verilenlere göre, $d$ ve e doğrularının paralel olduğunu, Ayşe ise paralel olmadığını söylüyor. Sizce kim haklıdır? Cevabınızı nedenleri ile açıklayınız.

b.* Eşitliğin her iki yanına 5 eklenir.

* Eşitliğin her iki yanı 2 ile çarpılır.

Bir denklemin çözümü için yukarıdaki işlemleri sırasıyla uygulayan bir öğrenci denklemin çözüm kümesini 12 olarak bulmuştur. Buna göre bu denklem nasıl bulunabilir? Açıklayınız.

Ünite Sonunda:

Ünite sonlarında (genellikle iki veya üç haftada bir) günlük yazdırma etkinliğidir. Bu etkinlik evde yaptırılmıştır. Öğrencilerden bir sonraki matematik dersine bunları getirmeleri istenmiştir. Bu günlükler çalışmanın amacı doğrultusunda ve Lefler'den (2006) yararlanarak geliştirilmiştir. Günlük yazma etkinliği öğrencilere aşağıdaki 4 alt başlıktan oluşan talimatlar verilerek yaptırılmıştır.

a.Sınıfta olmayan bir arkadaşınıza işlediğimiz konuyu özetleyen bir mektup yazınız. Öğrencilere "sınıfta olmayan bir arkadaşınıza (derste başarılı olmayan) konuyu açıklayınız. Arkadaşınız konuyu bilmiyor ve tamamen sizin anlatacaklarınıza güveniyor. Dolayısıyla konu ile ilgili her ayrıntıyı belirterek, örnekler vererek yazınız." şeklinde uyarılar yapılarak buna göre açıklama yapmaları istenmiştir.

b.Derslerde İşlenen kavramları sıralayarak, aralarındaki ilişkiyi belirleyiniz.

c.Konu ile ilgili karşılaştığınız güçlük veya sorunları belirtiniz.

d.Daha önce bilmeyip, konular işlendikten sonra öğrendiğiniz en önemli bilgi nedir?

Ayrıca öğrenciler sınıf içerisinde yaşanan sıradan, ders dışı (öğretmen Ali’yi tahtaya kaldırdı vs.) olayları günlüklerinde anlatmamaları konusunda özellikle uyarılmışlardır. Uygulama sırasında öğrencilerin kendi 
aralarında ve öğretmeni ile tartışmalarına izin verilmiş, ancak kesinlikle birbirlerine bakmadan yazmaları istenmiştir. Jurdak ve Zein (1998) yazma uygulamasında öğretmenin hızlı ve kısa dönütler vermesinin, günlükler dışındaki tüm uygulamaların puanlanması gerektiğini ifade etmiştir. Bu doğrultuda yazma uygulamalarına öğretmen öğrencileri motive edecek, hatalarını görmelerini sağlayacak kısa dönütler yazmıştır.

Yazma uygulamalarının sayısı öğrenme alanı, alt öğrenme alanı, kazanım ve ders saati süresi dikkate alınarak düzenlenmiştir. Alt öğrenme alanları ve uygulama sayıları; Doğrular, açılar ve açıları ölçme, 2 uygulama; Tam sayılarla işlemler, 10 uygulama; Rasyonel sayılar, 6 uygulama; Cebirsel İfadeler, 2 uygulama; Denklemler, 3 uygulama; Oran ve orantı, 3 uygulama olmak üzere toplam 26 yazma uygulaması yapılmıştır. Bunlar çalışmadaki uygulama zamanına bağlı olarak çalışmanın başında, ortasında ve sonunda olmak üzere üç kısma ayrılmıştır. 1.-9. uygulama çalışmanın başında yapılan uygulamalar olarak, 10.-18. uygulamalar çalışmanın ortasında yapılan uygulama olarak, 19.-26. uygulamalar ise çalı̧̧manın sonunda yapılan uygulamalar olarak belirlenmiş̧ir. Araştırma toplam 56 ders saatlik bir süreyi kapsamaktadır. Ancak bu ders saatlerinin tamamında yazma uygulaması yapılmamıştır. Uygulamalar genellikle 2 ders saatinin son 10-20 dakikası içerisinde gerçekleştirilmiştir. Yazma uygulamaları dışında her öğrenciye ünite sonlarında toplam 6 tane günlük yazdırılmıştır.

\subsubsection{Analitik Dereceli Puanlama Anahtarının (ADPA) Hazırlanması}

DiBartolo (2000) yazma uygulamalarını değerlendirmek için dereceli puanlama araçlarının etkili ve verimli araçlar olduğunu belirtmiştir. Analitik dereceli puanlama anahtarı (ADPA), bütüncül ve karakteristik dereceli puanlama anahtarından farklı olarak performans parçalarını veya ürünü bölümlere ayırmak ve her beceriyi bağımsız olarak değerlendirmek, sonrasında her bir bölümden alınan puanların toplamının veya ortalama puanın bulunmasını gerektirir. Dolayısıyla çalışmanın ya da ürünün farklı boyutlarına farklı notlar vermek amacıyla oluşturulur.

Yazma uygulamalarını değerlendirmek için hazır, uyarlanmış veya araştırmacının kendisinin hazırlayacağı puanlama anahtarı kullanılabilmesine rağmen, araştırmanın güvenirliğini arttırmak için uyarlanmış bir puanlama anahtarı kullanılmıştır. Lim ve Pugalee'den (2006a; 2006b) uyarlanan taslak puanlama anahtarının, araştırmadan elde edilen yazılı verilerin ön incelemesi sonucu uygun olduğuna karar verilmiş̧ir. ADPA, üç alan uzmanına ve bir ilköğretim matematik öğretmenine inceletilerek, çalışmanın doğasına uygun olduğu kanaatine varılmıştır. Böylece aşağıda boyutları verilen puanlama anahtarı asıl çalışmada kullanılmıştır.

ADPA üç kategoriden oluşmaktadır. Bunlar; a)Açıklamaların özelliği, b)Matematiksel dili kullanma, c)Matematiksel yapı ve hesaplamalardır. Bu başlıklar altında öğrencilerin yazdıkları ADPA'ya göre puanlandırılmıştır.

\subsection{Verilerin Analizi}

Veriler analiz edilmeden önce öğrencilerin akademik başarı seviyelerine nasıl ayrıldığı açıklanmıştır. Ardından yazma uygulamalarının çalışmanın başında, ortasında ve sonunda olmak üzere üç gruba ayrıldığı belirtilmiştir. Daha sonra akademik başarı seviyelerine ayrılan öğrencilerin uygulamaya verdikleri yazılı cevapların analizinin nasıl yapıldı̆̆ açıklanmıştır.

Araştırmanın temel problemi, yazma uygulamalarının akademik başarı seviyeleri farklı olan öğrencilerin bilişsel, duyuşsal gelişiminin belirlenmesi ve bu öğrencilerin yazma uygulamasına verdikleri cevaplar arasındaki ilişkinin ortaya çıkarılması olduğundan, öğrencilerin akademik başarı seviyesine ayrılması gerekmiştir. Bunun için aşağıda belirtilen yol izlenmiştir.

a) Öncelikle öğrencilerin 6. sınıfta 1. ve 2. dönem yazılı sınavlarının (toplam 6 sınav) ortalaması alınmıştır. Burada öğrencilerin performans değerlendirme notları hesaplamaya katılmamıştır.

b)Akademik başarı seviyesi orta olan 24 öğrenciden bazılarının yazılı sınavlarının ortalamaları birbirine çok yakın olması dolayısıyla uygulama öğretmeninin görüşü doğrultusunda (öğretmen geçmiş bir yıl boyunca öğrencilerin dersine girmiştir. Dolayısıyla öğrencilerin seviyesi ile ilgili bilgi sahibidir.) bu başarı seviyesindeki öğrenciler kendi aralarında akademik başarı seviyesi düşük, orta ve yüksek olmak üzere üç gruba ayrılmışlardır.

Tablo 1. Akademik başarı sevilerine göre ayrılmış öğrencilerin sayıları

\begin{tabular}{cccccc}
\hline & Ortalama 0-25 & & Ortalama 30-68 & Ortalama75-100 \\
\hline \multirow{2}{*}{ Seviye } & Çok Düsük & Düşük & Orta & Yüksek & Çok Yüksek \\
& (E seviyesi) & (D seviyesi) & (C seviyesi) & (B seviyesi) & (A seviyesi) \\
Öğr. sayıs1 & 10 & 9 & 10 & 5 & 3 \\
\hline
\end{tabular}

Tablo 1'e göre, 6. Sinıfta yazılı puanlarının ortalaması 0-25 arasında olan 10 öğrenci "çok düşük" (E seviyesi), yazılı puanlarının ortalaması 30-68 arasında olan 24 öğrenci öğretmen görüşü alınarak başarı seviyelerine ayrılmış sonuçta 9 öğrenci "düşük” (D seviyesi), 10 öğrenci "orta” (C seviyesi), 5 öğrenci "yüksek" 
(B seviyesi) olarak isimlendirilmiştir. Ayrıca yazılı puanlarının ortalaması 75-100 arasında olan 3 öğrenci “çok yüksek" (A seviyesi), olarak isimlendirilerek akademik başarı seviye grupları oluşturulmuştur.

Akademik başarı seviyesine ayrılan öğrencilerin yazma uygulamalarına verdikleri cevaplara içerik analizi yapılmıştır. Öğrencilerin yazdıkları analiz edilmeden genel bir çerçeve oluşturmak için ADPA kullanılarak üç tema belirlenmiştir. Veriler kodlanarak bu temalar ile ilişkilendirilmiştir. Öncelikle başarı seviyelerine ayrılan ögrencilerin yazma uygulamasına verdikleri cevapların hepsi grup olarak ayrı ayrı yüzeysel olarak incelenerek notlar alınmış, daha sonra tekrar başa dönülerek ayrıntılı olarak inceleme yapılmıştır. Ortaya çıkan kodlar arasındaki benzerlikler ve farklılıklar belirlenerek birbiriyle ilişkili olanlar bir araya getirilerek temalarla ilişkilendirilmiştir. Tablo 2'de tema ve ilgili kodların son hali sunulmuştur.

Tablo 2. Temalar ve kodlar

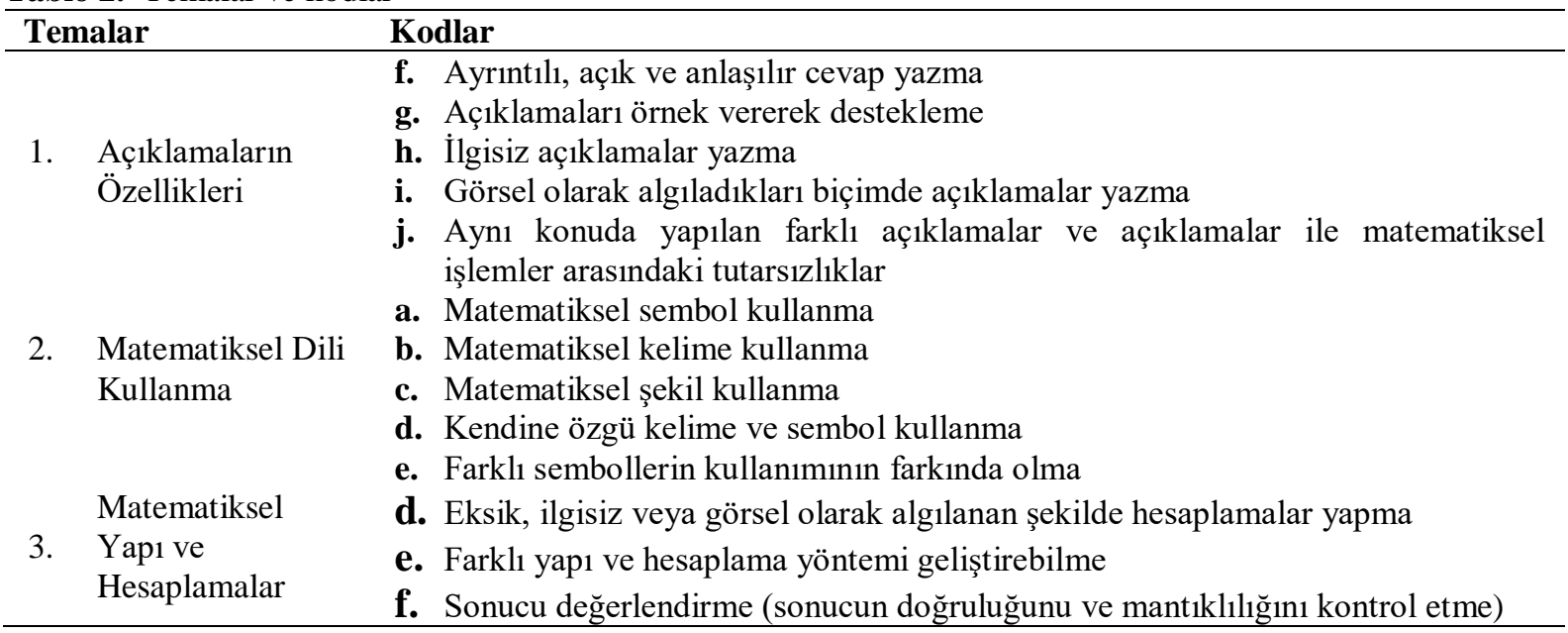

Tablo 2'ye göre, araştırmanın bulguları üç tema altında toplanmıştır. Bu temalar açıklamaların özellikleri, matematiksel dil, matematiksel yapı ve hesaplamalardır. Bu temalar altında ilgili kodlar yer almıştır. Son aşamada ise araştırmacı topladığı verilere anlam kazandırmak, bulgular arasındaki ilişkileri açıklamak, nedensonuç ilişkisi kurmak, bulgulardan birtakım sonuçlar çıkarmak ve elde edilen sonuçların önemini belirtmek için açıklamalar yapmıştır (Yıldırım ve Şimşek, 2005).

Akademik başarı seviyelerine göre ayrılan öğrencilerin, analitik dereceli puanlama ölçeğinden aldığı puanlar, ölçekte yer alan üç temaya göre (matematiksel açıklamalar, matematiksel dil kullanımı ve matematiksel yapı hesaplamalar) sınıflanmıştır. Burada öğrencilerin yazma uygulamalarına verdikleri cevapların önceden puanlanması sonra başarı seviyelerine ayrılması araştırmanın güvenirliğini arttıran bir etmendir. Sınıflamanın ardından, her temadaki akademik başarı seviyelerine göre grupların kendi içerisinde gelişim olup olmadığına bakılmıştır. Bu amaçla, çalışmanın başında, ortasında ve sonunda olmak üzere üç kısma ayrılan uygulamalardan, öğrencilerin ADPA’dan aldıkları puanların ortalamaları hesaplanarak yorumlanmıştır.

ADPA'nın puanlamasını, araştırmacı ve uygulama öğretmeni birbirinden bağımsız olarak yapmıştır. Puanlar arasındaki tutarlılığa bakmak için yapılan analizde Pearson korelasyon katsayısı 0.92 olarak hesaplanmıştır. Elde edilen bu katsayı, puanlayıcılar arası yüksek düzeyde ilişkili olduğunu gösterdiği için yeterli görülmüştür (Büyüköztürk, 2005). Çalışmaya katılan öğrenciler Ö1, Ö2,.., Ö37 şeklinde kodlanmıştır. Günlüklerin dışındaki tüm uygulamalar bu anahtar kullanılarak puanlanmıştır.

\section{Bulgular}

Çalışmada uygulanan yazma etkinliklerindeki yazılı cevaplar incelenerek, öğrencilerin bilişsel gelişimleri ile ilgili üç farklı tema oluşturulmuştur. Temalar, kodlarla ilişkilendirilerek tablolar oluşturulmuştur. Tablolarda seviye sütunundaki A3, B5, C10 vb. ifadeler öğrenci sayısını da belirtmektedir. Örneğin, A3, A seviyesinde 3 öğrenci bulunduğunu göstermektedir. Ardından öğrenci uygulamalarından örnekler verilmiştir. Ayrıca her temanın sonunda, öğrencilerin başarı seviyelerine göre ADPA’nın ilgili kısmından aldıkları puanların ortalamaları sunulmuştur.

\section{1. "Açıklamaların Özellikleri” Temasından Elde Edilen Bulgular}

Akademik başarılarına göre ayrılmış öğrencilerin uygulamalara verdiği yazılı cevaplar, açıklamaların özellikleri teması altında incelenerek oluşturulan kodlar Tablo 3'de sunulmuştur. Bu kodlara hangi öğrencilerin kâğıtlarından ulaşıldığı, çalışmanın hangi aşamasında yapılan uygulamalarda karşılaşıldığı tabloda belirtilmiştir. 
Tablo 3. Açıklamaların özellikleri temasına göre oluşturulan kodlarda yer alan öğrenciler

\begin{tabular}{|c|c|c|}
\hline$\stackrel{.}{.}$ & $\begin{array}{c}\text { Ayrıntılı, } \\
\text { açık ve } \\
\text { anlaşılır }\end{array}$ & $\begin{array}{c}\text { Açıklamaları } \\
\text { örnek } \\
\text { vererek } \\
\text { destekleme }\end{array}$ \\
\hline
\end{tabular}

İlgisiz
açıklamalar
yazma

Görsel olarak
algıladıkları
biçimde
açılamalar
yazma

Aynı konuda yapılan

farklı açıklamalar ve açıklamalar ile matematiksel işlemler arasındaki tutarsızlıklar

\begin{tabular}{|c|c|c|}
\hline & $\mathrm{A}_{3}$ & Ö1, Ö2, Ö3 \\
\hline$\Xi$ & $\mathrm{B}_{5}$ & Ö4 \\
\hline 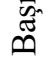 & $\mathrm{C}_{10}$ & -------- \\
\hline 志 & $\mathrm{D}_{9}$ & --- \\
\hline $\bar{\pi}$ & $\mathrm{E}_{10}$ & -------- \\
\hline
\end{tabular}

Ö1,Ö2, Ö3
Ö5, Ö6
Ö8, Ö9,Ö10
Ö15, Ö16,
Ö17
-----

-------
Ö8, Ö11,
Ö12

Ö18,Ö19 Ö14, Ö1

Ö20, Ö16, Ö24, Ö25, Ö26, Ö27

\begin{tabular}{|c|c|c|}
\hline & $\mathrm{A}_{3}$ & Ö1, Ö2, Ö3 \\
\hline & $\mathrm{B}_{5}$ & Ö33 Ö7, Ö5, \\
\hline & & Ö4, Ö6 \\
\hline 㶓 & $\mathrm{C}_{10}$ & $\begin{array}{l}\text { Ö14, Ö8, } \\
\text { Ö31, Ö10 }\end{array}$ \\
\hline & $\mathrm{D}_{9}$ & Ö18, Ö17 \\
\hline & $\mathrm{E}_{10}$ & -- \\
\hline
\end{tabular}

Ö1, Ö2, Ö3

Ö6, Ö33, Ö4

Ö31, Ö8 Ö11,

Ö14, Ö12 Ö16

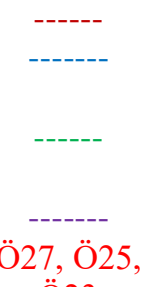

Ö26, Ö27, Ö28, Ö23, Ö29

Ö7
Ö10, Ö13,
Ö14, Ö11

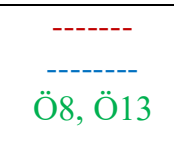

Ö22, Ö17, Ö23

Ö27, Ö28, Ö30, Ö29

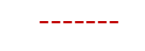

\section{Ö23}

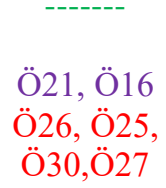
$\mathrm{A}_{3} \quad \mathrm{O} 1, \mathrm{O} 2, \mathrm{O} 3$
$\mathrm{B}_{5}$ Ö33,Ö4,Ö6, Ö5
㱏 $\mathrm{C}_{10}$ Ö11,Ö31,
Ö14,Ö8, Ö10
Ö22, Ö18,
Ö16,Ö15
$\mathrm{E}_{10}$

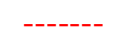

Ö1, Ö3, Ö2

Ö7, Ö6, Ö4, Ö33

Ö14, Ö8, Ö31, Ö10,Ö31

Ö15, Ö16

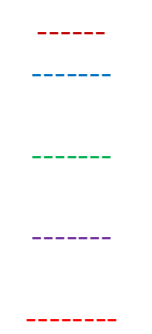

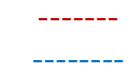

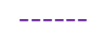

Ö16

Ö29,Ö25 Ö32,

Ö29, Ö25, Ö27, Ö23, Ö24, Ö27 Ö32,Ö37

Tablo 3'e göre, ayrıntılı, açık ve anlaşılır cevap yazma kodunda C ve B seviyesindeki öğrencilerin cevaplarının anlaşılırlığının belirgin olarak arttığı, D seviyesindeki bazı öğrencilerde de gelişim olduğu belirtilebilir. İlgisiz açıklamalar yapma koduna göre, E seviyesindeki öğrencilerin çalışmanın başında ve ortasında ilgisiz açıklamalar yaptıkları ancak daha sonra yapmadıkları, D ve C seviyesindeki öğrencilerin çalışmanın başında bazı uygulamalarda ilgisiz açıklamalar yapmalarına rağmen çalışmanın orta ve sonlarında yapılan uygulamalarda ilgisiz açıklamalar yapmadıkları belirlenmiştir. Geriye kalan B ve A seviyesindeki öğrencilerin ise çalışmada hiçbir uygulamaya ilgisiz açıklama yazmadıkları belirlenmiştir. Görsel olarak algılanan biçimde cevap yazma kodunda E seviyesindeki öğrencilerin genelinde bu duruma örnek olan cevaplara rastlanmıştır. D seviyedeki öğrencilerden bazıları çalışmanın başlarındaki ve ortalarındaki uygulamalara görsel olarak algıladıkları şekilde cevap yazmışlar, C ve B seviyesindeki öğrencilerden sadece birkaçı çalışmanın başında yapılan bazı uygulamalara bu şekilde cevap yazmışlardır. A seviyesindeki öğrencilerde bu duruma rastlanmamıştır.

Aynı konuda yapılan farklı açıklamalar ve açıklamalar ile matematiksel işlemler arasındaki tutarsızlıklar kodunda E seviyedeki öğrencilerde çalışmanın genelinde bu duruma rastlanmıştır. D seviyesindeki öğrencilerde bu duruma rastlanan öğrenci sayısı üç olmasına rağmen çalışmanın sonlarında bire gerilemiştir. C seviyesinde iki öğrencide de çalışmanın başlarında benzer durumlar olmasına rağmen çalışmanın devamında bu tür duruma rastlanmamıştır. Diğer akademik başarı seviyesindeki öğrenciler için ise çalışmanın hiçbir aşamasında bu tür duruma örnek olacak bulguya rastlanmamıştır.

Açıklamalarını örnek vererek destekleme koduna göre, E seviyesindeki öğrenciler yaptıkları açıklamalara hiç örnek yazmadıkları tespit edilmiştir. Diğer başarı seviyelerindeki özellikle akademik başarı seviyesi C, B ve A olan öğrencilerin uygulamalarda açıklama yazarken örnek verdikleri tespit edilmiştir. Tablo 4'de öğrencilerin uygulamalara verdikleri yazılı cevaplardan açıklamaların özellikleri teması ile ilgili örnek alıntılar sunulmuştur. 
Tablo 4. Açıklamaların özellikleri temasına göre öğrenci cevaplarından örnekler

$\sum_{0}$ Uy. $\quad$ Örnek Cevaplar

A 2 Şekildeki dolap paralel doğrulardır. Çünkü dolabın iç kısmındaki tahtalar birbirinin altına dizilidir ve karşılıklı olarak duruyor. Bu nedenle bu paralel doğrudur ve ayrıca iç tahtaları uzattığımızda hiçbir zaman kesişmezler. Buda paralel doğruların özelliğidir (Ö2)

6 Evet vardır. Çünkü eksi sayılar 10’la çarpıldığında küçülürler. Çünkü normal çarpma işlemi yapıldığında sonuç büyük ama çarpanların ikisinin de işareti farklı ise sonuç negatif olur yani küçülür. Aşağldaki işlemler buna örnektir. $(-30) \cdot(+10)=(-30) \quad(-30)<(-3) \quad(-5) \cdot(+10)=(-50) \quad(-$ 50) $<(-5) \quad(\ddot{O} 3)$

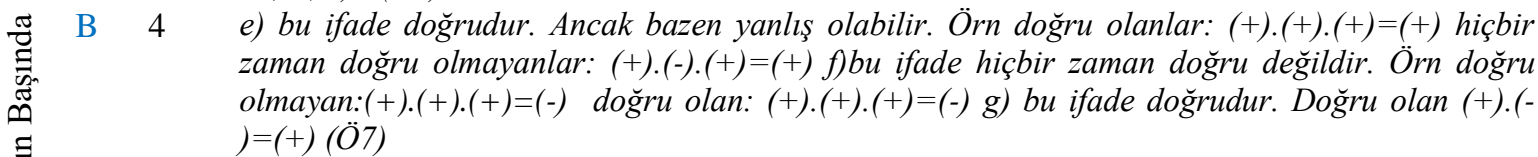

2 Bence Ahmet doğru söylüyor. Çünkü şekilde de görüldüğ̈̈ gibi d ve e doğruları birbirine paralel olarak çizilmiştir ve bu doğrular birbirine paraleldir. Bence Ahmet çok doğru bir düşünce içindedir. Benim düşüncem bu e doğrusunun açısı d doğrusunun açısına eşittir (Ö7)

C $2 \ldots d$ açısındaki $128^{\circ}$ ters açısı olan diğer bir açısı $128^{\circ}$ dir. Diğer e doğrusundaki 128 açısının ise ters açısı... e doğrusundaki açısının dış ters açısı olan d doğrusundaki 52 açısıdır (Ö8)

$1 \quad$ Şekillerdeki a şeklinde verilen merdiven dikdörtgen olarak verilmiş ve karşılıklı iki kenarı eşittir. Her açısı $90^{\circ}$ dir. B şeklinde verilen üçgen ve yamuk verilmiştir. C şeklinde bulunan da bir rafları paralelkenar olarak verilmiştir (Ö8)

D 2 Bir paralel doğru $180^{\circ}$ 'dir. $52^{\circ}$ ve $128^{\circ}$ çıklyor. Dik doğru ise $90^{\circ}$ dir (Ö21)

E 2 ...açıları aynı olduğu için cevap paralelkenar buldum (Ö24)

A 11 Laboratuarın sicaklığl $14 c^{0}$ den $-22 c^{0}$ düşmüşse önce biz 9 saatte ne kadar düşü̈̆ünü bulmalıyız.(+14)-(-22) şeklini yaparak bulacağız. $(+14)+(+22)=36$ c 9 saatte düşmüştür. 1 saatte düşeni bulmalıyı ki 5 saati bulalım. Öyleyse; $(+36):(+9)=+4$ bir saatte düşmüş̧ür. Biz 5 saatin sonunda ne kadar olduğunu bulacağız. (+4).(+5)=20 dir. Şimdi sicaklı̆̆ bulalım. Oda slcaklı̆ $\breve{g}_{l} 14 c^{0}$ ise $(+14)-(+20)=(+14)+(-20)=-6$ olarak buluruz $(\ddot{O} 2)$

B 17 Öncelikle bu işlemleri açıklayarak başlarsak; ilk önce Ali bu işlemi bileşik kesre çevirmeden payları eşitlemiş ve daha sonra işlemi yapmıştır. Ayşe ise...daha sonra paylarını eşitleyerek çıkarma işlemini yapmıştır. Ahmet ise ilk önce paydalarını eşitlemiştir...şimdi bana göre doğru işlemi yapan Ayşe’dir. Çünkü Ayşe, yukarıda da belirttiğim gibi önce işlemi bileşik kesre çevirmiş...işlemi örnek olarak gösterecek olursak; (yani bana göre)...(Ö7)

C 14 2/3 sayısı 4/6 sayısının yarısıdır. Bu şekilde 4/6 sayısı 2/3'ün iki katıdır. Bir rasyonel sayıda eşitlik olabilmesi için pay ve paydasının aynı sayı ile çarpılması gerekir (Ö8)

D $185+12=17$ Trabzonspor, $1+6=7$ Beşiktaş... 5 kişide takım tutmuyor (Ö16)

A 19 Bence eşit değildir. $\left(2 x^{3}\right)$ parantez içindedir. Bu durumda değişiklik olur. Bunu açarsak; 2'i 3 kere çarpmak demektir. Yani; $2 x .2 x .2 x$. olur. Bu işlemlerin sonucu $(2 x)^{3}=8 x^{3}$ dur. Bu durunda $8 x^{3} \neq 2 x^{3}$ olur $(\ddot{O} 2)$

23 Kitabın kısa kenarını silgi ile ölçerken uç uca 3 kez eklendiği zaman $3 x$ olur. Yani $=x+x+x+6$ olur. $6 \mathrm{~cm}$ geride kalır. $5 \mathrm{kez}$ eklendiğinde yani $=x+x+x+x+x-2$ olur. $2 \mathrm{~cm}$ ise fazla gelir... $x+x+x+6=3 x+6 \quad x+x+x+x+x-2=5 x-2$ buradan $3 x+6=5 x-2$ denklemi ortaya çıkar. (Ö7)

B $22 x+9=30$ şimdi yukarıda verdiğim işlemi anlatacağım. Şimdi bir şehirde iki kasaba var. 1. kasabada x virüsü var diğer kasabada ise virüs yok 1. Kasabadaki sayllar diğer kasabaya geçmek istiyorlar...karşıya geçerken jandarmaya yakalanıyor. Jandarma nereye gittiğini soruyor. +9'da cevap veriyor. Daha sonra jandarma +9'a diyor ki karşlya geçmek istiyorsan işaretini değiştireceksin. +9 kabul ediyor ve karşıya -9 olarak geçiyor. Şimdi işlemi yaparsak; $x+9=30$ $x=30-9 \quad C \zeta=\{21\}$ olur. -9 sayısı da virüsten kurtulmuş olur $(O ̈ 7)$

24 Iki çokluktan biri artıyorsa ve diğeri de aynı oranda artıyorsa veya biri azalırken diğeri de aynı oranda... buna doğru orantı denir. Günlük hayattan örnek verirsek: bir şoför ...çünkü biri artıyor ve ...buna doğru orantı denir. Ters orantı birçokluktan biri artıyor ve diğeri de aynı oranda ... birisi azalırken diğeri de aynı oranda artıyorsa buna ters orantı denir. Bir inşaatı 10 işçi 40 günde yaparsa 7 işçi kaç günde yapar? (Ö8)

D $19(2 x)^{3}$ ve $2 x^{3}$ cebirsel ifadesi birbirine eşittir. Çünkü sonuçlar aynıdır. Karesiyle çarpınca doğru çıkar. $2.6=6 \quad 3.2=6 \quad 6.6=36(\ddot{O} 21)$

E $20 x$ birim kare 3 artarsa karenin kenarı 3 birim artar... sonuç $18^{\prime}$ 'dir. $3 \times 3 \times 3 \times 3=18$ (Ö24)

19 Eşit değildir çünkü birisi parantezin içinde birisi de parantezin dışındadır. Bunun için birbirine eşit değildir (Ö27)

Tablo 4'e göre, A seviyesindeki öğrenciler genel olarak çalışmanın başında, ortasında ve sonunda fazla ayrıntılı ve diğer seviyedeki öğrencilere göre çok daha anlaşılır ifadeler yazmışlardır. Ö2 çalışmanın başlarında 
yapılan 2. uygulamada doğruların birbirine göre durumlarını ayrıntılı açıklamıştır. Çalışmanın ortalarındaki 11. uygulamada ise laboratuvarda mevcut sıcaklık ile ulaşılmak istenen sıcaklık farkını $36^{\circ} \mathrm{c}$ olarak hesaplamış daha sonra 1 saatteki sıcaklık değişimini hesaplamıştır. Ardından 5 saatteki sıcaklık değişimini bularak başlangıçtaki sıcaklıktan çıkartarak doğru sonuca ulaşmıştır. Sonlarda yapılan 19. uygulamada ise cebirsel ifadelerin parantezin yerinden kaynaklanacak durumdan dolayı eşit olmayacağını ayrıntılı bir şekilde açıklamıştır. Ayrıca bu seviyedeki öğrenciler uygulamaları cevaplarken örnekler yazmışlardır. Ö3, 6. uygulamada negatif sayıların 10 ile çarpılınca küçüleceğini belirterek örnekleri yazmıştır.

Tablo 4'de B seviyedeki öğrencilerden Ö7 çalışmanın başındaki 4. uygulamadaki soruyu cevaplarken ayrıntılı bir cevap yazmamıştır. Sadece matematiksel sembol kullanarak açıklama yazmıştır. Ancak aynı öğrenci çalışmanın ortalarındaki 17. etkinliğine daha ayrıntılı cevap yazmıştır. Ö7 çalışmanın sonlarında yer alan 23 . etkinlikte silginin bir kenarını x sembolü ile göstermiştir. Ardından kitabın kısa kenarını, silginin 3 kez eklenip 6 cm eksik kaldığını belirtmek için $3 x+6$ cebirsel gösterimi yerine, daha ayrıntılı olacak şekilde " $x+x+x+6$ " cebirsel gösterimini tercih etmiştir. Kitabın uzun kenarını benzer olarak " $x+x+x+x+x-2$ " şeklinde ayrıntılı olarak göstermiştir. Ancak öğrenci her iki durumu çarpma işlemini kullanarak da ifade etmiştir. Bu seviyedeki öğrenciler çalışmanın başında yapılan etkinliklere görsel olarak algıladıkları biçimde açıklamalar yazmış olsalar bile bu açıklamalarını matematiksel bilgi ile ilişkilendirmişlerdir. Ö7, 2. Etkinliğine "şekilde görüldü̈̆̈̈ gibi $d$ ve $e$ doğruları birbirine paralel olarak çizilmiştir" açıklamasından sonra "e doğrusunun açısı d doğrusunun açısına eşittir” açıklamasını yazmış ayrıca şekil üzerinde açıların değerini hesaplamıştır. Ö7, 22. etkinlikte anlattıklarını örneklemek için hikâye yazmıştır. Ö7 denklem çözümünü “1. kasabada x virüsü var. 2. kasabada virüs yok. 1. kasabadakiler 2. kasabaya geçmek için işaret değiştirmeleri gerekiyor. 1. kasabaya geçmek isteyenleri jandarma durdurarak işaret değiştirmelerini istiyor..." şeklinde açıklama yazmıştır. Benzer olarak Ö33 aynı yazma etkinliğine "mesela $\mathrm{y}+4=14$ sonucunu bulmayı şöyle anlatayım sana y hasta ve bulaşıcı bir hastalığı var. Bu yüzden 4 diğer köye gitmesi için köprüden geçmesi gerek. Ama jandarmaya yakalanıyor ve jandarma herhangi bir hastalık olabilir diye onun işaretini değiştiriyor ve $+4,-4$ olarak köye gidiyor. Sonuçta y=10" açıklama yazmıştır. Öğrenciler açıklamalarını örneklendirmişlerdir.

Tablo 4'de C seviyesindeki Ö8 çalışmanın başlarındaki 2. uygulamaya yazdıkları açık, anlaşılır ve net değildir. Çalışmanın ilerleyen uygulamalarında Ö8 daha açık, net ve anlaşılır ifadeler yazmıştır. Çalışmanın sonlarında yapılan 24. uygulamaya Ö8 oran ve orantı kavramlarını örnek vererek açıklayabilmiştir. C başarı seviyesindeki öğrencilerde genel olarak çalışmanın başında, ortasında ve sonunda açıklama yaptıkları görülmüştür. Ancak bu açıklamalar çalışma başlarında çok açık ve net olmamasına rağmen çalışma sonlarına doğru daha açık, anlaşılır ve nettir. Bu seviyede bazı öğrencilerin çalışmanın başlarında uygulamaya cevap olarak ilgisiz açıklamalar yapmalarına rağmen çalışmanın orta ve sonlarına doğru uygulamalar ile ilgisiz açıklamalar yapmamışlardır. Ö8 çalışmanın başlarında yer alan 1. uygulamaya yazdığg açıklamalar doğruların birbirine göre durumları konusu ile ilgisiz olarak üçgen, yamuk ve paralelkenardan bahsetmektedir. Bu öğrenci 2. ve 6. uygulamalara soru ile ilgisi olmayan, gereksiz açılamalar yazmasına rağmen bundan sonraki uygulamalarda gereksiz ve ilgisiz açıklamalar yazmamıştır. Bu seviyedeki öğrencilerin bazıları görsel olarak algıladıkları biçimde açıklamalar yazmışlardır. Bazı öğrencilerin yazdıkları yanlış olsa bile matematiksel bilgi ile ilişki kurmaya çalışmışlardır. Ö14, 2. Uygulamaya görsel olarak algıladığ1 şekilde “Ayşe’nin dediği doğrudur. Çünkü d ve e doğruları birbiri ile istediği kadar uzatılsın çakışmazlar” cevabını yazmıştır. Öğretmen Ö14'ye doğruların niçin kesişmediklerini sorduğunda "öğretmenin birbirine paralel görünüyorlar" şeklinde cevap vermiştir. Öğrencilerden bazılarının çalışmanın başlarında yazdıklarını içselleştirdikleri sonlara doğru ise birbiri ile çelişen açıklamalar yapmadıkları görülmüştür. Örneğin, Ö8 14. Uygulamada, önce 4/6'nın 2/3'ün 2 katı olduğunu yazmasına rağmen daha sonra rasyonel sayıların eşit olabilmesi için pay ve paydanın aynı sayı ile çarpılması gerektiğini belirtmiştir. Bu iki ifade birbirinin zıttır ve öğrencinin yazdıklarını içselleştirmediğini göstermektedir. Aynı öğrencinin daha sonraki uygulamalarda buna benzer hatası tespit edilmemiştir.

Tablo 4'de D seviyesindeki öğrencilerin çalışmanın başlarındaki bazı uygulamalara cevap olarak ilgisiz açıklamalar yapmalarına rağmen çalışmanın ortalarında ve sonlarına doğru ise uygulamalar ile ilgisiz açıklamalar yapmadıkları belirlenmiştir. Ö21, 2. etkinliğe aşağıdaki gibi konu ile ilgisiz hatta dik açı yerine dik doğru, doğru açı yerine paralel doğru yazmıştır. Ancak öğrenci çalışmanın sonlarındaki uygulamalara bu şekilde açıklamalar yapmamıştır. Ö6 ise çalışmanın ortalarında yapılan 18. uygulamaya cevap yazarken, gördüğü bütün sayıları toplamıştır. Araştırmanın sonlarında öğrencilerin Ö21 gibi yazdıkları yanlış olsa bile yazdıklarını matematiksel bilgi ile ilişkilendirmeye çalışmışlardır.

Tablo 4'de E seviyesindeki öğrencilerin açıklamaları yeterince açık, anlaşılır ve net olmadığı belirlenmiştir. Çalışmada veri toplama aracı olarak kullanılan yazma uygulamalarının ilk etkinliklerinden 2. uygulamaya Ö24, etkinliğin sorusunu hatalı olarak cevaplamıştır. Ö24'ün cevabı okuyucunun anlayacağı kadar açık, anlaşılır ve ifadeleri net olarak yazmadığını, eksik yazdığını göstermektedir. Konu ile ilgisiz açıklamalar yazmıştır. Çünkü doğruda açılar konusunda paralelkenar kavramına hiç değinilmemiştir. Ö24 çalışmanın sonlarında yapılan 20. uygulamaya verdiği cevap yanlış olmakla birlikte, ayrıntılı yazılmamış ve yeterince açıklama yapılmamıştır. Bu seviyedeki öğrenciler soruların cevabını görsel olarak algıladıkları şekilde açıklama yapmışlardır. Örneğin Ö27 
araştırmanın sonlarında yapılan 19. uygulamaya verdiği cevapta matematiksel hesaplama yapılmadan, görsel olarak parantezlerin konumuna göre açıklama yazmıştır.

\subsection{1. Öğrencilerin ADPA'nın “Açıklamaların Özelliği”” Temasından Aldıkları Puanların Ortalamaları}

Öğrencilerin ADPA’nın “açıklamaların özelliği” temasından aldıkları puanların ortalamaları Şekil 20'de sunulmuştur. Puanlama yapılmadan önce 1.-8. uygulamalar (1. ve 8. dahil) başta, 10.-17. uygulamalar (10. ve 17. dahil) ortada, 19-26. uygulamalar (19. ve 26. dahil) sonda olmak üzere 3 kısma ayrılmıştır. Baştaki uygulamalar ile ortadaki uygulamalar arasında kalan 9. uygulama ve ortadaki uygulamalar ile sondaki uygulamalar arasında kalan 18. uygulama dahil edilmemiştir.

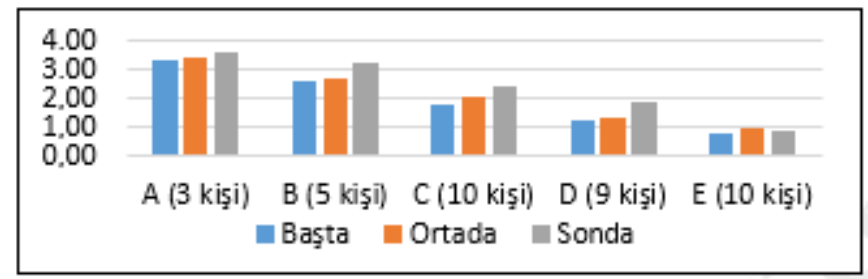

Şekil 5. Öğrencilerin ADPA’nın açıklamaların özelliği temasından aldıkları puanların ortalamaları

Şekle 5'e göre A ve E seviyesindeki öğrencilerin başta, ortada ve sonda aldıkları puanların ortalamaları arasında belirgin bir fark yoktur. B, C ve D seviyesindeki öğrencilerin sonda aldıkları puanların ortalamalarının $\operatorname{arttığ} 1$ belirlenmiştir. Tüm zaman dilimi için uygulamalarda yapılan matematiksel açıklamaların anlaşılırlığ temasında en başarısız grubun E olduğu belirtilebilir. Ayrıca çalışmada yapılan uygulamaların tüm zaman aralığında (başta, ortada ve sonda) başarı seviyesine göre gruplara ayrılan öğrencilerin puanlarının ortalamaları arasında fark olduğu belirlenmiştir.

\section{2. “Matematiksel Dili Kullanma” Temasindan Elde Edilen Bulgular}

Akademik başarılarına göre ayrılmış öğrencilerin uygulamalara verdiği yazılı cevaplar, matematiksel dili kullanma teması altında incelenerek oluşturulan kodlar Tablo 4'de sunulmuştur. Bu kodlara hangi öğrencilerin kâğıtlarından ulaşıldığı, çalışmanın hangi aşamasında yapılan uygulamalarda karşılaşıldığı tabloda belirtilmiştir.

Tablo 5. Matematiksel dili kullanma temasına göre oluşturulan kodlarda yer alan öğrenciler

\begin{tabular}{|c|c|c|c|c|c|c|}
\hline & 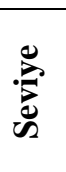 & $\begin{array}{c}\text { Matematiksel } \\
\text { sembol } \\
\text { kullanma }\end{array}$ & $\begin{array}{c}\text { Matematiksel } \\
\text { kelime kullanma }\end{array}$ & $\begin{array}{c}\text { Matematiksel } \\
\text { şekil kullanma }\end{array}$ & $\begin{array}{c}\text { Kendine } \\
\text { özgü kelime } \\
\text { ve sembol } \\
\text { kullanma }\end{array}$ & $\begin{array}{c}\text { Farklı } \\
\text { sembollerin } \\
\text { kullanımının } \\
\text { farkında olma }\end{array}$ \\
\hline \multirow{5}{*}{ 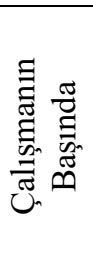 } & $\mathrm{A}_{3}$ & Ö1, Ö2, Ö3 & Ö2,Ö1, Ö3 & Ö2, Ö1, Ö3 & $\begin{array}{ll}------ \\
\end{array}$ & \\
\hline & $\mathrm{B}_{5}$ & Ö5, Ö7, Ö33 & Ö6,Ö4 & Ö33, Ö5 & Ö33 & \\
\hline & $\mathrm{C}_{10}$ & $\begin{array}{c}\text { Ö9, Ö10, Ö11, } \\
\text { Ö8, Ö14 }\end{array}$ & Ö12, Ö9 & Ö14, Ö12, Ö9 & $\begin{array}{l}\text { Ö31, Ö9, Ö14, } \\
\text { Ö12, Ö34 }\end{array}$ & \\
\hline & $\mathrm{D}_{9}$ & Ö15, Ö35 & Ö21,Ö35, Ö20 & Ö18 & Ö18, Ö22 & \\
\hline & $\mathrm{E}_{10}$ & Ö32, Ö27 & Ö27, Ö25 & Ö25, Ö23 & Ö32 & \\
\hline \multirow{5}{*}{ 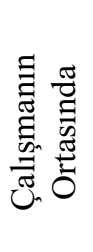 } & $\mathrm{A}_{3}$ & Ö1, Ö3, Ö2 & Ö2, Ö1, Ö3 & Ö1, Ö3, Ö2 & Ö3 & Ö3, Ö2, Ö1 \\
\hline & $\mathrm{B}_{5}$ & Ö33, Ö4, Ö7 & Ö7,Ö6, Ö26,Ö4 & Ö33, Ö6 & Ö5, Ö4 & Ö6,Ö4 Ö5, Ö33 \\
\hline & $\mathrm{C}_{10}$ & Ö9, Ö34, Ö10 & $\begin{array}{l}\text { Ö11, Ö9, Ö14, } \\
\text { Ö10, Ö34 }\end{array}$ & Ö9, Ö12, Ö14 & Ö10, Ö9, Ö13 & $\begin{array}{l}\text { Ö14, Ö10, Ö9, } \\
\text { Ö31, Ö11, Ö8 }\end{array}$ \\
\hline & $\mathrm{D}_{9}$ & Ö19, Ö16 & Ö20, Ö18, Ö35, Ö17 & Ö19, Ö18 & Ö20, Ö35, Ö19 & ------ \\
\hline & $\mathrm{E}_{10}$ & Ö30, Ö26 & Ö24, Ö27, Ö25 & Ö25, Ö23, Ö24 & Ö30 & \\
\hline \multirow{5}{*}{ 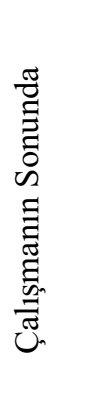 } & $\mathrm{A}_{3}$ & Ö2, Ö3, Ö1 & Ö2, Ö3,Ö1 & Ö2, Ö1, Ö3 & Ö1 & Ö2, Ö3, Ö1 \\
\hline & $\mathrm{B}_{5}$ & $\begin{array}{l}\text { Ö5, Ö33, Ö7, } \\
\text { Ö4, Ö6 }\end{array}$ & $\begin{array}{c}\text { Ö5, Ö33, Ö7, Ö4, } \\
\text { Ö6 }\end{array}$ & $\begin{array}{c}\text { Ö33, Ö4, Ö6, } \\
\text { Ö7, Ö5 }\end{array}$ & ----- & $\begin{array}{c}\text { Ö4, Ö7, Ö33, } \\
\text { Ö6 }\end{array}$ \\
\hline & $\mathrm{C}_{10}$ & $\begin{array}{c}\text { Ö9, Ö34, Ö31, } \\
\text { Ö12, Ö10, } \\
\text { Ö13,Ö14 }\end{array}$ & $\begin{array}{c}\text { Ö13, Ö8, Ö34, } \\
\text { Ö10, Ö9,Ö11,Ö14 }\end{array}$ & $\begin{array}{l}\text { Ö31, Ö8, Ö10, } \\
\text { Ö12, Ö11, Ö13, } \\
\text { Ö14 }\end{array}$ & ------- & $\begin{array}{l}\text { Ö9, Ö10,Ö14, } \\
\text { Ö12, Ö31, Ö9 }\end{array}$ \\
\hline & $\mathrm{D}_{9}$ & Ö20, Ö18, Ö22 & $\begin{array}{c}\text { Ö20, Ö21, Ö15, } \\
\text { Ö22, Ö18 }\end{array}$ & $\begin{array}{c}\text { Ö20, Ö21, Ö16, } \\
\text { Ö17, Ö22 }\end{array}$ & $\begin{array}{l}\text { Ö15, Ö22, } \\
\text { Ö16 }\end{array}$ & 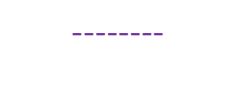 \\
\hline & $\mathrm{E}_{10}$ & $\begin{array}{c}\text { Ö28, Ö32, Ö25, } \\
\text { Ö30 }\end{array}$ & $\begin{array}{c}\text { Ö26, Ö30 Ö27, } \\
\text { Ö24,Ö37 }\end{array}$ & Ö30, Ö28, Ö32 & Ö26, Ö24 & \\
\hline
\end{tabular}

Tablo 5'e göre, matematiksel sembol kullanma kodunda, tüm seviyedeki öğrencilerin sembol kullandıkları görülmüştür. E seviyesindeki öğrencilerin kelime kullanımları sınırlıdır. Kelime kullanımlarında belirgin bir artış 
yoktur. D seviyesindeki öğrencilerin matematiksel kelime kullanımı istenen düzeyde olmamasına rağmen $\mathrm{E}$ seviyesindeki öğrencilere göre daha yoğundur. $\mathrm{B}$ ve $\mathrm{C}$ seviyesindeki öğrencilerin matematiksel kelime kullanımlarını zamanla arttırmıştır. A seviyesindeki öğrenciler ise çalışmanın başında, ortasında ve sonunda istenen seviyede matematiksel kelime kullanmışlardır. Matematiksel şekil çizme koduna göre E seviyesindeki öğrencilerin yeterince şekil çizmedikleri belirtilebilir. D seviyesindeki öğrencilerin şekil çizimi belirgin olarak artış göstermiştir. C ve B seviyesindeki öğrencilerin şekil çizimi çalışmanın sonlarında yoğunlaşmıştır. A seviyesinde çalışmanın her aşamasında şekil çizimi vardır. Kendine özgü kelime ve sembol kullanma kodunda, E ve D seviyesindeki öğrencilerde kendine özgü kelime ve sembol kullanımı vardır. Ancak bu öğrencilerde bir artıştan söz edilemez. Ayrıca C ve B seviyesindeki öğrenciler çalışmanın başlarında kendine özgü kelime ve semboller kullanmış olsa bile çalışmanın sonlarında kendine özgü kelime ve sembol kullanımı yoktur. A seviyesinde bir öğrenci dışında kendine özgü kelime kullanımı tespit edilmemiştir. Farklı sembollerin kullanımının farkında olma koduna göre, E ve D seviyesindeki öğrencilerin farklı sembol kullanımının farkında olmadıkları, diğer seviyedeki öğrencilerin farkında oldukları söylenebilir.

Tablo 6'da öğrencilerin uygulamalara verdikleri yazılı cevaplardan matematiksel dili kullanma teması ile ilgili örnek alıntılar sunulmuştur.

Tablo 6'ya göre A seviyesindeki öğrencilerden olan Ö1, 2. uygulamada iki doğrunun paralel olduğunu belirtmek için “//" sembolü kullanmıştır. Ö1, bu seviyedeki diğer öğrenciler 3. uygulamaya cevap yazarken pozitif, negatif kelimelerinin yanında + ve - sembollerini ve bunlar arasındaki çarpma işlemi sonuçlarının pozitif veya negatif olacağını göstermiştir. Ö1 çalışmanın ortalarında yapılan 8. uygulamaya cevap yazarken önce negatif tamsayıların her birini “-1” sembolü ile göstermiştir. Ö1 araştırmanın sonlarındaki 20. uygulamaya karenin kenarının 3 birim artmasını aşağıdaki sunulduğu gibi belirterek karenin çevresini ve alanını hesaplamıştır. Öğrenci burada karenin çevresini sembol kullanarak iki farklı şekilde belirtebilmiştir. Bu seviyedeki öğrencilerden Ö1 çalışmanın ilk uygulamasında konu ile ilgili olarak "paralel doğru", "kesişen doğru" ve "dik doğru" kelimelerini yoğun olarak kullanmıştır. Bu öğrenci ilaveten "çakışık" kelimesini de kullanmıştır. Ö1, 2. Uygulamaya açıklama yazarken "paralel”, "yöndeş açı”, "ters açı”, "iç ters açı”, "dış ters açı", "kesişme” kelimelerini kullanmıştır. Ö1 çalışmanın ortalarında yapılan 10. uygulamaya diğer öğrencilerden farklı olarak "işlem önceliği”" matematiksel kelimesini kullanmıştır. Ö3 doğrular ve açılarla ilgili olarak yapılan ilk iki uygulamada kullandığı matematiksel kelimelere örnek olarak, "paralel doğru”, "kesişme”, bütünler açı", "kesen" verilebilir. Burada ilk uygulamalar olmasına rağmen öğrencinin matematiksel kelimeleri kullandı̆̆ görülmektedir. Ö3 çalışmanın sonlarında yapılan 21. uygulamada "denklem”, “eşitlik”, “denklem çözümü”, "bilinmeyen" vb. matematiksel kelimeleri kullanmıştır.

Öğrencilerin çizdikleri şekiller incelendiğinde, Ö2 çalışmanın 2. uygulamasında d ve e doğrularının paralel olduğunu, ne kadar uzatılırsa uzatılsın kesişmeyeceklerini belirtmiştir. Ö2 çalışmanın sonlarında yapılan 22 . uygulamaya şekil çizmiştir. Bu seviyedeki öğrencilerin Ö3 dışında hiçbirinde kendine özgü kelimelere rastlanmamıştır. Ö3 ise sadece 13. uygulamaya cevap yazarken rasyonel sayıların, tamsayı ve doğal sayıları kapsamasını kastederek rasyonel sayı kümesi için “ailenin en büyüğü” kelimesini kullanarak kendine özgü olarak açıklamaya çalışmıştır.

Tablo 6'ya göre B seviyesindeki öğrencilerden Ö33 çalışmanın ilk uygulamasında istenen matematiksel kelimeleri kullanamamıştır. Ancak öğrencinin "paralel”, "kesen” ve "dik kesen” kelimelerini kullandığ 1 görülmüştür. 2. uygulamada ise öğrenci "kesişme", "iç ters açı" ve "dış ters açı" kelimelerini kullanmıştır. Aynı öğrenci 6. uygulamada "negatif tam sayılar” yerine “(-) işaretli sayılar” ifadesini yazmıştır. Ancak Ö33 çalışmanın ortalarında yer alan 16. uygulamada "ondalık kesir" kelimesinden bahsederek doğru bir şekilde kullanmıştır. Yine benzer olarak bu seviyedeki Ö7 çalışmanın ilk etkinliğinde cevap yazarken ilgisiz olarak “üçgen” kelimesini kullanmıştır. Ancak bunun dışında konu ile ilgili olarak "paralel” kelimesini de kullanmıştır. Diğer uygulamalarda öğrenci ilgisiz kelime kullanmamıştır. Ö7 çalışmanın ortalarında yapılan 13. uygulamaya cevap yazarken "bileşik kesir", "pay”, "payda", "tamsayı" kelimeleri kullanmıştır. Aynı öğrenci çalışmanın sonlarında uygulamalara cevap yazarken "denklem”, "bilinmeyen”, “çözüm kümesi”, "doğru orantı”, “ters orantı" vb. konu ile ilgili kelimeleri sıklıkla kullanmıştır. Bu seviyedeki öğrencilerden Ö4, bilinmeyen yerine $\mathrm{x}$, $\mathrm{y}$ ve a gibi harflerin yazılabileceğini belirttikten sonra y ve a harflerinin de $\mathrm{x}$ ile aynı anlam taşıyacağını belirtmiştir. Öğrenci burada, x'in bilinmeyen olarak daha fazla kullanılmasına rağmen y ve a'nın da aynı anlamı taşıyacağını belirtmesi, matematiksel sembolleri kullanımının farkında olduğunu gösterebilir. 
Tablo 6. Matematiksel dili kullanma temasına göre öğrenci cevaplarından örnekler

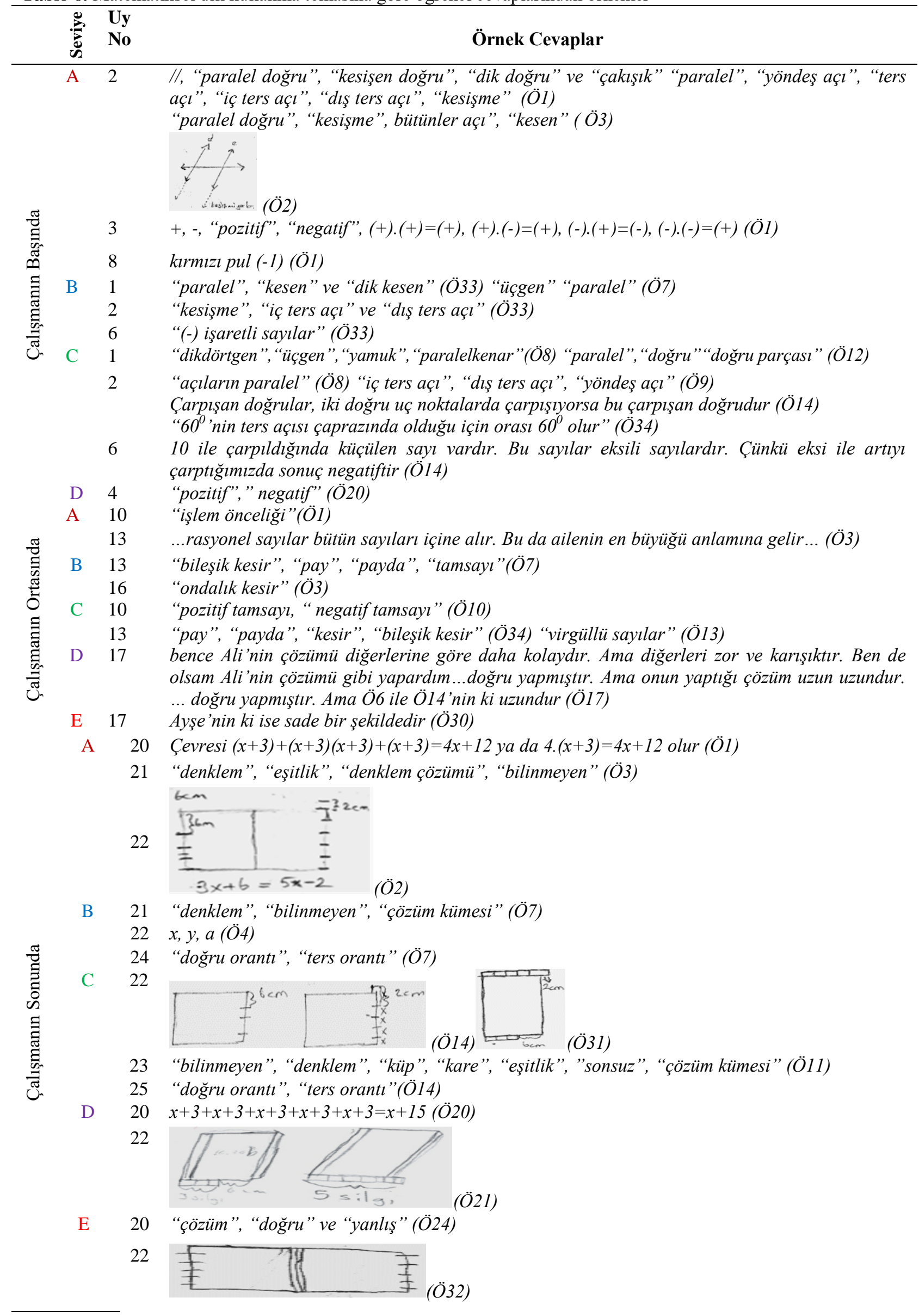


25 Doğru orantı 2 tarafta da aynı işi yapar (Ö24)

Tablo 6'ya göre C seviyedeki Ö8 çalışmanın başında yapılan 1. uygulamaya ilgisiz olarak "dikdörtgen", "üçgen", "yamuk" ve "paralelkenar" kelimelerini konu ile ilgisiz olarak kullanmıştır. Daha sonraki uygulamada da doğruların paralelliğinden bahsederken "açıların paralel" olacağını belirtmiştir. Ancak diğer uygulamalarda buna benzer durumla karşılaşılmamıştır. Öğrenci yanlış cevap yazdığı uygulamalarda bile ilgisiz kelime kullanmamıştır. C seviyesindeki öğrencilerin çalışmanın ilk uygulamalarında akademik başarısı çok düşük ve düşük öğrencilere göre daha yoğun matematiksel kelime kullandıkları belirlenmiştir. Örneğin ilk uygulamalarda "paralel", "doğru”, "doğru parçası", "iç ters açı", "dış ters açı", "yöndeş açı" vb. ortadaki uygulamalarda yine akademik başarı seviyesi düşük ve çok düşük olan gruplara göre daha yoğun matematiksel kelime kullanımı vardır. Örneğin "içler dışlar çarpımı", "pozitif tamsayı, " negatif tamsayı", "pay", "payda", "kesir", "bileşik kesir" vb. Çalışmanın sonundaki uygulamalarda "bilinmeyen", "denklem", "doğru orantı", "ters orantı", "küp", "kare", "eşitlik", "sonsuz", "çözüm kümesi" matematiksel kelimelerin kullanımı vardır. Bu seviyedeki öğrencilerin araştırmanın başlarında kendilerine özgü kelime kullandığı tespit edilmiştir. Ö14, 1. uygulamada "kesişen doğru" yerine kendine özgü olarak "çarpışan doğru" ifadesini kullanmıştır. Yine aynı öğrenci 6. uygulamada "negatif sayılar" yerine kendine özgü olarak "eksili sayılar" ifadesini kullandı̆̆ görülmektedir. Ö13, çalışmanın ortasında uygulamada ondalık sayılar yerine "virgüllü sayılar" ifadesini kullanmıştır. Bu seviyedeki öğrencilerden olan Ö34, 2. uygulamada ters açı kavramına açıklama olarak "ters açı" ile "çapraz" kelimesini ilişkilendirmiştir. Ancak sonlarda yapılan uygulamalarda bu tür durumlara rastlanmamıştır.

Tablo 6'ya göre D seviyesindeki öğrencilerden Ö20, 4. uygulamasında “+”, “_“ yerine "pozitif”, "negatif” kelimelerini kullanmayı tercih etmiştir. Öğrenciler sembol yerine kelime kullanmayı tercih etmişlerdir. Ö20 çalışmanın sonlarındaki 20. uygulamada sembolleri doğru kullanmasına rağmen bu semboller arasındaki işlemi yanlış cevaplamıştır. Öğrenci burada sayıları toplamasına rağmen, $x$ değişkenini toplamamıştır. D seviyesindeki öğrencilerin şekil çizmelerinde artı̧̧ göstermiştir. Ancak bazen şekil ile soru arasında ilişki kuramamışlardır. Ö21 çalışmanın sonlarında yapılan 22. uygulamada şekillerin biri ile ilişki kurmasına rağmen diğeri ile ilişki kuramamıştır. Öğrenci soldaki şekilde kitabın kısa kenarının ölçümünde silginin 3 kez uç uca eklendiğinde $6 \mathrm{~cm}$ eksik kalmasını göstermesine rağmen sağdaki şekilde silginin $5 \mathrm{kez}$ eklendiğinde $2 \mathrm{~cm}$ fazla gelmesini gösterememiştir. D seviyesinde, farklı sembollerin kullanımının farkında olma koduna göre öğrenci yazıları incelendiğinde, Ö17 rasyonel sayıların farklı gösterimleri ile ilgili olan 17. uygulamada gösterimlerden bahsetmemesi uygulamadaki soru çözümlerine bakarak yorum yazdığını göstermektedir.

E seviyedeki öğrencilerin kelime kullanımları sınırlı ve kullandıkları kelime çeşidi azdır. Öğrencilerin uygulamalara cevap yazarken kullandıkları kelimeler genellikle uygulama kâğıdında soruyu ifade ederken kullanılan kelimelerden oluşmaktadır. Bu seviyedeki tüm öğrencilerde uygulama başlarında ilgisiz matematiksel kelime kullandığı, matematiksel kelime kullanımında belirgin bir artış olmadığı belirlenmiştir. Örneğin Ö37 çalışmanın sonlarında yapılan 20. uygulamasında çok fazla matematiksel kelimenin kullanılabileceği uygulamada öğrenci neredeyse hiç matematiksel kelime kullanmamıştır. Bu başarı seviyesinde olan başka bir öğrenci de benzer olarak aynı uygulamada "çözüm", "doğru" ve "yanlış" kelimelerini kullanmış onun dişında matematiksel kelime kullanmamıştır.

E seviyesindeki öğrencilerden bazıları hiç şekil çizmezken, bazıları da şekil çizmiş ancak uygulama ile ilişkilendirmemiştir. Ö32 çalışmanın sonlarındaki 22. uygulamada çizdiği şekil Tablo 6'da sunulmuştur. Öğrenci sadece kitap resmi çizmeye çalışmıştır. Bu seviyedeki öğrencilerden bazıları kendine özgü ifadeler kullanmıştır. Örneğin, sonlarda uygulanan 25. etkinliğine Ö24 "doğru orantı 2 tarafta da aynı işi yapar" ifadesini yazmıştır. Öğrenci yeterince açıklama yapmamış olsa da doğru orantılı iki çokluktan biri azalırken diğeri de azalır. Biri artarken diğeri de artar kuralını açıklamak için kendine özgü ifadeler kullanmıştır. Yine benzer şekilde Ö30, Tablo 6'da sunulan örnekte, 17. uygulamada bileşik kesre çevirme işlemini kendine göre "sadelik" kelimesiyle açıklamaktadır.

B seviyedeki Ö5'de farklı sembollerin kullanımının farkındadır. Ö5, 14. uygulamada 6/9, 18/27, 54/81 sayılarının 2/3 rasyonel sayılarına eşit olduğunu belirtmiştir. Benzer olarak 17. uygulamada da bileşik kesirlerin, tamsayılı kesirlerin tamsayı ve basit kesir cinsinden yazılabileceğini ifade etmiş̧ir. Bu başarı seviyesinden diğer öğrencilerden Ö33 ve Ö4'de aynı uygulamalara benzer cevaplar yazmıştır. Ö4 çalışmanın sonlarındaki 22. uygulamada "y, a" sembollerinin " $x$ " sembolü ile aynı anlamda kullanılabileceğini belirtmiştir.

C seviyedeki öğrencilerden Ö14, 8. uygulamada temsil eden model olarak $(+12):(+2)=(+6)$ yazmıştır. Burada öğrenci kırmızı pulların negatif sayıları temsil etmesi gerektiğini dikkate almamıştır. Aynı öğrenci çalışmanın sonlarında yapılan 19. uygulamada $(2 \mathrm{x})^{3}$ ile $2 \mathrm{x}^{3}$ ifadesinin aynı olmadığını "birincisinde parantezin küpünü al demektir. $2 \mathrm{x}^{3}$ ise yalnızca küpünü al demektir. Bu yüzden bunların ikisi eşit değildir” şeklinde ifade yazmıştır. Öğrencinin sembolleri doğru olarak kullandığı anlaşılmaktadır. C seviyesindeki öğrencilerden Ö14 ilk uygulamada paralelkenar çizerek, şeklin yanına "paralel doğruya yani bu şekle eşittir çünkü birbirine yatay gittikleri için paralel doğrudur" şeklinde açıklama yazmıştır. Ancak yeterli ilişkiyi kuramamıştır. Aynı öğrenci çalışmanın ortalarında yapılan 18. uygulamada çemberler çizerek kesirleri bunları içerisine yazmışır. Ancak 
problemde yer alan hiç takım tutmayan 5 kişiyi de kesirlerde olduğu gibi şekil içerisine yerleştirmiştir. Öğrenci kesirler ile 5 sayısını aynı mantık içerisinde kullanmıştır. Hâlbuki soruda verilen 5/12 vd. kesirleri öğrencilerin 5/12'si şeklindedir. Yani 5 tam sayısının belirttiği mantıkla aynı anlamda değildir. Öğrenci burada şekil çizerek ilişki kurmaya çalışmıştır. Ancak istenen düzeyde bunu yapamamıştır. Aynı öğrenci çalışmanın sonlarındaki 22. uygulamaya Tablo 6'da verilen şekli çizmiştir. Öğrenci burada şekil çizerek, soru ile arasında ilişki kurmaya çalışmıştır. Benzer olarak bu seviyedeki Ö31, 22. uygulamada Tablo 6'da verilen şekli çizmiştir. Öğrenci burada akademik başarı seviyesi düşük ve çok düşük olan öğrencilerden farklı olarak, aynı şeklin birbirine eşit farklı kenarları üzerinde silgiyi 3 kez ve 5 kez ekleyerek, artmayı ve fazla gelmeyi doğru bir biçimde gösterebilmiştir.

D seviyesindeki öğrencilerden Ö17 çalışmanın başında yapılan 4. uygulamada hiç sembol kullanmamıştır. Bunun yerine açıklamalarını kelime kullanarak yapmıştır. Bu seviyedeki öğrencilerden bazıları aynı konuda kullanılan kelimeleri, birbirlerinin yerine kullandıkları belirlenmiştir. Örneğin "kenar" yerine "köşe" kelimesini, "açı ölçüsü” yerine "açı” kelimesini, "dik açı” yerine "dik doğru” kelimesini kullanmışlardır. Ancak araştırmanın sonlarında bu tür kelime kullanımına rastlanmamıştır.

E seviyesindeki öğrenciler sembol kullanmışlardır. Ancak bu sembollerin kullanım şekli doğru değildir. Matematiksel içerik ile sembolleri doğru olarak ilişkilendirememişlerdir. Bu seviyedeki öğrenciler genellikle geçmiş yıllarda öğrendikleri sembolleri daha doğru olarak kullanmaktadırlar. Yeni öğrendikleri matematiksel sembolleri (x, y vb.) nadiren kullanmaktadırlar. Ayrıca değişken sembolünün kullanımında ve işlemlerinde yanlışlıklar vardır. Örneğin Ö25 değişken sembolü olan x ile sayılar arasındaki farkı tespit edememiştir. "x" ile "3" sayısını topladığında sonuca " $4 x$ ” yazmıştır. Benzer olarak " $x$ " ile " 4 " sayısını topladığında " $5 x$ " yazmıştır. Öğrenci semboller arasında farkı tespit edememiştir.

\subsection{1. Öğrencilerin ADPA'nın “Matematiksel Dil Kullanımı” Temasından Aldıkları Puanların Ortalamaları}

Öğrencilerin ADPA’nın “matematiksel dil kullanımı” temasından aldıkları puanların ortalamaları Şekil 6'da sunulmuştur.

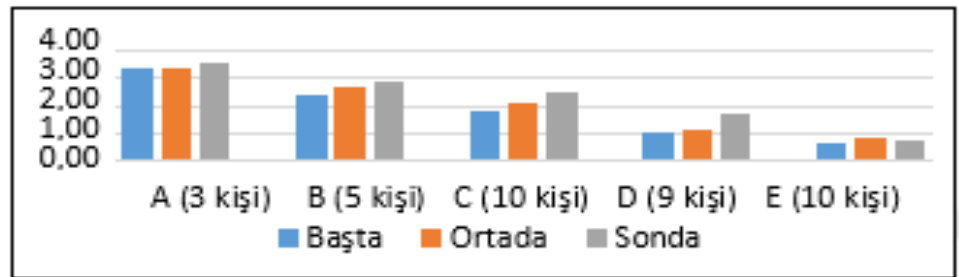

Şekil 6. Öğrencilerin ADPA’nın matematiksel dil kullanımı temasından aldıkları puanların ortalamaları

Şekil 6'daki verilerde; A ve E seviyesindeki öğrencilerin baştaki ve ortadaki puanlarının ortalamaları arasında bir fark olsa da, sondaki puanlarının ortalamaları arasında belirgin bir fark yoktur. Bu durum yazma uygulamalarının, akademik başarısı çok düşük olan gruptaki öğrencilerin matematiksel dil kullanımını belirgin bir şekilde geliştirmediğini gösterebilir.

Şekil 6'daki verilerde; B, C ve D öğrencilerin, çalışmanın başında, ortasında ve sonunda aldıkları puanların ortalamaları arasında belirgin bir artış olduğu görülmektedir. Bu durumda yazma uygulamalarının, akademik başarısı düşük, orta, yüksek ve çok yüksek olan gruptaki öğrencilerin matematiksel dil kullanımına katkı sağladığ 1 söylenebilir.

Şekil 6’ya göre, tüm zaman dilimi için uygulamalarda yapılan matematiksel dil kullanımı temasında en başarısız grubun akademik başarı seviyesi çok düşük grup olduğu belirtilebilir. Ayrıca çalışmada yapılan uygulamaların tüm zaman aralığında (başta, ortada ve sonda) başarı seviyesine göre gruplara ayrılan öğrencilerin puanlarının ortalamaları arasında fark olduğu belirlenmiştir. Bu durumda öğrencilerin kullandıkları matematiksel dilin akademik başarılarına göre farklılık gösterdiği söylenebilir.

\section{3. "Matematiksel Yapı ve Hesaplamalar” Temasindan Elde Edilen Bulgular}

Akademik başarılarına göre ayrılmış tüm öğrencilerin uygulamalara verdiği yazılı cevaplar, matematiksel yap1 ve hesaplamalar teması altında incelenerek oluşturulan kodlar Tablo 5'de sunulmuştur. Bulgular verilirken algoritma kurma ve hesaplama yapma ifadeleri kullanılmıştır. Algoritma kurma ile bahsedilmek istenen uygulamaya cevap yazılırken yapılması düşünülen tüm süreçler kastedilmektedir. Hesaplamalar ise bu süreç içerisindeki işlemlerdir. $\mathrm{Bu}$ durumda uygulamaya cevap yazılırken önce algoritma kurulur ardından hesaplamalar yapılır. Yanlış kurulan bir algoritmada hesaplamalar doğru olmasına rağmen sonuçta istenen cevaba ulaşılmayabilir.

Tablo 7'de, eksik, ilgisiz veya görsel olarak algılanan şekilde hesaplamalar yapma koduna göre, E seviyesindeki öğrenciler çalışmanın tüm zamanlarında eksik, ilgisiz veya görsel olarak algılanan şekilde 
hesaplamalar yapmışlardır. D seviyesindeki öğrenciler, E seviyesindeki öğrenciler kadar olmasa bile yine her zaman diliminde eksiz ve ilgisiz hesaplamalar yapmışlardır. C seviyesindeki öğrencilerin yaptıkları hesaplama ve algoritmalarda gelişim olduğu belirlenmiştir. B ve A seviyesindeki öğrencilerde bir gelişim olmadığ 1 söylenebilir.

Tablo 7. Matematiksel yapı ve hesaplamalar temasına göre oluşturulan kodlarda yer alan öğrenciler

\begin{tabular}{|c|c|c|c|c|}
\hline & 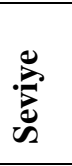 & $\begin{array}{c}\text { Eksik, ilgisiz veya görsel olarak } \\
\text { algılanan şekilde hesaplamalar } \\
\text { yapma }\end{array}$ & $\begin{array}{l}\text { Farklı yapı ve } \\
\text { hesaplama } \\
\text { yöntemi } \\
\text { geliştirebilme }\end{array}$ & $\begin{array}{c}\text { Sonucu değerlendirme } \\
\text { (sonucun doğruluğunu ve } \\
\text { mantıklılığını kontrol } \\
\text { etme) }\end{array}$ \\
\hline \multirow{5}{*}{ 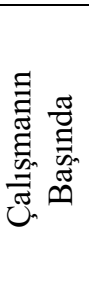 } & $\mathrm{A}_{3}$ & ------ & Ö1 & Ö1 \\
\hline & $\mathrm{B}_{5}$ & Ö33, Ö6,Ö4 & Ö33, Ö5 & ------- \\
\hline & $\mathrm{C}_{10}$ & $\begin{array}{l}\text { Ö10, Ö12, Ö34, Ö9,Ö11, } \\
\text { Ö14,Ö8,Ö31 }\end{array}$ & Ö8, Ö34 & \\
\hline & $\mathrm{D}_{9}$ & $\begin{array}{c}\text { Ö21,Ö35,Ö17,Ö16,Ö19, } \\
\text { Ö21,Ö18,Ö22 }\end{array}$ & Ö16 & ----- \\
\hline & $\mathrm{E}_{10}$ & Ö23,Ö32,Ö28,Ö26,Ö24,Ö25,Ö36,Ö29 & Ö36 & ------- \\
\hline \multirow{5}{*}{ 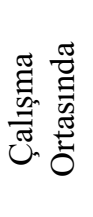 } & $\mathrm{A}_{3}$ & ------ & Ö1,Ö2,Ö3 & \\
\hline & $\mathrm{B}_{5}$ & Ö6,Ö4 & Ö5, Ö33, Ö7 & ------- \\
\hline & $\mathrm{C}_{10}$ & Ö12, Ö34, Ö14, Ö11 & Ö8, Ö10, Ö14 & Ö31 \\
\hline & $\mathrm{D}_{9}$ & Ö20, Ö17, Ö16, Ö21, Ö15, Ö19 & Ö22 & ------- \\
\hline & $\mathrm{E}_{10}$ & Ö26,Ö25,Ö29,Ö23,Ö36,Ö32,Ö28,Ö30 & -------- & ------- \\
\hline \multirow{5}{*}{ 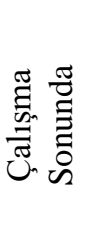 } & $\mathrm{A}_{3}$ & ----- & Ö2, Ö3 & -------- \\
\hline & $\mathrm{B}_{5}$ & Ö6,Ö4 & Ö33, Ö5, Ö4 & -------- \\
\hline & $\mathrm{C}_{10}$ & Ö34, Ö14 & Ö8, Ö31 & ------- \\
\hline & $\mathrm{D}_{9}$ & Ö16, Ö35, Ö20, Ö19, Ö15, Ö18 & Ö15 & ------- \\
\hline & $\mathrm{E}_{10}$ & $\begin{array}{l}\text { Ö25,Ö29,Ö23,Ö36,Ö28,Ö26,Ö32,Ö24 } \\
\text {,Ö30 }\end{array}$ & -------- & --- \\
\hline
\end{tabular}

Farklı yapı ve hesaplama yöntemi geliştirebilme koduna göre, E seviyedeki öğrencilerden biri dışındaki hiçbir öğrencide farklı algoritma ve hesaplamaya rastlanmamıştır. Benzer şekilde D ve C seviyelerinde de sınırlı öğrenci farklı hesap ve algoritma kullanmasına rağmen, başarı seviyesi B ve A olan öğrencilerde özellikle çalışmanın orta ve son bölümlerinde yapılan çalışmalarda farklı algoritma ve hesaplama kullanımı görülmektedir. Tablo 7'ye göre ayrıca sadece iki öğrencinin buldukları sonucun doğruluğunu ve mantıklılığını kontrol etmişlerdir.

A seviyesindeki öğrencilerin yaptıkları hesaplardaki eksiklik yok denecek kadar azdır. Ayrıca bu öğrencilerin tüm zaman aralığında yaptığı hesaplamalar ilgisiz ve görsel olarak algılanan şekilde değildir. Örneğin, Ö1, 12. uygulamada Şekil 7'de sunulan hesaplamayı yapmıştır:

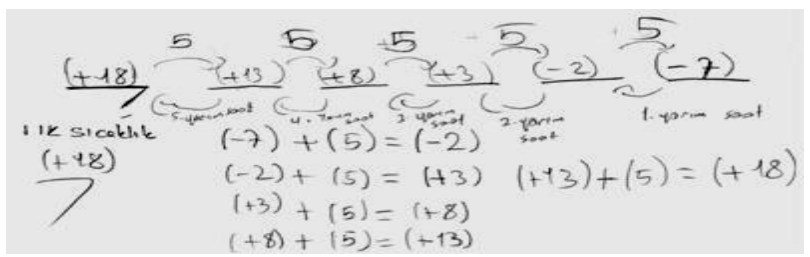

Şekil 7. Ö1'in çalışmanın ortasındaki cevabı

Öğrenci burada her yarım saatte 5 derecelik 1sı düşüşünü göstererek 3 saatin sonunda oluşan (-7) derecelik sıcaklıktan yola çıkarak ilk sıcaklığa ulaşmaya çalışmıştır. Öğrenci hesaplama yaparken son duruma 5 derece eklememiştir. Dolayısıyla eksik hesaplama yapmıştır. İstenen cevap 23 derecedir. Bu seviyedeki öğrenciler farklı çözüm algoritmaları ortaya koyabilmişlerdir. Bu öğrencilerden olan Ö1, 17. Uygulamada, bütün rasyonel sayıların paydasını eşitlemek yerine daha pratik bir çözüm yolu olarak tamsayılı kesirler diğerlerinden daha büyük olacağından onları hesaba katmamıştır. Diğer sayıları da kendi arasında inceleyerek çözüme ulaşmıştır. Yine bu başarı seviyesindeki öğrencilerden olan Ö3, 15. etkinliğine cevap yazarken sayı doğrusunda rasyonel sayıları yerleştirirken 0'ın yerini bulabilmek için öncelikle sayı doğrusunda ikiye bölmek gerektiğini belirtmiştir. Yani öğrenci -2 ile 2'nin tam ortasının “0” olacağını düşünmüştür. Benzer mantıkla diğer noktalara karşılık gelen sayıları bulmuştur. Dolayısıyla A seviyesindeki öğrencilerin uygulamalardaki sorulara farklı algoritmaları geliştirebildikleri söylenebilir.

B seviyesindeki öğrencilerin başta, ortada ve sonda yazma uygulamalarına verdiği cevaplarda eksiklik olmasına rağmen bu eksiklik E, D ve C seviyesindeki öğrenciler kadar fazla değildir. Ayrıca bu öğrencilerin 
yaptığı hesaplamalar ilgisiz ve görsel algıladıkları şekilde değildir. Örneğin, Ö4 araştırmanın başlarında yapılan 3. uygulamada algoritması doğru olmasına rağmen 16 tamsayısından 21 tamsayısını çıkardığında sonucu -5 yerine -4 olarak yanlış bulmuştur. Öğrenci 9. uygulamaya verdiği cevapta 1 . ve 2. dizinin verilmeyen terimini bulmasına rağmen 3. dizinin verilmeyen terimini hesaplayamamıştır. Benzer olarak aynı öğrenci çalışmanın sonunda yapılan 20. uygulamada karenin çevresini hesaplarken önce iki kenarın uzunluğunu " $x+6$ " olarak yanlış hesaplamış ardından " $\mathrm{x}+6$ " ile " $\mathrm{x}+6$ " ifadelerini toplarken yanlış bir şekilde cevabı " $\mathrm{x}+12$ " olarak bulmuştur. Ancak öğrenci aynı uygulamada karenin alanını doğru olarak hesaplayabilmiştir. Ö4 "oran-orant1-2" uygulamasinda “...3 musluk havuzu 5 saatte dolduruyor. 4 musluk daha kisa sürede doldurur. Biri artarken diğeri azalır...ters orantıdır...” şeklinde algoritma kurarak doğru olarak soruyu cevaplamıştır. Bu seviyedeki öğrenciler sonucun mantıklılığını kontrol etmemişlerdir. Ö4 çalışmanın sonunda yapılan "denklemler-2" uygulamasında soruda verilen duruma uygun olarak denklemi doğru kurmasına rağmen yanlış hesaplama yaparak bilinmeyen sayıyı (-2) olarak bulmuştur. Öğrenci burada x sembolünü silginin boyunun uzunluğu olarak almıştır. Dolayısıyla sonucun negatif bir tamsayı çıkmaması gerekirdi. Öğrenci bulduğu sonucun mantıklılığını düşünmemiştir.

C seviyedeki öğrencilerin yaptıkları hesaplama ve algoritmalarda iki öğrenci dışında gelişim belirlenmiştir. Örneğin, Ö11 başlarda yapılan 3. uygulamada, 7 günde azalacak sıcaklık değerini "-21" olarak bulmasına rağmen daha sonra yanlış algoritma kurarak 16 ile 21 sayılarını birbirinden çıkarması gerekirken, çarpmıştır. Aynı öğrenci 5. uygulamada da yanlış algoritma kurarak soruyu cevaplayamamıştır. Ö11, 9. uygulamada da soruda verilen 1. ve 2. dizinin terimini doğru olarak hesaplamasına rağmen 3. dizi için algoritma kuramamıştır. $\mathrm{Bu}$ öğrenci çalışmanın ortalarında yapılan tamsayılarla problem çözme uygulamalarında yanlış algoritma kurarak soruyu cevaplayamamıştır. Ancak çalışmanın sonlarında yapılan 22. uygulamada denklemleri doğru kurarak “ $3 x+6=5 x+2 "$ olarak yazabilmiştir.

D başarı seviyesindeki bazı öğrencilerin çalışmanın başındaki uygulamalarda yanlış algoritma kurarak, yanlış hesaplamalar yapmalarına rağmen, çalışmanın ilerleyen uygulamalarında sadece eksik hesaplamalar yaptıkları belirlenmiştir. $\mathrm{Bu}$ öğrencilerden Ö18 çalışmanın ortalarında yapılan 11. uygulamada, sıcaklığın 36 derece düşeceğini bulmasına rağmen geri kalan hesaplamayı yapamamıştır. Öğrenci eksik hesaplama yapmıştır. Aynı öğrenci 19. uygulamada " $2 x$ "" cebirsel ifadesini " $2 x$ " ile çarparak yanlış bir sonuç olarak cevab1 " $4 \mathrm{x}^{3}$ " olarak bulmuştur. Burada öğrenci sayıları doğru çarpmasına rağmen cebirsel ifadelerin çarpımını doğru olarak yapamamıştır. Ö18, 22. uygulamada problemi çözerken silginin boyunu hesaplamıştır. Kitabın boyunu bulması için bu sayıyı denklemde yerine koyması gerekirdi. Dolayısıyla öğrenci eksik çözüm yapmıştır. Daha sonraki uygulamada ise öğrenci karenin çevresini temsil eden " $x+4$ " cebirsel ifadesini doğru bulmasına rağmen bu ifadelerin toplamasını yaparken sonucu " $4 \mathrm{x}+12$ " yerine “ $\mathrm{x}+12$ " olarak bulmuştur. Öğrenci eksik hesaplama yapmıştır. Benzer şekilde oran-orantı uygulamalarında da eksik algoritma ve hesaplama vardır. Bu seviyedeki öğrencilerde sonucun mantıklı olup olmadığını düşünmemişlerdir. Örneğin Ö15, 8. uygulamada modeli temsil eden matematiksel işlemi $(-12)+(-12)=(+24)$ şeklinde yanlış olarak belirtmiştir. Öğrenci pulların negatif sayıları temsil ettiğini dolayısıyla sonucun negatif olması gerektiğini düşünememiştir.

E seviyedeki öğrencilerden Ö29, eksik, ilgisiz veya görsel olarak algılanan şekilde hesaplamalar yapma kodu ile ilgili olarak, 11. uygulamada, öncelikle -22 ile 14 arasındaki sıcaklık farkının 36 olacağını bulmuştur. Daha sonra 36'yı 9'a bölerek 1 saatteki sıcaklığı hesaplamıştır. Ancak soruda 5 saatin sonunda oluşan sicaklık sorulmakta olduğundan öğrenci eksik cevap yazmıştır. Aynı öğrenci 20. uygulamada karenin kenarının 3 birim artmasıyla yeni oluşan kenarın uzunluğunun $\mathrm{x}+3$ olacağını belirtmesine rağmen, karenin çevresini " $3+3+3+3=12$ " olarak eksik hesaplamıştır. Ö24 ise 3 . uygulamada yaptığ 1 hesaplamalar bu seviye grubundaki diğer arkadaşlarına benzer olarak, görsel olarak algıladıkları şekilde sayıların kendi arasında toplanıp çıkarılmasından oluşmaktadır. Uygulamada hava sıcaklığının 16 derece olduğu verilmiş, her gün 3 derece azaldığ1 belirtilmiştir. Öğrenci 16 sayısından 3 sayısını çıkararak 13 bulmuştur. 7. gün sonundaki sıcaklığ bulmak için ise 13'den 7'yi çıkartarak sonucu 6 bulmuştur. Burada kullanılan algoritma yanlıştır. Aynı öğrenci daha sonra yapılan problem çözme ve kurma ile ilgili 11. ve 12. uygulamada da aynı şekilde hesaplamalar yapmıştır. Bu başarı seviyesindeki öğrencilerin hepsi uygulamanın tüm zamanlarında eksik, ilgisiz veya görsel olarak algıladıkları şekilde hesaplamalar yapmışlardır. Ayrıca bu seviyedeki öğrenciler farklı yapı ve hesaplama yöntemi geliştirebilme koduna göre, sadece bir öğrencinin yazdıklarından bulgu elde edilmiştir. Ö36, çalışmanın başlarında yapılan 3. Uygulamada farklı hesaplama kullanarak cevaplamıştır. Öğrenci sıcaklığın 7 gün boyunca azalmasını başlangıçtaki sıcaklık olan 16 dan 7 tane 3'ü çıkararak belirtmiştir. Bu seviyedeki Ö36 dışındaki hiçbir öğrencide farklı algoritma ve hesaplamaya rastlanmamıştır.

\subsection{1. Ö̆grencilerin ADPA'nın "Matematiksel Yapı ve Hesaplamalar” Temasından Aldıkları Puanların Ortalamalart}

Öğrencilerin ADPA'nın “matematiksel yapı ve hesaplamalar” temasından aldıkları puanların ortalamaları düzenlenerek Şekil 8'de sunulmuştur. 


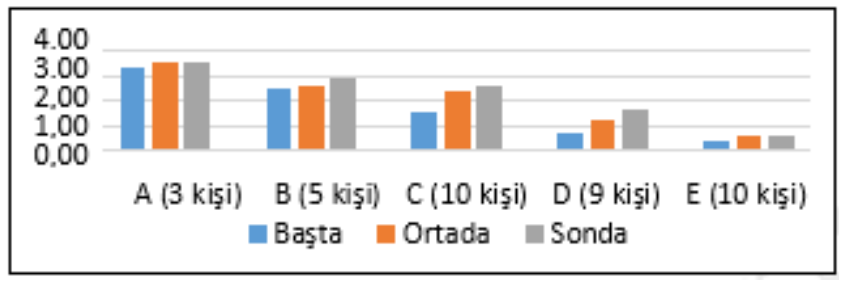

Şekil 8. Öğrencilerin ADPA’nın matematiksel yapı ve hesaplamalar temasından aldıkları puanların ortalamaları

Şekil 8'deki verilerde; A (akademik başarı seviyesi çok yüksek) ve E (akademik başarı seviyesi çok düşük) grubundaki öğrencilerin baştaki, ortadaki ve sondaki puanlarının ortalamaları arasında belirgin bir fark yoktur. $\mathrm{Bu}$ durum yazma uygulamalarının, akademik başarısı çok düşük olan gruptaki öğrencilerin matematiksel yapı ve hesaplamalarının belirgin bir şekilde geliştirmediğini gösterebilir.

Şekil 8'deki verilerde; C (akademik başarı seviyesi orta) ve D (akademik başarı seviyesi düşük) öğrencilerin, çalışmanın başında, ortasında ve sonunda aldıkları puanların ortalamaları arasında belirgin bir artış olduğu görülmektedir. Bu durumda yazma uygulamalarının, akademik başarısı düşük ve orta olan gruptaki öğrencilerin matematiksel yapı ve hesaplamalarına katkı sağladığı söylenebilir. Ayrıca şekle göre B (akademik başarısı seviyesi yüksek) öğrencilerin ortalamalarında belirgin olmayan bir yükseliş olduğu belirtilebilir.

Şekil 8'e göre, tüm zaman dilimi için uygulamalarda yapılan matematiksel yapı ve hesaplamalar temasında en başarısız grubun akademik başarı seviyesi çok düşük grup olduğu belirtilebilir. Ayrıca çalışmada yapılan uygulamaların tüm zaman aralığında (başta, ortada ve sonda) başarı seviyesine göre gruplara ayrılan öğrencilerin puanlarının ortalamaları arasında fark olduğu belirlenmiştir. Bu durumda öğrencilerin kullandıkları matematiksel yapı ve hesaplamaların akademik başarılarına göre farklılık gösterdiği söylenebilir.

\section{Tartışma ve Sonuç}

Bilişsel gelişimin çok faklı tanımları ve boyutları olmasına rağmen bu çalışmada üç farklı tema ele alınmıştır. $\mathrm{Bu}$ temalar (1) öğrencilerin yaptıkları açıklamaların özelikleri, (2) matematiksel dili kullanma ve (3) matematiksel algoritma ve hesaplamalardır. Bu üç tema altında öğrencilerin bilişsel gelişimleri incelenmiş̧ir.

Akademik başarılarına göre; çok yüksek (A), yüksek (B), orta (C), düşük (D) ve çok düşük (E) şeklinde beş gruba ayrılan öğrencilerin ADPA'nın ilk kategorisi olan açıklamaların anlaşılırlı̆̆ kısmından aldıkları puanlara göre $\mathrm{B}, \mathrm{C}$ ve $\mathrm{D}$ seviyesinde olan öğrencilerin açıklamaları üzerinde yazma uygulamalarının olumlu etkisi olduğu belirtilebilir. Diğer başarı gruplarındaki öğrencilerde belirgin bir gelişim tespit edilememiştir. Benzer olarak açıklamaların özellikleri teması altındaki ayrıntılı, açık ve anlaşılır cevap yazma kodu altında verilen nitel bulgularda da B, C ve D seviyesinde olan öğrencilerin cevaplarının anlaşılırlığının arttı̆̆ daha açık ve net açıklamalar yaptıkları belirlenmiştir. Greenes, Ginsburg ve Balfanz (2004) sınıflarda matematiksel hikâyelerin kullanılması ile birlikte matematiksel dilin kullanımının arttığını ve matematiksel açıklamaların daha nitelikli hale geldiğini belirtmiştir. Araştırmadaki bu sonucun kısmen aynı yönde olmaması kullanılan yazma uygulamasının yapısından ve çeşidinden kaynaklanabilir. Ayrıca Brandenburg (2002), matematik derslerinde yazma etkinliklerinin kullanılmasının önemli ancak aynı zamanda zor olduğunu belirtmiştir. Ona göre, tatilini nasıl geçirmeyi düşündüğü ile ilgili soruya cevap yazma belki kolay olabilir ancak, yeni öğrenilen karmaşık matematik kavramları hakkında yazılması kolay değildir. Matematik dersinde yazma, hem yazma beceri süreçlerini hem de matematiksel bilgi içeriğini gerektirdiği için gelişim olmayan E seviyesindeki öğrencilere zor gelmiş olabilir. Benzer olarak, Akarsu-Yakar ve Yılmaz (2017) 7. sınıf öğrencilerinin cebir alanı ile ilgili bir hikâye içerisindeki gerçek yaşam durumunu matematiksel ifadeye dönüştürürken, kullandıkları matematiksel dil becerilerini inceledikleri araştırmalarında, akademik başarıları yüksek olan öğrencilerin ifadeleri açıklarken yazılı, sözel ve sembolik dili doğru kullandığı, başarıları düşük olan öğrencilerinde sembolik ifadeleri oluştururken ve açıklama yaparken zorlandıkları belirtmiş̧lerdir. Özkan (2019) alan ölçme konusunda 6. sınıf öğrencileri ile yazma etkinliklerinin kullanarak yürüttüğü çalışmasında, alt başarı grubundaki öğrencilerin ifadelerinin zamanla anlaşılırlığın arttığını ancak ifade etme biçimindeki eksikliklerin giderilemediğini ve ilgisiz konular hakkında açıklamalar yapmaya devam ettiklerini tespit etmiştir. Yalvaç (2019) ise cebir öğrenme alanında alt boyut olarak yazılı formal dili kullanma becerisinin yer aldığ 1 matematiksel dili kullanma becerilerini incelediği nitel araştırmasında, 8. sınıf öğrencilerinin matematiksel dili kullanımlarının yeterli düzeyde olmadığını tespit etmiştir.

Açıklamaların özellikleri teması altında incelenen, aynı konuda yapılan farklı açıklamalar ve açıklamalar ile matematiksel işlemler arasındaki tutarsızlıklar kodunda yazma uygulamalarının başarı seviyesi D ve C olan öğrencilere olumlu bir etki yaptığı söylenebilir. Yani yazma uygulaması bu başarı seviyesindeki öğrencilerin, yazdıkları üzerine düşünmelerini ve açıklamalarını zamanla içselleştirmelerini sağladığı belirtilebilir (King, Raposo ve Gimenez, 2016; Pugalee, 2001; Seto ve Meel, 2006). Çünkü ögrenciler başlangıçta yüzeysel olarak cevap vermekte daha sonra ise soru ile matematiksel bilgi arasında bağlantı kurarak cevaplar yazmaktadırlar. 
Phillis (2020) öğrencilerin kavrayamadıkları bir konu ile ilgili tutarlı yazı yazmalarının kolay olmayacağını, yazı yazmanın öğrencilerin düşüncelerini organize etmelerine yardımcı olacağını belirtmiştir. Dolayısıyla çalışmanın sonlarına doğru D ve C seviyesindeki öğrencilerin tutarsız, birbiri ile çelişen düşünceler yazmamaları, öğrencilerin konuları daha iyi anlamaya başladıklarını göstergesidir.

Açıklamalarını örnek vererek destekleme koduna göre, E seviyesindeki öğrencilerin yaptıkları açıklamalara hiç örnek yazmadıkları tespit edilmiştir. Diğer başarı seviyelerindeki özellikle C, B ve A seviyesindeki öğrencilerin uygulamalarda açıklama yazarken örnek verdikleri tespit edilmiştir. Shield ve Galbraith (1998) 8. sınıf öğrencileri ile yaptıkları yazma uygulamasında öğrencilerin yazılarında çok az bir gelişim gözleyebilmiştir. Öğrenciler başlangıçta nasıl yazıyorlarsa sonradan da aynı şekilde yazmışlardır. Örneğin başlangıçta fazla açıklama yapmayan öğrencinin sonradan da açıklamaları sınırlı olmaktadır. Başlangıçta örnek veremeyen öğrenci sonradan da örnek verememiştir. Ayrıca öğrenciler açıklayıcı yazma yerine daha çok matematiksel işlemleri yazmayı tercih etmişlerdir. Bu durum uygulamayı yapan öğretmenlerin yoğun yazma uygulaması yapmamasından kaynaklanmış olabilir. Çünkü araştırma süresi uzun olmasına rağmen yapılan yazma etkinlikleri sayısı fazla değildir. Halbuki gelişim olabilmesi için yoğun yazma uygulamalarının yapılması gereklidir. Çünkü Vygotsky’nin (1987) belirttiği gibi yazı yazma, sözlü konuşmadan her yönden farklıdır ve üst düzeyde soyutlama gerektirir. Dolayısıyla gelişim olabilmesi için yoğun ve uzun süreçli bir yazma uygulaması gerekir (Herrick, 2005; Özkan, 2019).

Akademik başarı seviyelerine göre ayrılan öğrencilerin ADPA'nın ikinci kategorisi olan matematiksel dil ve kelime kullanımı kısmından aldıkları puanların analizine göre B, C ve D seviyesinde olan öğrencilerin kullandıkları matematiksel dile ve kelimeye, yazma uygulamalarının olumlu etkisi olduğu belirtilebilir. Çalışmanın nitel bulgularına göre B, C ve D seviyesinde olan öğrenciler yazma uygulamaları sayesinde zamanla derste öğretilen matematiksel dili kullanmaya başlamışlardır. Bu durum, öğrencilerin yazma uygulamaları yapacak olması dolayısıyla derslerde kullanılan matematiksel kelime ve sembollere daha fazla dikkat etmelerinden ve öğretmenlerinin resmi dil kullanımını daha fazla isteyeceğini düşünmelerinden kaynaklanabilir. E seviyesindeki öğrencilerin ise resmi matematiksel dile dönüşüm olarak adlandırabileceğimiz bu dönüşümü gerçekleştirmede başarısız oldukları söylenebilir.

Bu temanın altındaki kodlardan ilki olan matematiksel sembol kullanımı ile ilgili kod ele alındığında, tüm seviye gruplarında yazma uygulamalarının her seviyedeki öğrencilerin sembol kullanımına katkı sağladığ belirtilebilir. Ancak kullanılan sembollerin yerinde ve doğru olarak kullanıldığı söylenemez. E ve D seviyesinde olan grupta sembol kullanımında yanlışlıklar vardır. Özellikle değişken sembolünün kullanımında ve işlemlerinde hatalar vardır. Başarı seviyesi arttıkça sembol kullanımının daha bilinçli yapıldığı, kullanılan sembollerin matematiksel olarak daha anlamlı olduğu belirtilebilir. Yeşildere (2010) sembollerin matematiksel açıklamaları destekleyen işaretler olduğunu, nasıl müzik notalarının doğru yazılması doğru melodiyi oluşturmak için yeterli değilse, matematiksel sembollerin ne anlama geldiğini kavramadan kullanılmasının da matematiksel düşünmeyi oluşturmak için yeterli olmayacağını belirtmiştir.

D seviyedeki öğrencilerden bazıları aynı konuda kullanılan kelimeleri, birbirlerinin yerine kullandıkları belirlenmiştir. Örneğin "kenar" yerine "köşe” kelimesini, "açı ölçüsü” yerine "açı" kelimesini, "kesir sayısı" yerine "rasyonel sayı" kelimesini, dik açı yerine "dik doğru” kelimesini vb. kelimeleri kullanmışlardır. Benzer olarak, Çalıkoğlu-Bali (2002) çalışmasında öğrencilerin kelimeleri birbirlerinin yerine kullandıklarını belirtmiştir. Yüzerler (2013) araştırmasında, 6. ve 7. sınıf öğrencilerinin öğrencilerin matematiksel dil kullanma becerilerinin eksik olduğunu, kavramları kullanırken ve anlatırken uygun ifadeleri seçemediklerini belirtmiştir. C ve B seviyesinde olan öğrencilerin çalışmanın başlarında yapılan uygulamalarda matematiksel kelimelerin kullanımına fazla dikkat etmediği ancak çalışmanın sonlarına doğru matematiksel kelimeleri daha dikkatli kullandıkları belirlenmiştir. Örneğin ilk uygulamalarda "doğrular paraleldir" yerine "açılar paraleldir", "kesişme” yerine "çakışma", "açı ölçüsü” yerine "açı”, "negatif tamsayılar” yerine, "eksi işaretli sayılar" vb. kelimelerini birbirinin yerine veya kendine özgü olarak kullanmalarına rağmen çalışmanın ilerleyen uygulamalarında bu tür kullanımlara rastlanmamıştır. Öğrencilerin çalışmanın sonlarında istenen düzeyde matematik terminolojisine uygun kelimeler yazdıkları belirlenmiştir. Ayrıca yazma uygulamalarının bu seviyedeki öğrencilerin matematiksel kelime kullanımını arttırdığı belirlenmiştir. Solomon ve O’Neill (1998) öğrencilerin kendi kelimelerini kullanmalarının, onları derste işlenen matematik konularına daha fazla odaklanmaya yönelteceğini belirtmiştir. Dolayısıyla yazma, tüm bilişsel seviyelerde olmasa bile öğrencilerin dersle daha fazla ilgilenmesini gerektirecektir. Matematik dilinin derslerde doğru kullanımı halinde; soyut kavramların öğrencilerin zihinlerinde daha kolay oluşabilmesi, yeni kavram ve bilgilere öğrencilerin kendilerinin ulaşabilmesi mümkün olacaktır.

Vygotsky (1987) yazma sebeplerinin konuşma sebeplerinden daha teorik olduğunu, yazma eyleminin konuşma eyleminden daha bilinçli ve kasti olan analitik davranışı gerektirdiğini belirtmiştir. Ayrıca çocuklar tarafından gerçekleştirilen bilişsel faaliyetleri yazmanın arttırdığını gözlemlemiş, yazma sürecinde içsel konuşmanın önemli bir rol oynadığını, özellikle öğrencilerin yazarak iletişim kurarken kelimelerin formal (gerçek) manasına dayandığını, bu yüzden aynı fikirleri sözle ifade etmek için kullanacakları kelime sayısından 
daha fazla kelime kullandıklarını ifade etmiştir (Albert, 2000). Markert (2019) öğrencilerin yeni matematik kavramları öğrenirken sözlü ve yazılı iletişim kurduklarında, kelimeleri matematiksel sembollere dönüştürebildiklerini ifade etmiştir. Ancak çalışmamızda bu durum her akademik başarı seviyesinde gerçekleşmemiştir.

Bu temanın şekil kullanma koduna göre yazma uygulamalarının E ve A seviyesinde olan öğrencilerin şekil çizimlerine olumlu katkı sağladığı söylenemez. A seviyesindeki öğrencilerin çalışmanın tüm süreçlerinde çizdiği şekiller konu ile ilgili ve yeterli düzeydedir. E seviyesindeki öğrencilerin çalışmanın sonlarında şekil çizimleri artmış görülebilir. Ancak bu yanıltıcıdır. Bu öğrencilerin çalışma sonlarındaki çizmiş olduğu şekiller konu ile ilişkilendirilmemiştir. Ayrıca başarı seviyesi ile öğrencilerin çizdikleri şekilleri konu ile ilişkilendirmeleri arasında doğrusal bir ilişki belirlenmiştir. Başarı seviyesi arttıkça çizilen şekiller, açıklamalar ile daha çok ilişkili ve matematiksel olarak daha anlamlıdır. Buradan başarı seviyesi ile matematiksel şekil kullanımı arasında doğrusal bir ilişki olduğu ve matematik kavramları ile ilgili düşüncelerini yazılı olarak ifade edemeyen, çözümlerini model, şekil veya tablo ile sunamayan E seviyesindeki öğrencilerin matematik iletişim becerisi açısından yetersiz oldukları belirtilebilir (Banes, 2017). Kramarski ve Mizrachi (2004) üst bilişsel düzeydeki öğrencilerin gerçek yaşam problemlerini çözmede olduğu kadar çözüm yöntemlerini yazmada da başarılı oldukları belirtmişlerdir. Bu sonuç çalışmamızın sonuçlarıyla benzerlik taşımaktadır. Dolayısıyla matematik iletişimi, üst düzey bilişsel becerilerin bir göstergesi olarak ele alınabilir ve matematik iletişim becerisiyle akademik başarı düzeyi arasında paralel bir ilişki olduğu söylenebilir.

Bu temanın son kodu olan farklı sembollerin kullanımının farkında olma koduna göre, E ve D seviyesinde olan öğrencilerin sembollerin farklı kullanımının farkında olmadıklarından bazı uygulamalara yanlış cevap verdikleri belirtilebilir. Ancak C, B ve A seviyesindeki öğrenciler farklı sembol kullanımının farkındadırlar. Örneğin B seviyesindeki öğrencilerden öğrenci çalışmanın sonlarındaki 22. uygulamasında “y, a" sembollerinin "x" sembolü ile aynı anlamda kullanılabileceğini belirtmiştir. Dolayısıyla başarı seviyesi ile farkında olma arasında doğru orantılı bir ilişkinin olduğu söylenebilir. Gürbüz ve Birgin (2008) buna benzer olarak öğrencilerin öğrenim seviyesi arttıkça rasyonel sayıların farklı gösterim şekilleriyle işlem yapma becerilerinin geliştiğini belirtmişlerdir. Ancak çalışmalarında öğrencilerin yazma uygulamalarının kullanılması ile farkındalıklarının artması yönünde bir ilişkiye bakmamışlardır.

Akademik başarılarına göre farklı seviyelere ayrılan öğrencilerin ADPA'nın üçüncü kategorisi olan matematiksel yapı ve hesaplamalar kısmından aldıkları puanlara göre, D ve C seviyesindeki öğrencilerin kurdukları algoritma ve yaptıkları matematiksel hesaplamalara yazma uygulamalarının olumlu etkisi olduğu belirtilebilir. Diğer başarı gruplarındaki öğrencilerde belirgin bir gelişim tespit edilememiştir. Davison ve Piarce (1990), öğretmenlerin yazma etkinliklerini sık ve sistematik şekilde (örneğin haftada en az bir defa) kullanırlarsa öğrenci performansının büyük ölçüde artacağını iddia etmektedirler. Ancak çalışmamızda bu durumum tüm başarı seviyelerindeki öğrenciler için geçerli olamayacağı belirlenmiştir. Benzer olarak Baxter ve arkadaşları (2005) akademik başarısı çok düşük olan 4 öğrenci ile yaptıkları talimatların yer aldığı günlük yazma çalışmalarında, öğrencilerin matematiksel başarılarına yazmanın katkı sağlamadığını tespit etmişlerdir.

Çalışmanın nitel bulguları kısmında oluşturulan son temadaki eksik, ilgisiz veya görsel olarak algılanan şekilde hesaplamalar yapma kodunda, D ve C seviyesindeki öğrencilerin hesaplama ve algoritmalarında olumlu bir gelişme belirlenmiştir. Reilly (2007) yazma uygulamasına katılan öğrencilerin, yazmanın yavaş gerçekleşen bir süreç olduğu için, matematik kavramlarını daha iyi anladıklarını ve işleme daha iyi odaklandıklarını belirtmiştir. Bundan dolayı yavaş gerçekleşen bu süreç içerisinde matematik performansları yüksek olmayan bu öğrencilerde bilişsel gelişim belirlenebilmiştir.

$\mathrm{Bu}$ koda göre E seviyesindeki öğrencilerde bir gelişim belirlenememesi, yazma uygulamalarının bu seviyedeki öğrencilerin hesaplama yapmalarını ve algoritma kurmalarını etkilemediğini göstermektedir. Bu seviyedeki öğrencilerin başarı seviyeleri çok düşük olduğundan, uygulamaları cevaplayacak ön bilgilerinin ve temel bilgilerinin yetersiz olduğu yorumu yapılabilir. Buradan öğrencilerin yazma uygulamalarını başarabilmeleri için ön bilgi düzeylerinin yeterli olması gerektiği belirtilebilir. Riward ve Straw (2000) yazma uygulamalarının sınıf ortamında etkili olmasının, öğrencilerin belirli temel bilgiye sahip olmalarına ve bunu akranlarıyla paylaşmalarına bağlı olduğunu belirtmişlerdir. Ayrıca Jaafar (2016) yazmanın, üst düzey bilişsel yeteneklerinin gelişmesine katkı sağlayacağını, bu öğrenme sürecinde kendini daha aktif hissetmesini sağlayacağını belirtmiştir. Çalışmamıza göre, öğrenme sürecinde tüm öğrenciler aktif olsalar bile üst düzey bilişsel yeteneklerinin geliştiğini söylemek mümkün değildir.

Bu temanın ikinci kodu olan farklı yapı ve hesaplama yöntemi geliştirebilme koduna göre, E seviyesindeki öğrencilerde bir öğrenci dışındaki hiçbir öğrencide farklı algoritma ve hesaplamaya rastlanmamıştır. Bu durum öğrencilerin yazma sürecine odaklanmalarını ve farklı çözüm yöntemleri geliştirmelerini engellemiş olabilir. Benzer şekilde D ve C seviyelerinde de sınırlı öğrenci farklı hesap ve algoritma kullanmasına rağmen, B seviyesindeki öğrencilerde özellikle çalışmanın orta ve son bölümlerinde yapılan çalışmalarda farklı algoritma ve hesaplama kullanımı görülmektedir. Bu durum uygulamaların öğrencilerin matematiğe karşı öz güvenlerini 
arttırmasından kaynaklanabilir. A seviyesindeki öğrencilerde ise çalışmanın genelinde farklı algoritma ve hesaplamalar kullandıkları belirlenmiştir. Kenyon (1989) problem çözme ve yazma arasındaki bağlantıyı araştırdığı çalışmasında, öğrencilerden düşüncelerini ve işlem süreçlerini yazmalarını istediğinde bir problemin farklı çözümlerini görebileceklerini belirtmiştir.

Son temanın son kodu olan sonucu değerlendirme (sonucun doğruluğunu ve mantıklılığını kontrol etme) koduna göre, tüm başarı seviyelerinden sadece iki öğrenci ( A ve C seviyelerinde) dişında hiçbir öğrenci sonucun doğruluğunu ve mantıklılığını düşünememiştir. Albert (2000) yazmanın problem çözümüne dahil edilmesinin, doğru cevaptan çok süreç içerisinde öğrencilerin odaklanabilmesine ve böylece cevapların çözümleri ve sonuçların ne derece makul ve mantıklı olduğunun değerlendirilmesini sağladığını belirtmiştir. Ancak çalışmada, öğrenciler süreç içerisine daha iyi odaklanabilmesine rağmen sonucun mantıklı olup olmadığını değerlendirmede güçlük çekmişlerdir. Bunun nedeni öğrencilere yazma için verilen sürenin az olmasından kaynaklanabilir. Öğrencilerin yazma uygulamalarını ders süresi içerisinde yetiştirmekte zorlandıkları hatta bazen teneffüste uygulamaya devam etmek zorunda kaldıkları olmuştur. Dolayısıyla, uygulamayı bitirdikten sonra tekrar yazdıklarını okuma ve üzerinde düşünme firsatı bulamamış olabilirler.

Tüm bulgular birlikte düşünüldüğünde, yazma uygulamalarının E ve A seviyesinde olan öğrencilerin bilişsel gelişimine anlamlı bir farklılık oluşturacak bir katkısının olmadığı, ancak bunların dışında kalan B, C ve D başarı seviyelerinin bilişsel gelişimlerine olumlu katkı sağladığı ve akademik başarı seviyelerine göre öğrencilerin yazılarında farklılık olduğu belirtilebilir. Bu bulgulardan ilki Knipper ve Dugger (2006) ile zit yöndedir. Yazarlar matematikte düşük başarılı öğrencilerin performanslarını arttırmada yazmanın kullanılabileceğini belirtmiştir. Ancak çalışmamızda başarı seviyesi çok düşük olan öğrencilerin bilişsel gelişmelerine katkısı sınırlıdır. Bu durum yazma uygulamalarının farklı akademik başarıya sahip öğrencilerden oluşan sınıfta uygulanması dolayısıyla hazırlanan bazı uygulamaların yapısı gereği başarısı çok düşük olan öğrencilerin seviyesinin üzerinde olmasından kaynaklanmış olabilir. Ayrıca Knipper ve Dugger (2006) çalışmalarında günlük yazmayı kullanmışlardır. Bu çalışmada ise günlük yerine ağırlıklı olarak açıklayıcı yazma çeşidi kullanılmıştır. Dolayısıyla bu farklılık kullanılan yazma çeşidinden de olabilir. Benzer olarak Roskin (2010) yazmanın matematik başarısına etkisini incelediği çalışmasında, yazma uygulamalarını rubrik kullanarak değerlendirmiştir. Matematik başarısı yüksek, orta ve düşük 4'er öğrencinin rubrik puanlarını karşılaştırdığında, başarısı düşük olan öğrenci grubunun rubrik puanlarındaki değişimin diğer gruptaki öğrencilere göre daha fazla olduğunu belirtmiştir. Burada seçilen 4'er öğrencinin grubu temsil etmede yetersiz kalacağı düşünülebilir. Ayrıca araştırmacı öğrencileri başarı seviyelerine ayırmada sadece bir yıl önce yapılan bir testten aldıkları puanlara göre gruplandırmıştır. Bu gruplandırma öğrencileri sevilerine göre ayırmak için yeterli olmayabilir.

E seviyesindeki öğrencilerin öğretmenden ve arkadaşlarından yardım alarak, mevcut gelişim seviyelerinin üzerine çıktıkları söylense bile bu öğrenciler yazma uygulamalarını kullanarak bilgilerini içselleştirememişlerdir. Açıklamalarının daha düzenli anlaşılır, net hale getirememişlerdir. Uygulama sırasında sosyal bir ortam içerisinde arkadaşlarından ve öğretmenlerinden yardım alan bu öğrenciler kendi matematik fikir ve düşüncelerini bağımsızca uygulayıp düzenlemede başarısız olmuşlardır. Dolayısıyla Albert’in (2000) belirttiği kendi kendini düzenleyebilen (self-regulatory), kendi kendine yardım edebilen (self-scalfolding) yeni bir bölge olan YÖU içinde bu öğrenciler matematiksel kavram ve fikirlerle ilgili düşüncelerini bağımsızca uygulayıp düzenleyemedikleri ve derin bir matematik anlayışına sahip olamadıkları belirtilebilir. Kısaca bu öğrenciler YÖE'den YÖU'ya geçiş yapamamışlardır. Yazma etkinliklerinin düşük seviyedeki öğrencilere daha fazla fayda sağladığını belirtmesine rağmen (Roskin, 2010), akademik başarısı çok düşük olan öğrencilerin kullanabileceği bir öğrenme yöntemi olmayabilir (Markert 2019). Benzer olarak Block (2005) çalışmasında yazma uygulamalarının tüm öğrenciler için bir öğretim yöntemi olamayacağını belirtmiştir. Yazar, çalışmasında öğrencileri başarı seviyesine göre incelememiş, ancak sınıfında yazma ve okuma uygulaması yapmasına rağmen gelişim göstermeyen öğrencilerin olduğunu belirtmiştir.

C seviyesindeki öğrencilerin çalışmanın başında ilgisiz açıklama yapmaları ancak daha sonra bunu yapmayıp, ayrıntılı açık ve anlaşılır açıklamalar yazmaları, bu öğrencilerin kendi kendilerini düzenleyebildikleri, kendi kendilerine yardım sağlayabildikleri bir alan olan YÖU'ya geçtiklerinin göstergesidir. Benzer olarak, $\mathrm{C}$ ve B seviyesindeki öğrenciler çalışmanın başlarında kendine özgü kelime ve semboller kullanmış olsa bile çalışmanın sonlarında kendine özgü kelime ve sembol kullanmamaları, çalışmanın sonuna doğru kelime ve şekil kullanımlarında artış olması bu seviyedeki öğrencilerin YÖE'den YÖU’ya geçtiklerinin delilidir. O'Connell ve arkadaşları (2005) fazla düşünmeden sözlü olarak verilen cevapların aksine, yazmanın öğrencilerin öğrendiklerini test etmelerine ve düşündüklerini kelimelerle düzenlemelerine olanak sağladığını, bu sayede yazmanın öğrencilerin kelimeler yoluyla düşündüklerini gözden geçirmelerine ve bunları düzeltmelerine imkan verdiğini belirtmiştir.

D seviyesindeki öğrencilerin çalışmanın başında, uygulamalara ilgisiz açıklama yapmaları, ilgisiz kelime kullanmaları veya matematiksel kelimeleri yanlış ifade etmeleri ancak uygulama sonlarına doğru matematiksel kelimeleri yerinde ve doğru kullanmaları, yazma uygulamalarının öğrencilerin kendi kendini düzenleyebildikleri bir alana geçiş yaptıklarının göstergesidir. Kısaca öğrenciler YÖE’den YÖU’ya geçiş yaptıkları belirtilebilir. 
Burada E seviyesindeki öğrenciler de çalışmanın başında ilgisiz açıklama yapmalarına rağmen çalışmanın sonlarında ilgisiz açıklama yapmamışlardır. Ama bu öğrenciler çalışmanın sonundaki uygulamalara açık ayrıntılı ve anlaşılır cevap yazmadıkları için, kendi kendilerini düzenleyebildikleri, kendi kendilerine yardım yapabilecekleri alan olan YÖE’den YÖU’ya geçişte başarılı olamadıkları söylenebilir.

Albert (2000), Bruner ve arkadaşlarının yazma sürecini kavram oluşturmanın temeli ve bilişsel gelişimin bir aracı olarak gördüklerini belirtmiştir. Böylece bir araç olarak yazma öğrencilerin düşünmesini destekler ve matematiksel düşünceler hakkındaki bilgilerini yapılandırmaya yardımcı olur. Öğrenciler kendi çözüm yollarını bulmaya, bunları kendi fikirleriyle ilişkilendirmeye kendi kendine problem çözme güveni geliştirmeye teşvik ettiğini belirtmiştir. Benzer olarak, Teledahl (2016) yazmanın öğrencilerin kendi kelimeleri ile bilgiyi tekrar yapılandırmalarını sağladığını, dolayısıyla öğrenmenin bir parçası olduğunu ifade etmiştir. Ancak yapılan bu çalışmada, yazma uygulamalarının farklı akademik başarıya sahip öğrencilerin tümü için aynı oranda katkı sağlamadığı belirlenmiştir. Kısaca, farklı akademik başarı seviyesindeki öğrencilerin bilişsel gelişimleri farklılık gösterdiği belirtilebilir. Yazma uygulamalarının özellikle orta ve civarındaki akademik başarı seviyesindeki öğrencilerin (B, C ve D) bilişsel gelişimine katkı sağladığı belirlenmiştir.

\section{5. Öneriler}

Yazma uygulamalarını derslerinde öğrenme aracı olarak kullanacak olan öğretmenlerin, en fazla verim alabilmeleri için öğrencilerin akademik başarı seviyelerinin çoğunlukla orta ve orta civarında olmasına dikkat etmesi önerilmektedir.

Yazma uygulamalarının öğrencilere olan birçok katkısı dikkate alındığında, ülkemizde kullanılan ders kitaplarının da matematik iletişimi destekleyecek özellikte olup olmadığının incelenmesi, varsa eksiklerinin giderilmesi önemlidir. Çünkü yazma uygulamalarının matematik iletişimine katkısı tek başına yeterli olmayabilir. Ayrıca matematik programlarında yazma uygulamalarının nasıl yapılacağına dair daha fazla bilgiye yer verilmelidir.

Öğrencilerin yazdıklarının üzerine daha çok düşünmesini, daha fazla odaklanmalarını, konuyu daha iyi anlamalarını sağlayan yazma uygulamalarının sınıflarda uygulanırken öğrencilerin hemen uyum sağlayamadığı, kolay olmayan bir süreç olduğu göz önünde bulundurularak, yazma uygulamalarının uzun bir zaman dilimine yayılarak ve sürekli olarak kullanılması önerilmektedir.

Yazma uygulamalarının sınıfta neler olup bitiğine dair öğretmene zengin ve değerli bilgiler vermektedir. Dolayısıyla kolay ve fazla maliyet gerektirmeyen yazma uygulaması konusunda, ilköğretim matematik öğretmenleri bilgilendirilerek sınıflarında etkili bir matematik öğretimi gerçekleştirmeleri sağlanabilir.

$\mathrm{Bu}$ araştırmada birçok yazma çeşidi içerisinden günlük yazma ve açıklayıcı yazma uygulamaları kullanılmıştır. Yazmanın diğer çeşitlerinin kullanıldığı araştırmalar yapılabilir. Yazma becerisi gelişiminin, matematik iletişimin diğer öğelerinden olan, matematiksel konuşma ve matematik okuryazarlığı üzerine de etkisi olabilir. Dolayısıyla matematiksel yazmanın, matematiksel okuryazarlık ve konuşma ile ilişkisini belirleyen çalışmaların yapılması önerilmektedir. 
Ek 1. Uygulama Etkinlik Örnekleri

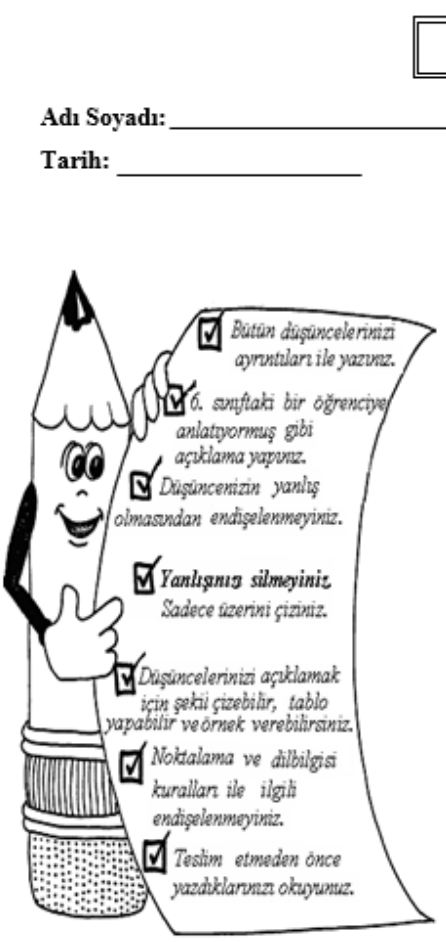

\section{Denklemler-3}

Adı Soyadr:

Tarih:

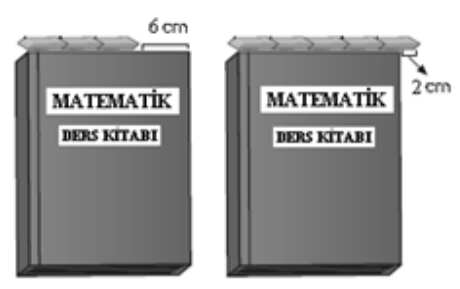

Ahmet dikdörtgen şeklindeki kitabının kısa kenarını silgisi ile ölçer. Ölçümde silgisini uç uca 3 kez eklediğinde $6 \mathrm{~cm}$ kaldı̆̆ını, 5 kez eklediğinde ise $2 \mathrm{~cm}$ fazla geldiğini görür. Bu kitabın kısa kenarınin kaç $\mathrm{cm}$ olduğunu bulmasında Ahmet'e yardımc1 olur musunuz?

\section{MATEMATIK GONLOGOM-3}

Adt Soyydr:

Tarih:
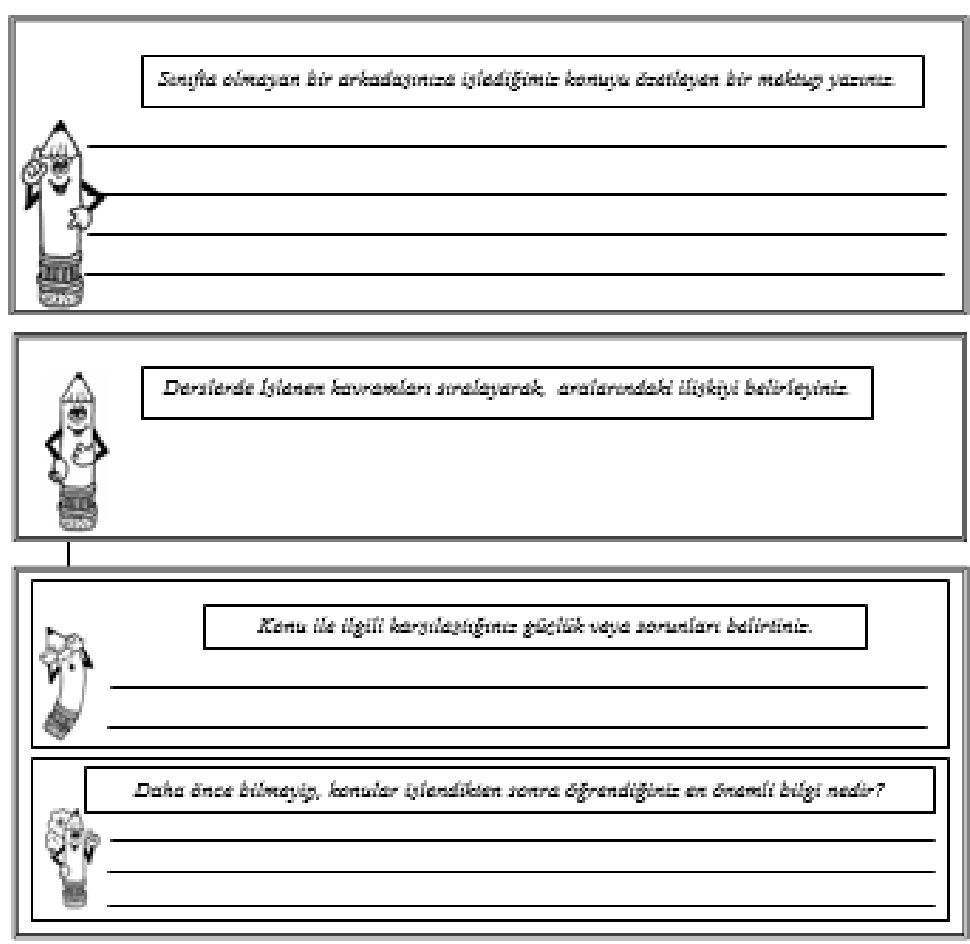


\section{Kaynaklar / References}

Akarsu-Yakar, E. \& Y1lmaz, S. (2017). Mathematical language skills of 7th grade students in the process of transforming the real life situation into a mathematical expression in algebra. Inonu University Journal of the Faculty of Education, 18(1), 292-310.

Akkuş, R., \& Darendeli, D. (2020). Research trends on writing-to-learn in mathematics in Turkey: Between 2005 and 2020. International Journal of Educational Studies in Mathematics, 7(1), 1-13.

Albert, L., R. (2000). Outside-in-inside-out: seventh-grade students' mathematical thought processes. Educational Studies in Mathematics, 41(2), 109-141.

Applebee, A. N. \& Langer, J. A. (2006). The state of writing instruction in American's schools: what existing data tell us. Albany: Center on English Learning \& Achievement, University at Albany, State University of New York.

Atasoy, E. (2005). Matematik ögretiminde yazmanın kullanılması (Yayımlanmamış yüksek lisans tezi). Karadeniz Teknik Üniversitesi, Fen Bilimleri Enstitüsü, Trabzon.

Baki, A. (2008). Kuramdan uygulamaya matematik eğitimi. Ankara: Harf Eğitim Yayınları.

Banes, L. C. (2017). "Explain your answer": Mathematical writing in linguistically diverse classrooms (Unpublished doctoral dissertation). California State University, the USA.

Baxter, J., Woodward, J., \& Olson, D. (2005). Writing in mathematics: An alternative form of communication for academically low-achieving students. Learning Disabilities Research \& Practice, 20(2), 119-135.

Beasley, K., \& Featherstone, H. (1995). The big old conversation, reflections on mathematical tasks and discourse (report no. 95-5), East Lansing, Michigan: National Center for Research on Teacher Learning.

Bellamy, D. (2017). College faculty members' perceptions of students' writing abilities (Unpublished doctoral dissertation). Walden University, the USA.

Block, N. E. (2005). How reading and writing influence student engagement and learning in the math classroom (Unpublished master's thesis). Pacific Lutheran University, the USA.

Bolte, L. A. (1999). Enhancing and assessing preservice teachers' integration and expression of mathematical knowledge. Journal of Mathematics Teacher Education, 2(2), 167-185.

Braine, G., \& McNaught, C. (2007). Adaptation of the 'Writing Across Curriculum' model to the Hong Kong context. In J. Liu (Ed.), English language leaching in China: New approaches, perspectives and standards (pp. 311-328). London: Continuum International Publishing.

Brandenburg, M. (2002). Advanced math? Write!. Educational Leadership, 60(3), 67-68.

Britton, J., Burgess, T., Martin, N., Mcleod, A., \& Rosen, H. (1975). The development of writing abilities (1118). London: Macmillan Education.

Burns, M. (2005). Looking at how students reason. Educational Leadership, 63(3), 26-31.

Burns, M. (1995). Writing in math class a resource for grades 2-8. CA: Math Solutions Publications.

Burns, M. (2004). Writing in math. Educational Leadership, 62(2), 30-32.

Burns, M., \& Silbey, R. (2001). Math journals boost real learning: How words can help your students work with numbers. Instructor, 110(7), 18-20.

Büyüköztürk, Ş. (2005). Sosyal bilimler için veri analizi. Ankara:PegemA Yayınları.

Colonnese, M. W., Amspaugh, C. M., LeMay, S., Evans, K., \& Field, K. (2018). Writing in the disciplines: How math fits into the equation. The Reading Teacher, 72, 379-387.

Cooley, L. (2002). Writing in calculus and reflective abstraction. Journal of Mathematical Behavior, 21(3), 255282.

Çalıkoğlu-Bali, G. (2002). Matematik öğretiminde dil ölçeği. Hacettepe Eğitim Fakültesi Dergisi, 23, 57-61.

Davison, D. M., \& Pearce, D. L. (1990). Perspectives on writing activities in the mathematics classroom. Mathematics Education Research Journal, 2(1), 15-22.

Demir, T. (2013). İlköğretim öğrencilerinin yaratıcı yazma becerileri ile yazma özyeterlik algısı ilişkisi üzerine bir çalı̧̧ma. Uluslararası Türkçe Edebiyat Kültür Eğitim Dergisi, 2(1), 84-114.

Demircioğlu, H., Argün, Z. ve Bulut S., (2010). Yazma tekniğinin kullanımına ilişkin ortaöğretim matematik öğretmen adaylarının görüşleri. C.Ü. Sosyal Bilimler Dergisi, 34(2), 40-46.

DeVries, R. (2000). Vygotsky, Piaget, and education: A reciprocal assimilation of theories and educational practices. New Ideas in Psychology, 18(2-3), 187-213.

DiBartolo, M. T. (2000). Writing opportunities as a teaching/learning tool in a college mathematics course (Unpublished Doctoral Dissertation). Columbia University, the USA.

Dur, Z. (2010). Öğrencilerin matematiksel dili hikaye yazma yoluyla iletişimde kullanabilme becerilerinin farklı değişkenlere göre incelenmesi (Yayımlanmamış yüksek lisans tezi). Hacettepe Üniversitesi, Sosyal Bilimler Enstitüsü, Ankara.

Ergün, M. ve Özsüer, S. (2006). Vygotsky'nin yeniden değerlendirilmesi. A.K.Ü. Sosyal Bilimler Dergisi, 8(2), 269-292.

Fluent, J. (2006). Writing and mathematical problem-solving: effects of writing activities on problem-solving skills of elementary students (Unpublished master dissertation). St. John Fisher College, New York. 
Frenkel, J. J. (2004). Writing use and its effectiveness on high school students' mathematics performance (Unpublished master's thesis). University of Wisconsin-Oshkosh, the USA.

Fulwiler, T. (1984). How well does writing across the curriculum work?. College English, 46(2), 113-125.

Fuqua, B. (1997). Exploring math journals. Childhood Education, 74(2), 73-77.

Furner, J., \& Duffy, M. (2002). Equity for all students in the new millennium: Disabling math anxiety. Intervention in School and Clinic, 38(2), 67-74.

Galbraith, D., \& Baaijen, V. (2018). The work of writing: Raiding the inarticulate. Educational Psychologist, 53(4), 238-257.

Gibson, M., \& Thomas, T. G. (2005). Quilting blocks: writing in the geometry classroom, Mathematics Teacher, 99(2), 108-111.

Graham, S., Kiuhara, S. A., \& MacKay, M. (2020). The effects of writing on learning in science, social studies, and mathematics: A meta-analysis. Review of Educational Research, 90(2), 179-226.

Gray, P., \& Feldman, J. (2004). Playing in the zone of proximal development: Qalities of self directed age mixing between adolascents and young children at a democratic school. American Journal of Education, $110(2), 193-200$.

Greenes, C., Ginsburg, H., \& Balfanz, R. (2004). Big maths for little kids. Early Childhood Research Quarterly, 19(1), 159-166.

Greer, A. R. (2010). Mathematical communication: A study of the impact expository writing in the mathematics curriculum has on student achievement (Unpublished doctoral dissertation). Capella University, Minneapolis.

Guce, I. K. (2018). The role of journal writing in senior high school students attitude toward mathematics. Internation Journal of Education and Researcher in Education, 7(2), 132-141.

Günel, M. (2009). Bilimsel süreç ve ilköğretim bilim eğitiminde öğrenme aracı olarak yazma. Elementary Education Online, 8(1), 200-211.

Güneş, F. (2013). Dil bilgisi öğretiminde yeni yaklaşımlar. Dil ve Edebiyat Eğitimi Dergisi, 2(7), 71-92.

Gürbüz, R. ve Birgin, O. (2008). Farklı öğrenim seviyesindeki öğrencilerin rasyonel sayıların farklı gösterim şekilleriyle işlem yapma performanslarının karşılaştırılması. Pamukkale Üniversitesi Eğitim Fakültesi Dergisi, 23(1), 85-94.

Hand, B., Yang, O. E. M. \& Bruxvoort, C. (2007). Using writing-to-learn science strategies to improve year 11 students' understandings of stoichiometry. International Journal of Science and Mathematics Education, $5(19), 125-143$

Herrick, C., J. (2005). Writing in the secondary mathematics classroom: research and resources (Unpublished master's thesis). State University of New York College, Cortland.

Hoffert, S.B. (2009). Mathematics: The universal language? Mathematics Teacher, 103(2), 130-139.

Hohenshell, L., Hand, B., \& Staker, J. (2004). Promoting conceptual understanding of biotechnology: Writing to a younger audience. The American Biology Teacher, 66(5), 333-338.

Ishii, D. K. (2003). First-Time teacher-researchers use writing in middle school mathematic instruction. The Mathematics Educator, 13(2), 38-46.

İpşiroğlu Z. (2006). Yaratıcı yazma çalışmalarında yazının işlevi. İstanbul: Morpa Yayıncılık.

Jaafar, R. (2016). Writing-to-learn activities to provoke deeper learning in calculus. Primus, 26(1), 67-82.

Johnson, J., \& Holcombe, M. (1993). Writing to learn in a content area. Clearing House, 66(3), 155 - 158.

Jurdak, M., \& Zein, R. A. (1998). The Effect of journal writing on achievement in and attitutes toward mathematics. School Science and Mathematics, 98(8), 412-419.

Kartalcı, S. (2018). Matematik öğretiminde yazma tekniği kullanımının üstbilişsel davranışlara etkisi (Yayımlanmamış yüksek lisans tezi). Sivas Cumhuriyet Üniversitesi, Eğitim Bilimleri Enstitüsü, Sivas.

Kasa, B. (2009). Yazma etkinliklerinin ilköğretim 1. kademe öğrencilerinin matematik başarılarına ve tutumlarına etkisi (Yayımlanmamış yüksek lisans tezi), Pamukkale Üniversitesi, Sosyal Bilimler Enstitüsü, Denizli.

Keathley, M. W. (2018). Connecting writing across the curriculum with global leadership:A qualitative study (Unpublished doctoral dissertation). Indiana Institute of Technology, United States.

Kenyon, R. (1989). Writing is problem solving. In P. Connolly \& T. Vilardi (Eds.), Writing to learn mathematics and science (pp. 73-87). New York: Teachers College Press.

Kerr, S. (1997). Why Vygotsky? The role of theoretical psychology in Russian education reform. Annual Meeting of the American Association for the Advancement of Slavic Studies. Seattle: University of Washington. Retrieved June 12, 2015, from http://faculty.washington.edu/stkerr/whylsv.html.

King, B. (1982). Using writing in the mathematics class: theory and practice. In C.W. Griffin (Ed.), New directions for teaching and learning: Teaching writing in all disciplines. (pp. 39-45). San Francisco: JosseyBass.

King, B., Raposo, D., \& Gimenez, M. (2016). Promoting student buy-in: Using writing to develop mathematical Understanding. Georgia Educational Researcher, 13(2), 31-52.

Klishis, L. A. (2003). The impact of student discourse and journal writing on the mathematics achievement of fifth grade students (Unpublished doctoral dissertation). West Virginia University, West Virginia. 
Knipper, K., \& Duggan, T. (2006). Writing to learn across the curriculum: Tools for comprehension in content area classes. The Reading Teacher, 59(5), 462-470.

Kramarski, B., \& Mizrachi, N. (2004). Enhancing mathematical literacy with the use of metacognitive guidance in forum discussion. Proceedings Of The 28th Conference Of The Internetional Group For The Psycology Of Mathematics Education, 3, 169-176.

Küçük, M. (2019). Yazma etkinliklerinin matematik ögretiminde problem çözme becerisine, tutum ve kayglya etkisi (Yayımlanmamış yüksek lisans tezi). Pamukkale Üniversitesi, Eğitim Bilimleri Enstitüsü, Denizli.

Lefler, S. (2006). Writing in a mathematics classroom: a form of communication and reflection. Action Research Projects:1-30. Retrieved July 15, 2010 from http://digitalcommons.unl.edu/mathmidactionresearch/58/.

Liedtke, W., \& Sales, J. (2001). Writing tasks that succeed. Mathematics Teaching In The Middle School, 6(6), 350-355.

Lim, L., \& Pugalee, D. K. (2006a). Using journal writing to explore "they communicate to learn mathematics and they learn to communicate mathematically". The Ontario Action Researcher, 7(2), 1-15.

Lim, L., \& Pugalee, D. K. (2006b). The effects of writing in a secondary applied mathematics class: A collaborative action research project. ARexpeditions, Retrieved November 23, 2007 from arexpeditions.montana.edu

Losike-Sedimo, N. (2018). Mother's influence on cognitive development: A cultural perspective. Advances in Social Sciences Research Journal, 5(1), 310-324.

Lynch, R. K. (2003). Implementing journal writing in the mathematics classroom: Cases of three middle school teachers (Unpublished doctoral dissertation). Indiana University, the USA.

Markert, L. P. (2019). Writing to learn in middle school mathematics: The effects on academic achievement (Unpublished doctoral dissertation). Mercer University, the USA.

Marlow, E. (2006). Writing in the mathematics curriculum. Journal of Instructional Psychology, 33(2), 120-123.

Mason, R., \& McFeetors, P. (2002). Interactive writing in mathematics class: Getting started. Mathematics Teacher, 95(7), 532-536.

McIntosh, M., \& Draper, R. (2001). Using learning logs in mathematics: Writing to learn. Mathematics Teacher, 94(7), 554-557.

McMillan, J., \& Schumacher, S. (2010). Research in education: Evidence-based inquiry. Boston MA: Pearson.

Milli Eğitim Bakanlığ $[\mathrm{MEB}]$. (2007). İlköğretim matematik dersi ögretim programı ve kılavuzu, Ankara: MEB Yayınlar1.

Meier, J., \& Rishel, T. (1998). Writing in the teaching and learning of mathematics (MAA Notes 48). Washington: The Mathematical Association of America.

Miller, L. D. (1991). Writing to learn mathematics. Mathematics Teacher, 84(7), 516-521.

Nagin, C., \& National Writing Project. (2003). Because writing matters: Improving student writing in our schools. San Francisco: Jossey Bass.

National Council of Teachers of Mathematics [NCTM]. (1989). Curriculum and evaluation standards for school mathematics. Reston: NCTM.

Nie, Y., Yeo S., M., \& Lau S. (2007). Application of generalizability theory in the investigation of the quality of journal writing in mathematics. Studies in Educational Evaluation, 33(3-4), 371-383.

Ntenza, S. P. (2006). İnvestigating forms of children's writing in grade 7 mathematics classrooms. Educational Studies in Mathematics, 61(3), 321-345.

O’Connel, S., Beamon, C., Beyea, J., Denvir, S., Dowdall, L., Friedland, N., \& Ward, J. (2005). Aiming for understanding: Lessons learned about writing in mathematics. Teaching Children Mathematics, 12(4), 192199.

Özkan, P. (2019). Öğrenme amaçlı yazma etkinliklerinin 6. sınıf ögrencilerinin alan ölçme konusundaki kavrayışlarına etkisi (Yayımlanmamış yüksek lisans tezi). Bolu Abant İzzet Baysal Üniversitesi, Eğitim Bilimleri Enstitüsü, Bolu.

Öztürk, F., Öztürk, B. ve Işık, A. (2016). Ortaokul matematik öğretmenlerinin yazmaya ve öğrenme amaçlı yazma aktivitelerine bakış açılarının belirlenmesi. Bayburt Eğitim Fakültesi Dergisi, 11(2), 306-327.

Phillis, C. (2020). Exploring teachers' use and perceptions of writing in the mathematics classroom: A case study at the secondary level (Unpublished doctoral dissertation). University of Massachusetts Lowell, USA.

Pugalee, D. K. (2004). A comparison of verbal and written descriptions of students' problem solving processes, Educational studies in mathematics, 55(1), 27-47.

Pugalee, D. K. (2001). Writing, mathematics and metacognition: Looking for connections through students' work in mathematical problem solving. School Science and Mathematics, 101(5), 236-245.

Quinn, R. J., \& Wilson, M. M. (1997). Writing in the mathematics classroom: Teachers beliefs and practices. The Clearing House, 71(1), 14-20.

Reilly, E. (2007). Writing to learn: A mixed-methods study (Unpublished doctoral dissertation). Indiana University of Pennsylvania, Pennsylvania.

Rivard, L. P., \& Straw, S. B. (2000). The Effect of talk and writing on learning science: An exploratory study. Science Education, 84(5), 566-593. 
Roskin, J. (2010). Writing and student achievement and engagement in mathematics classroom (Unpublished master's thesis). Caldwell College, New Jersey.

Senemoğlu, N. (2000). Gelişim ögrenme ve öğretim: Kuramdan uygulamaya. Ankara: Gazi Kitabevi.

Seto B., \& Meel, D. E. (2006). Writing in mathematics: Making it work. Primus, 16(3), 204-232.

Shanahan, T. (2006). Relations among oral language, reading, and writing development. In C.A. MacArthur, S. Graham, \& J. Fitzgerald (Eds.), Handbook of writing research (pp. 171-183). New York: Guilford.

Shield, M., \& Galbraith, P. (1998). The analysis of student expository writing in mathematics. Educational Studies in Mathematics, 36(1), 29-52.

Silver, E. A., \& Smith, M. S. (1996). Building discourse communities in mathematics classrooms: A worthwhile but challenging journey. In P. Elliott (Ed.), Communication in Mathematics (pp. 20-28). Reston: NCTM

Sipka, T. (1992). Writing in mathematics: A plethora of possibilities. In A. sterrett (Ed.), Using writing to teach mathematics (pp. 11-14). Washington DC: The Mathematical Association of America.

Smagorinsky, P. (1995). Constructing meaning in the disciplines: Reconceptualizing writing across the curriculum as composing across the curriculum. American Journal of Education, 103(2), 160-184.

Smagorinsky, P., \& Mayer, R. E. (2014). Learning to be literate. In R. K. Sawyer (Ed.), The Cambridge handbook of the learning sciences (pp. 605-625). Cambridge, UK: Cambridge University Press.

Solomon, Y., \& O’Neill, J. (1998). Mathematics and narrative. Language and Education, 12(3), 210-221.

Tanner, K. D. (2012). Promoting student metacognition. CBE-Life Sciences Education, 11, 113-120.

Teledahl, A. (2016). Knowledge and writing in school mathematics: A communicational approach. (Unpublished doctoral dissertation). Örebro University, Sweden.

Tekin-Aytaş, Ç. ve Uğurel, I. (2016). Bir matematik sınıfındaki yazma aktivitelerine dayalı öğretim uygulamasının öğrencilerin öğrenmeleri üzerindeki etkileri. Millî Ĕgitim Dergisi, 45(211), 113-146.

Uğurel, I., Tekin Ç., Yavuz S. ve Keçeli, S. (2009). Matematiğe yönelik tutumun belirlenmesinde alternatif bir araç: Teşvik edici yazma aktivitesi (teya). Bilim Eğitim ve Düşünce Dergisi, 9(1), 1-19.

Vygotsky, L. S. (1987). Thinking and speech. In R. W. Rieber, \& A. S. Carton (Eds.), The Collected Works of L. S. Vygotsky (Vol. 1), Problems of General Psychology (pp. 39-285). New York: Plenum Press.

Vygotsky, L. S. (1985). Düşünce ve dil (S. Koray, Çev.), İstanbul: Sistem Yayınları.

Williams, K. (2003). Writing about the problem-solving process to improve problem solving performance. Mathematics Teacher, 96(3), 185-187.

Witzel, B., \& Riccomini, P. (2007). Optimizing the math curriculum to meet the learning needs of students. Preventing School Failure, 52(1), 13-18.

Yalvaç, B., (2019). Sekizinci sınıf öğrencilerinin cebir öğrenme alanında matematiksel dili kullanma becerilerinin incelenmesi (Yayımlanmamış yüksek lisans tezi). Hacettepe Üniversitesi, Eğitim Bilimleri Enstitüsü, Ankara.

Yeşildere, S. (2010). İlköğretim matematik öğretmen adaylarının matematiksel alan dilini kullanma yeterlikleri. Boğaziçi Üniversitesi Eğitim Dergisi, 24(2), 61-70.

Yetim-Karaca, S. ve Ada, S. (2018). Öğrencilerin matematik dersine ve matematik öğretmenine yönelik algılarının metaforlar yardımıyla belirlenmesi. Kastamonu Education Journal, 26(3), 789-800.

Yıldırım, A. ve Simsek, H. (2005). Sosyal bilimlerde nitel araştırma yöntemleri, Ankara: Seçkin Yayıncılık.

Yılmaz, N. (2015). Cebir öğretiminde yazma etkinliklerini kullanmanın ortaokul 7. Sınıf öğrencilerinin başarılarına etkisi. Abant İzet Baysal Üniversitesi Ĕ̈itim Fakültesi Dergisi, 15(1), 357-376.

Yüzerler, S. (2013). 6. ve 7. Sınıf öğrencilerinin matematiksel dili kullanabilme becerileri (Yayımlanmamış yüksek lisans tezi). Necmettin Erbakan Üniversitesi, Eğitim Bilimleri Enstitüsü, Konya. 